\title{
The Impacts of Energy Development on Agricultural Land Values in North-Central West Virginia
}

Adama Sileye Warr

Follow this and additional works at: https://researchrepository.wvu.edu/etd

\section{Recommended Citation}

Warr, Adama Sileye, "The Impacts of Energy Development on Agricultural Land Values in North-Central West Virginia" (2018). Graduate Theses, Dissertations, and Problem Reports. 6916.

https://researchrepository.wvu.edu/etd/6916

This Thesis is protected by copyright and/or related rights. It has been brought to you by the The Research Repository @ WVU with permission from the rights-holder(s). You are free to use this Thesis in any way that is permitted by the copyright and related rights legislation that applies to your use. For other uses you must obtain permission from the rights-holder(s) directly, unless additional rights are indicated by a Creative Commons license in the record and/ or on the work itself. This Thesis has been accepted for inclusion in WVU Graduate Theses, Dissertations, and Problem Reports collection by an authorized administrator of The Research Repository @ WVU. For more information, please contact researchrepository@mail.wvu.edu. 


\title{
The Impacts of Energy Development on Agricultural land Values in North-Central West Virginia
}

\author{
Adama Sileye Warr \\ Thesis submitted to the \\ Davis College of Agriculture, Natural Resources and Design \\ at West Virginia University \\ in partial fulfillment of the requirements for the degree of \\ Master of Science in \\ Agricultural and Resource Economics \\ Alan R. Collins, Ph.D. Chair \\ Xiaoli Etienne, Ph.D. \\ Oleg Kucher, Ph.D.
}

Division of Resource Economics and Management

Morgantown, West Virginia

2018

Keywords: Impacts of Energy Development, Agricultural land values, North-Central WV Copyright 2018 Adama Warr 


\section{ABSTRACT \\ The Impacts of Energy Development on Agricultural land Values in North-Central West Virginia}

Adama Sileye Warr

This study presents an empirical model that explains the impact of energy development activities on agricultural land values in north-central West Virginia. Based on the methodology and the data description, seven different models (linear and logs) are estimated and the results are analyzed to understand the contributions of each energy variable used in the models to the overall values of farmlands. We have examined 311 parcel-level sales of farmlands in 16 counties in the north-central of the state of West Virginia from January 2013 to July 2016. The results suggest that the selected model is statistically different from zero (prob> $F=0.000$ ). Moreover, the model explains $40 \%$ in the variation of log per acre price. For the energy development variables, mineral rights transferred with agricultural land property have a positive, statistically significant (at the $10 \%$ level) coefficient in the model (as was expected). The more acres of mineral rights a parcel transfer contains, the higher its price should be compared to the one that has similar characteristics but not mineral rights.

Distance to active mining site contributes positively to total sale price (it has the expected sign). The further a parcel is from active mining site (mining area), the higher value it has compared to one that has similar characteristics, but is closer in distance to an active mining site. This coefficient is statistically significant at the 5\% level. If the distance of a parcel of agricultural land from active mining site increases by one mile, the value of the parcel increases by $2.18 \%$ keeping other variables constant.

For the non-energy variables, the coefficient for log appraised building value and log of number of acres in a tract variables have their expected signs, positive and negative, respectively. Each coefficient is statistically significant at the $1 \%$ level. In addition, their coefficients represent elasticities, meaning that a $1 \%$ increase in appraised building value causes the per acre price to increase by $0.08 \%$ and if total acres increases by $1 \%$, the price per acre decreases by $0.6 \%$, holding other variables constant.

Distance to town with population between 10,000 and 25,000 has a negative sign and it is statistically significant at $5 \%$. This is to say that the further a parcel of agricultural land is located from a city with a population between 10,000 and 25,000 , the less attractive it is to buyers. This coefficient has the expected sign. If the distance increases by 1 mile, the price per acre decreases by $1.8 \%$ holding other variables constant.

Distance to stream has a positive coefficient (the expected sign) and it is significant at $1 \%$. The further a parcel is from a stream, the more valuable it is compared to one with similar characteristics but in a closer distance to a stream. Probably, a parcel closer to a stream is highly likely to face flooding issues, which means that parcels that are located on areas of higher risks of flooding are less conducive to agricultural activities. Therefore, streams may cause a negative 
impact on agricultural land prices. If a distance of a parcel from a stream increases by $1 / 10$ of a mile its price increases by $13.2 \%$ holding other variables constant.

To assess the aggregate impact of the energy development on agricultural lands, one county, Brooke County, had the available data on all agricultural land parcels to conduct this analysis. Based upon the selected model results, an aggregate property value loss is estimated at over $\$ 2.4$ million for the owners of 176 parcels of farmland. This loss is based on an active coal mining site being located five miles from each parcel compared to the current distance. Five miles is double the average distance to an active coal mine for farmland parcels in Brooke County. While this study focused only on Brooke County, it is possible to see similar losses for property owners located near mining sites throughout the sixteen counties of north-central West Virginia. This analysis indicates property value losses from proximity to mining sites; however, these losses could be converted to property value gains if there was no mining sites or after these mining sites have been completed and remediated. There is a positive willingness to pay, as indicated by loss of property values, to have the mining site be move away from their locations. 


\section{ACKNOWLEDGEMENT}

I am deeply indebted to Dr. Alan R. Collins, committee chair and my major advisor, for his guidance, active involvement, and continuous assistance throughout my study. I would also like to thank my committee members, Dr. Xiaoli Etienne and Dr. Oleg Kucher, for their valuable insights, constructive criticism, motivation, and support.

I am appreciative of the opportunity to further my education at West Virginia University. I am also appreciative of the financial support from the Division of Resource Management and the dedicated faculty members and staff in Agricultural and Resource Economics Program who were extremely valuable in my education.

I also would like to express my special thanks to Jacqueline Strager who helped and provided me with the invaluable information (GIS) pertinent to this study.

I would like to acknowledge the love, encouragement, and prayers of my mother, Raki Demba Ba, my siblings, and my wife, Binta Oumar Ba.

Finally, I would like to thank my brother, Mamadou Warr, my great cousins, Amadou Ba, Moustapha Lemhamed Dicko, Maloum Aly Sall, and Abdoulaye Sall, my great friends, Ibrahima Bakayoko, Alassane Tall, and Abdallhi Fall, and all my friends who have encouraged me in difficult times during the course of my graduate studies.

This thesis is dedicated to the memory of my father, Thierno Sileye Warr. 


\section{TABLE OF CONTENTS}

$\begin{array}{ll}\text { Abstract } & \text { ii }\end{array}$

Acknowledgement iv

List of Tables $\quad$ vii

List of Figures $\quad$ ix

CHAPTER 1: INTRODUCTION

1.1 Introduction and Background Information 1

1.2 Objectives 5

CHAPTER 2: STUDY AREA

2.1 The Study area relative to the state of West Virginia 6

2.2 Geography and agricultural landscape $\quad 8$

$\begin{array}{ll}2.3 \text { Coal } & 10\end{array}$

2.4 Oil and Gas production 13

2.5 Wind Farms (wind energy) 13

2.6 Coverage of other important variables used in the study 13

\section{CHAPTER 3: LITTERATURE REVIEW}

3.1 Mineral Rights 16

$\begin{array}{ll}3.2 \text { Shale gas } & 19\end{array}$

$\begin{array}{ll}3.3 \text { Coal } & 20\end{array}$

3.4 Wind Farms 22

3.5 Agricultural Land Values 24

\section{CHAPTER 4: THEORETICAL ANALYSIS}

4.1 Approaches Used for Land Valuations 31

4.2 Theoretical Model of Agricultural land Values 32

\section{CHAPTER 5: METHODS}

5.1 The hedonic price method 36

5.2 The Empirical Model 36

5.3 Criteria used to compare models

5.4 Accounting for the Spatial Autocorrelation $\quad 40$

5.5 How the Aggregate Value is computed 40

\section{CHAPTER 6: THE DATA}

6.1 Separate sources of data 


\section{CHAPTER 7: RESULTS}

7.1 Presentation of spatial autocorrelation between the 311 parcels involved

7.1 Estimation Procedures

7.2 Results and Analysis

7.3 Aggregate Impact of Energy Development on Property Values

\section{CHAPTER 8: CONCLUSION AND POLICY RECOMMENDATIONS}

8.1 Summary $\quad 59$

8.2 Comparing our study results to other studies $\quad 62$

8.3 Limitations and Policy Recommendations 63

$\begin{array}{ll}\text { REFERENCES } & 65\end{array}$

$\begin{array}{lr}\text { APPENDIX } & 69\end{array}$

Appendix 1. Detailed Description of Agricultural Land Production in West Virginia 69 Appendix 2. GIS Part $\quad 75$

Appendix 3. Spatial Autocorrelation Report $\quad 81$

Appendix 4 Model \#1 $\quad 83$

Appendix 5. Model \# 2

Appendix 6. Model \#3 85

Appendix 7. Model \# $4 \quad 86$

Appendix 8. Model \#5 $\quad 87$

Appendix 9. Model \# $6 \quad 88$

Appendix 10. The Six models side by side (excluding M1) 89

Appendix 11. Appendix 11. The significant variables in Model \#4 and Model \#7 90

Appendix 12. The Study of model \#7 91 


\section{LIST OF TABLES}

Table 2.1. The Area of Farmland in Acres 9

Table 2.2. Agricultural Production 9

Table 2.3. 2015 Coal Production and Employment for the entire state 10

Table 2.4. 2015 Coal Production and Employment in the Study area 10

Table 2.5. 2016 Oil and Gas Production for the entire state 12

Table 2.6. 2016 Oil and Gas Production for the study area 12

Table 5.1 The Independent Variables and their Definitions and Units 42

Table 6.1 Summary Statistics 45

Table 7.1 The seven models and the energy variables 47

Table 7.2 The Adjusted R ${ }^{2}$, AIC, and SIC results 52

Table 7.3. Model \#7- Log Price per Acre 53

Appendix 1.1. Total acres of farms $\quad 69$

Appendix 1.2. Cropland and Pastureland 70

$\begin{array}{ll}\text { Appendix 1.3. Other Hay } & 71\end{array}$

Appendix 1.4. Corn for Grain $\quad 72$

Appendix 1.5. Soybeans $\quad 73$

Appendix 1.6. All Cattle and milk cows 2016

Appendix 3.1 Global Moran's I Summary $\quad 82$

Appendix 3.2 Dataset Information 182

Appendix 4 Model \#1 Regression output. Dependent Variable: Total Price 83

Appendix 5. Model \# 2 Regression output. Dependent Variable: Total Price 84

Appendix 6. Model \#3 Regression output. Dependent Variable: log Price 85

Appendix 7. Model \# 4 Regression output. Dependent Variable: log Price 86

Appendix 8. Model \#5 Regression output. Dependent Variable: Price per acre 87

Appendix 9. Model \# 6 Regression output. Dependent Variable: log Price per acre 88

Appendix 10. The Six models side by side (excluding M1) 89

Appendix 11. The significant variables in Model \#4 and Model \#7 90 
Appendix 12.1. Regression output for Model \#7. Dependent Variable: log Price per acre 


\section{LIST OF FIGURES}

Figure 1. U.S Total Energy Production (2000-2016) 1

$\begin{array}{ll}\text { Figure } 2 \text { Study Area } & 7\end{array}$

Figure 3 Geography of the Study Area $\quad 9$

Figure 4 Major Cities and Interstates in and around the Study Area 15

Figure 5 Brooke County and the Energy Development Sites 58

Appendix 12.2. Standardized residuals 92

Appendix 12.3. Potential Outliers For normalized residual squared 93

Appendix 12.4. Studentized residuals $\quad 94$

Appendix 12.8. Checking Homoscedasticity of Residuals 99 


\subsection{INTRODUCTION}

\subsection{Introduction and Background Information}

Schumacher (1977) has defined energy as "not just another commodity, but the precondition of all commodities, a basic factor equal with air, water, and earth." Energy is an imperative component of human life. A secure, adequate and available supply of energy is extremely critical for the maintainability of present day societies. The need for the provision of energy is growing quickly worldwide and the pattern is probably going to proceed in the future. (Varun, Prakash, and Bhat, 2009).

According to the U.S. Energy Information Administration (U.S. Department of Energy, 2017) most of the produced energy consists of fossil fuels. In 2000, the total U.S. energy production was about 72 quadrillion British thermal units (BTU); fossil fuels represented about $76.34 \%$ of the total production (Figure 1.a). Whereas, in 2016, the US total energy production was about 85 quadrillion BTUs. Fossil fuels dropped to about $72 \%$ of the total production with increasing renewable and nuclear sources of energy.

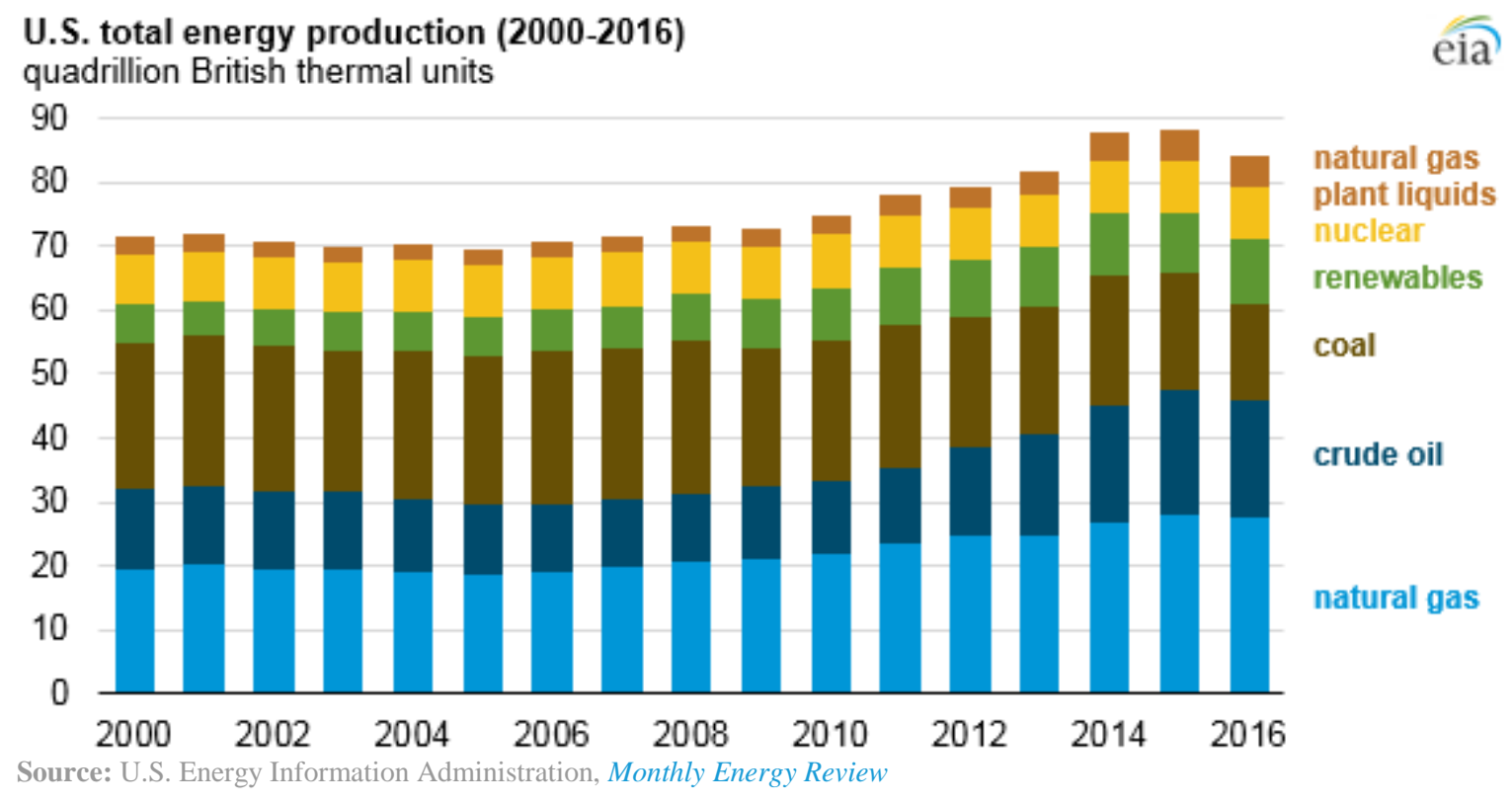

Figure 1. . U.S Total Energy Production (2000-2016) 
The vital part of energy is electricity. In the United States, in 2016, electricity generation was about 4.08 trillion kilowatt hours at utility-scale facilities; the majority of it came from fossil fuels (coal, natural gas, petroleum, and other gases), Nuclear energy and renewable energy sources represented $20 \%$ and $15 \%$ respectively. In addition, the major energy sources and percent shares of the U.S. electricity generation at utility-scale facilities for natural gas, coal, nuclear, and renewables represented about 34\%, 30\%, 20\%, and 15\% respectively. Moreover, wind accounted for about $6 \%$ of the total electricity generated from renewables.

The state of West Virginia is an important contributor to U.S. energy production. In 2013, West Virginia produced $4.6 \%$ of the total US production of energy, which makes it the fourth largest generator of energy resources in the nation. In addition, it produced $11 \%$ of total US production of coal to become the second in the nation. Moreover, West Virginia was the eighthlargest natural gas producer in the country in 2015 producing more than 1.3 trillion cubic feet of natural gas. In terms of electricity generation in the state in 2015 , coal, natural gas, and renewable energy sources contributed $94 \%, 1.8 \%$, and $3.7 \%$ respectively. However, for the renewable energy sources, hydroelectric power and wind energy source were the two main sources.

The national and state energy sectors traditionally relied on coal. Over the last 10 years, the unconventional natural gas and oil revolution driven by technological improvement led to substantial increase in natural gas and oil extraction. The development and utilization of these nonrenewable sources require the legal provision and the economic advances of the land usage for energy needs.

Mineral rights are very important for the production of energy. However, accessing the right to extract mineral could be the instigator of externalities that would be produced during 
extraction. The development of energy production land is at the expense of agricultural land, open space, and other land. Therefore, energy production influences land values. Energy development also can influence agricultural land values through the rights to minerals found underground. In addition, mineral rights may impact agricultural land values because of the US land ownership laws that stem from the English land ownership laws whereby minerals could be severed from the surface and sold separately (Fitzgerald, 2015). When minerals are not severed from the surface, farmlands are valued higher than when they are severed because of the potential extractability of the minerals by the energy companies, which buy the minerals from land owners for higher prices than the ones without minerals. Moreover, when minerals are being extracted, the extracting companies disturb the nearby agricultural land in order to gain access to their minerals, also the extraction sites are considered (at least from the environmental aspect) to be high sources of disamenities. Therefore, mineral rights influence agricultural land values, positively (when minerals are not severed) for some land owners and negatively (when minerals are severed) for others.

In the United States, private land ownership has regularly included mineral rights that can be transferred to another proprietor independently from the rest of bundle of property rights. Detachment of minerals from surface ownership of land is known as a split estate. Mineral rights proprietorship under common law (stemmed from English laws) is usually perceived as the dominant estate (Collins and Nkansah, 2015).

The fact that the owner of land could own mineral rights along with surface rights means that- he or she could split these two rights from one another. In many cases those mineral rights don't even transfer with the property. Therefore, if the mineral rights are not separated from the property, they could have a positive impact on the value of surface property. On the other hand, 
if they are separated (split estate) from the property, they could have a negative impact, which is the case for the most parts. For the most parts, mineral rights are not transferred.

Knowing what externalities are and what they would consist of from different energy production sources are important factors in order to fully understand the role of energy development on agricultural land values in north-central West Virginia. An external effect exists when someone's utility (or production) function contains a real variable whose value depends on the behavior of someone else, who does not take the effect of his or her behavior into account in his or her decision-making process (Cornes and Sandler, 1986).

Because mineral owners receive the benefits from natural gas extraction, mineral rights possession is likely to influence the value of agricultural land. Typically, agricultural lands with mineral rights are more valued than the ones without mineral rights. In addition, extracting minerals from a severed land causes a negative externality on the surface owner's land. Also, other impacts are the externalities of energy development on other people land. In the process of energy development, energy companies have to make their way to the energy sites. In doing so, they have to construct roads and dig for the underground pipes to be placed, and sometimes these activities are conducted on other people lands. In addition, noises that the energy companies' trucks make during extraction and the possibility of water contaminations from oil and gas leakages are valid negative externalities.

Each of the energy sources causes externalities in different ways and at different magnitudes. It is well established that the literature leaves little uncertainty that ecological and social problems in connection to coal mining and coal burning in coal fired power stations exist and are firmly connected to each other, and to negative health impacts. Therefore, it would impact agricultural production and the surface ownership. When producers and homeowners 
health is affected, production and ability to make payments on properties owned will be affected too (Morrice and Colagiuri, 2013).

Also, oil and gas activities are a noteworthy disturbance of the surface and have critical value implications for the surface estate proprietors (Baen, 1996). Moreover, wind generators can meddle with habitats, produce noise, aesthetic degradation, and impedance with bird flight. Large number of wind turbines can decrease wind-speeds and put pressure on ecosystems (Abbasi and Abbasi, 2000).

The ownership of mineral rights and location of energy development are important factors in knowing about who would benefit or lose from energy development in north-central West Virginia. Therefore, it is very important to understand what really explains the value of agricultural lands and to what extent mineral rights impact that value.

\subsection{Objectives:}

The main goal of this research is to investigate the overall impacts of energy development on agricultural land values within 16 counties located in the northern part of West Virginia. The three objectives are to:

1. Use hedonic modeling to quantify the important factors related to Mineral rights and externalities (the two mechanisms) from energy development that influence the values of agricultural lands,

2. Quantify the overall impact of energy development on agricultural land values, and

3. Analyze the mineral rights impact on the agricultural land values and provide policy recommendations. 


\subsection{STUDY AREA}

The study area was selected because it holds an important status to the state of West Virginia when it comes to energy and agricultural productions. It consists of the following sixteen counties in the north-central West Virginia; Ohio, Brooke, Marshall, Hancock, Harrison, Marion, Monongalia, Wood, Doddridge, Pleasants, Ritchie, Tyler, Wetzel, Barbour, Taylor, and Preston (Figure 1). According to the 2010 U.S. Census 560,008 people lived in the study area, which is approximately $30.22 \%$ of the total state population of $1,853,011$.

\subsection{The Study area relative to the state of West Virginia.}

The U.S. Census bureau report for July 1, 2016 estimates that the population of West Virginia has decreased by $1.2 \%$ since April 1, 2010 from 1,853,011 to 1,831,102. From 2011 to $2015,85 \%$ of individuals who were at least to 25 years old were high school graduates and $19.2 \%$ of this age group had earned at least a Bachelor's degree.

Housing units have increased from 881,917 to 886,640 during this period. The home ownership from 2011 to 2015 was at $72.5 \%$. The number of population per square mile in 2010 was 77.1. The median household income in 2015 was $\$ 41,751$. On average per capita income in 2015 was $\$ 23,450$. In addition, $17.9 \%$ of the population were living below poverty line.

For the study area, the US census bureau report for the same period estimates that the population of the area remained the same about 560,000. From 2011 to 2015, 87\% of individuals who were at least 25 years old were high school graduates and about $18 \%$ of this age group had earned at least a Bachelor's degree. Housing units have increased in the area from 260,784 to 261,659 from April 2010 to July 2016. The home ownership from 2011 to 2015 was $75.46 \%$. The number of population per square mile in 2010 was 150.65 . The median household income in 2015 was 42,024 and on average per capita income in 2015 was 22,790 . In addition, $16.6 \%$ of the population were living below poverty line. 


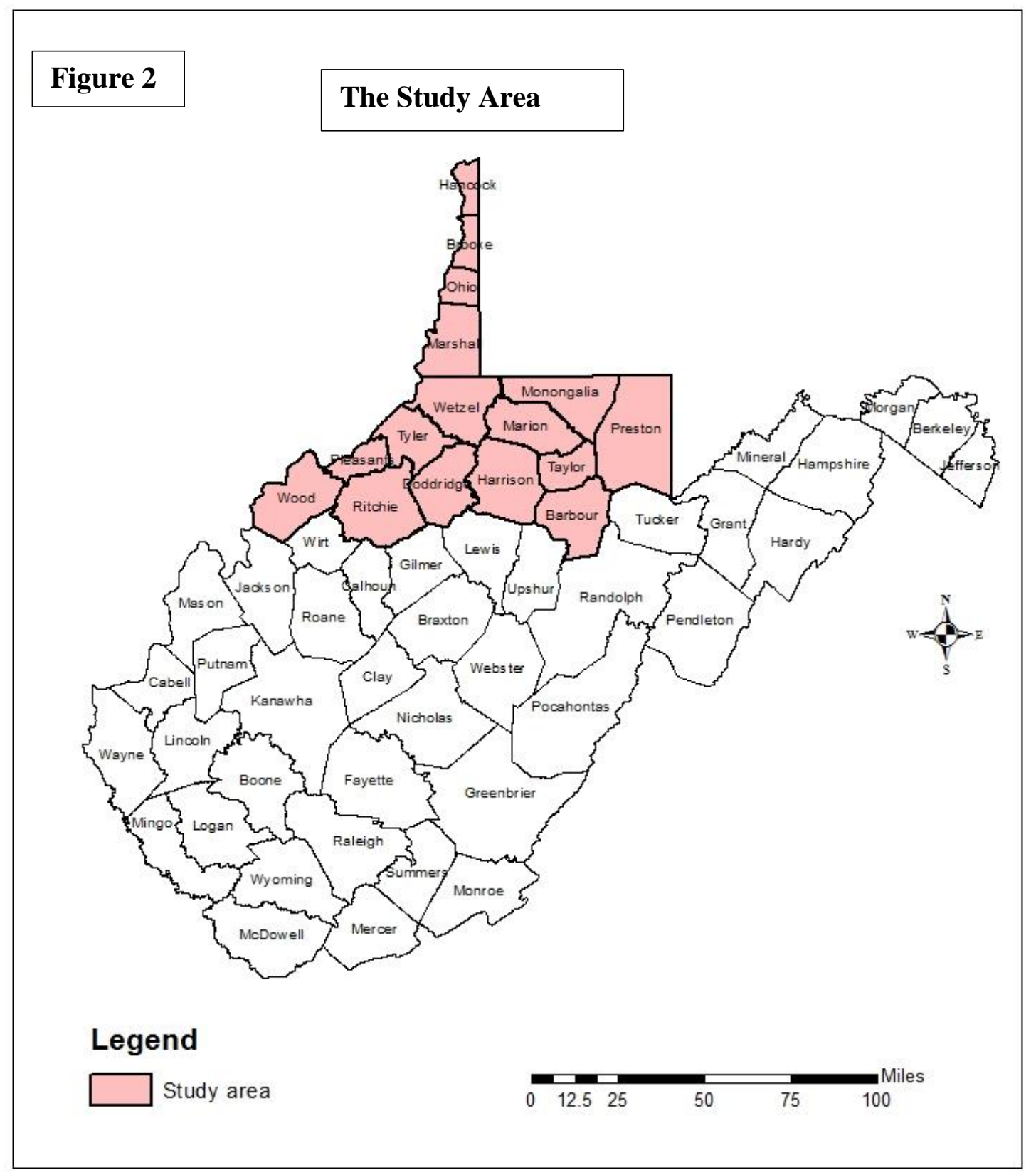

Figure 2....The Study Area 


\subsection{Geography and agricultural landscape.}

The land area of West Virginia is 24,038.21 square miles with different variation in slopes, elevation, longitude and latitude. The average elevation is about 1,500 feet. Most of West Virginia's land is covered with forest and crossed by rivers, lakes, streams and wetlands. The highest elevation is 4,861 and the lowest elevation is 240 feet.

In 2010, West Virginia had 23,000 farms with an area of 3.65 million acres. However, there was a decline of 2,100 farms over the period of six years with a total area of 50,000 acres.

For the study area, the land area is 4,712.94 square miles (according to the US census). It include the northern panhandle and north-central counties of the state, which are located in south of Western Pennsylvania and to the east of the state of Ohio. According to 2015 WV State Wildlife Action Plan (WVDNR, Wildlife Resources Section), fourteen of the counties in study area are in the geographic area of Allegheny Mountains and two counties are in the Western Allegheny Plateau (see Figure 2- Geography of the Study Area). The highest elevation of our data points (parcels in the study area) is 2837.93 feet and the lowest elevation is 652.89 feet. 


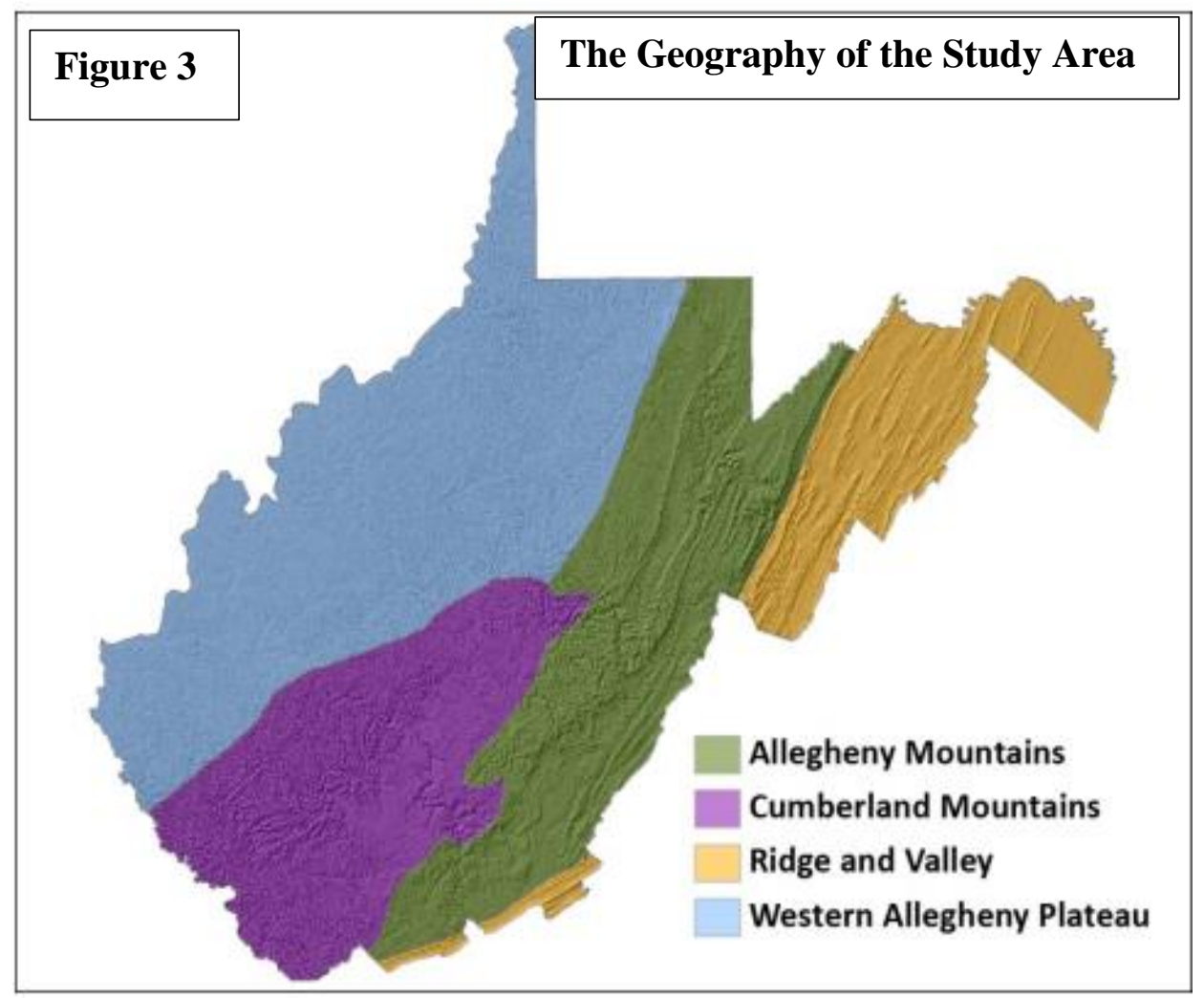

Figure 3... The Geography of the Study Area

According to West Virginia Annual Bulletin N0.47 of 2016, the agricultural lands and production statistics are summarized tables (2.1\& 2.2.)

Table 2.1. 2016 The Area of Farmland in Acres

\begin{tabular}{|c|c|c|c|c|c|}
\hline & Cropland & Pastureland & Other Hay & $\begin{array}{c}\text { Corn for } \\
\text { Grain }\end{array}$ & $\begin{array}{c}\text { Planted } \\
\text { Soybeans }\end{array}$ \\
\hline WV & 804,006 & $1,595,463$ & 570,000 & 50,000 & 27,000 \\
\hline Study Area & 242,575 & 435,038 & 186,800 & 5,300 & 500 \\
\hline \% of Total in Study Area & $\mathbf{3 0}$ & $\mathbf{2 7}$ & $\mathbf{3 3}$ & $\mathbf{1 1}$ & $\mathbf{2}$ \\
\hline
\end{tabular}

Table 2.2. 2016 Agricultural Production

\begin{tabular}{|c|c|c|c|c|c|}
\hline & $\begin{array}{c}\text { Other Hay } \\
\text { Production } \\
\text { (tons) }\end{array}$ & $\begin{array}{c}\text { Corn for Grain } \\
\text { Production } \\
\text { (bushels) }\end{array}$ & $\begin{array}{c}\text { Soybeans } \\
\text { Production } \\
\text { (bushels) }\end{array}$ & $\begin{array}{c}\text { Number of } \\
\text { Cattle }\end{array}$ & $\begin{array}{c}\text { Number } \\
\text { of Milk } \\
\text { Cows }\end{array}$ \\
\hline WV & 969,000 & $5,180,000$ & $1,248,000$ & 390,000 & 9,000 \\
\hline Study Area & 286,100 & 378,000 & 19,600 & 92,900 & 2,900 \\
\hline \% in Study Area & $\mathbf{3 0}$ & $\mathbf{7}$ & $\mathbf{2}$ & $\mathbf{2 4}$ & $\mathbf{3 2}$ \\
\hline
\end{tabular}


Because of the nature of West Virginia's landscape, the state has always been primarily a livestock producing state. Most of the agricultural production activities that go on in the study area are livestock, pasture, and crops productions. However, most of the cropland is used for hay production in support of animal production. Therefore, almost one fourth $(1 / 4)$ of cattle production and about one third (1/3) of milk cows of the state come from the study area. (For a detailed description of agricultural production in West Virginia, see Appendix 1).

Table 2.3. 2015 Coal Production and Employment for the Entire State

\begin{tabular}{|l|r|l|r|r|}
\hline State & Employees & $\begin{array}{l}\text { Surface } \\
\text { Tonnage }\end{array}$ & Underground Tonnage & Total Tonnage \\
\hline Total & 15,194 & $\mathbf{1 8 , 8 6 0 , 3 3 0}$ & $\mathbf{8 4 , 0 9 4 , 3 4 6}$ & $\mathbf{1 0 2 , 9 5 4 , 6 7 6}$ \\
\hline
\end{tabular}

Table 2.4. 2015 Coal Production and Employment in the Study Area

\begin{tabular}{|c|c|c|c|c|}
\hline County & Employees & Surface Tonnage & Underground Tonnage & Total Tonnage \\
\hline BARBOUR & 252 & & $1,840,735$ & $1,840,735$ \\
\hline HARRISON & 87 & 18,114 & 127,173 & 145,287 \\
\hline MARION & 1,165 & & $13,180,817$ & $13,180,817$ \\
\hline MARSHALL & 1,559 & & $16,363,955$ & $16,363,955$ \\
\hline MONONGALIA & 965 & 5,094 & $5,931,498$ & $5,936,592$ \\
\hline OHIO & 486 & & $10,654,593$ & $10,654,593$ \\
\hline TAYLOR & 438 & & $3,383,888$ & $3,383,888$ \\
\hline Total & $\mathbf{4 , 9 5 2}$ & $\mathbf{2 3 , 2 0 8}$ & $\mathbf{5 1 , 4 8 2 , 6 5 9}$ & $\mathbf{5 1 , 5 0 5 , 8 6 7}$ \\
\hline
\end{tabular}

\subsection{Coal}

According to West Virginia Office of Miners' Health, Safety, and Training, the total production of coal in 2015 in the state of West Virginia was 102,954,676 tons. 18,860,330 came from surface mining and 84,094,346 came from underground mining. 23,208 tons of the total surface mining came from the north-central West Virginia, which represented less than $1 \%$ of 
total production from surface mining. The total production of underground mining from the north-central West Virginia was 51,482,659 tons, which represented $62 \%$ of the total underground mining in the state. Moreover, the total coal production in the north-central West Virginia was $51,505,867$. Due to the recent decline of coal production in the southern and most of central counties of West Virginia in the last decade, the study area represents $50 \%$ of the coal production in the state in this period. (See summary in tables 2.3. \&2.4) 
Table 2.5. 2016 Oil and Gas Production for the Entire State

\begin{tabular}{|c|c|c|c|c|}
\hline State & $\begin{array}{c}\text { Total Production of } \\
\text { Natural Gas } \\
(\text { Mcf })\end{array}$ & Count Records & $\begin{array}{c}\text { Total } \\
\text { Production } \\
\text { Of Oil } \\
\text { (bbl) }\end{array}$ & Count Wells \\
Volume>0 & $\mathbf{1 , 3 4 7 , 6 1 9 , 4 3 0}$ & $\mathbf{4 8 , 1 6 7}$ & $\mathbf{6 , 4 4 1 , 7 4 1}$ & $\mathbf{7 , 4 1 8}$ \\
\hline
\end{tabular}

Table 2.6. 2016 Oil and Gas Production for the Study Area

\begin{tabular}{|c|c|c|c|c|}
\hline County & $\begin{array}{c}\text { Total } \\
\text { Production } \\
\text { Of Natural } \\
\text { Gas }\end{array}$ & $\begin{array}{l}\text { Count } \\
\text { Records }\end{array}$ & $\begin{array}{c}\text { Total Production } \\
\text { Of Oil }\end{array}$ & Count Wells \\
\hline & (Mcf) & Volume $>0$ & (bbl) & Volume >0 \\
\hline Barbour & 22962749 & 1779 & 4459 & 104 \\
\hline Brooke & 9004170 & 48 & 687112 & 48 \\
\hline Doddridge & 334486964 & 3606 & 490308 & 901 \\
\hline Hancock & 4548 & 3 & 541 & 2 \\
\hline Harrison & 128299402 & 3149 & 85773 & 323 \\
\hline Marion & 30052346 & 702 & 4299 & 29 \\
\hline Marshall & 143134484 & 406 & 1330133 & 211 \\
\hline $\begin{array}{c}\text { Monongali } \\
\text { a }\end{array}$ & 5168568 & 332 & 14063 & 70 \\
\hline Ohio & 49012863 & 96 & 1706515 & 94 \\
\hline Pleasants & 473820 & 588 & 11942 & 168 \\
\hline Preston & 2547303 & 158 & 61 & 4 \\
\hline Ritchie & 130742923 & 4446 & 892114 & 1119 \\
\hline Taylor & 36726606 & 541 & 357 & 10 \\
\hline Tyler & 120925392 & 756 & 513684 & 216 \\
\hline Wetzel & 208657074 & 1222 & 238723 & 416 \\
\hline Wood & 78400 & 133 & 8044 & 114 \\
\hline Total & $\begin{array}{c}1,222,277,61 \\
2\end{array}$ & 17,965 & $5,988,128$ & 3,829 \\
\hline $\begin{array}{c}\text { \% of the } \\
\text { Total }\end{array}$ & 0.9 & 0.37 & 0.93 & 0.52 \\
\hline
\end{tabular}




\subsection{Oil and Gas production}

According to West Virginia Geological and Economic Survey (WVGES, 2016), there were 48,167 gas wells that produced 1,347,619,430 thousand cubic feet (Mcf) of gas in the state of West Virginia. In addition, there were 7,418 oil wells that produced 6,441,741 barrels (bbl) of crude oil. Among the total production of gas and oil, 17,965 of gas wells with a production of $1,222,277,612$ thousand cubic feet and 3,829 oil wells with a production of 5,988,128 barrels of crude oil (bbl) came from the northern West Virginia. Both gas and oil productions in the northern West Virginia represented $91 \%$ and $93 \%$ of the state's total production of gas and oil respectively. (See summary in tables $2.5 \& 2.6$ ).

\subsection{Wind Farms (wind energy)}

According to West Virginia's Wind Projects (Operating and Permitted), there were two Operational Wind Projects: Mountaineer Wind Energy Center (FPL Energy - Tucker County) 66 MW with four permitted wind turbines in Preston County and AES Corp. (Laurel Mountain Barbour/Randolph County) $98 \mathrm{MW}$. In addition, the effect of 2,924 permitted wind turbines have been picked up by our study in our buffer zone of 50 miles radius, which covers parts of Pennsylvania, Ohio, and Maryland. The majority of permitted wind turbines in our study are located in Pennsylvania and Ohio. However, there are only four permitted wind turbines found in Preston County within our study area owned by Mountaineer wind energy.

\subsection{Coverage of other important variables used in the study}

There are 46,661 oil and gas wells within 10 miles radius, 6,319 active mining permits within 50 miles radius, 4,406 roads and Interstates within 50 miles radius, 4,636 acres with mineral rights, and 6319 streams within 10 miles buffer. In addition, there are sixteen (16) major cities with the size of 25,000 or more people within the distance of 50 miles radius from the 
study area (Figure 3). (See Appendix 2 for more details on how the data of this section were aggregated using the GIS tool). 


\section{Figure 4}

\section{Major Cities and Interstates in and around the Study area}

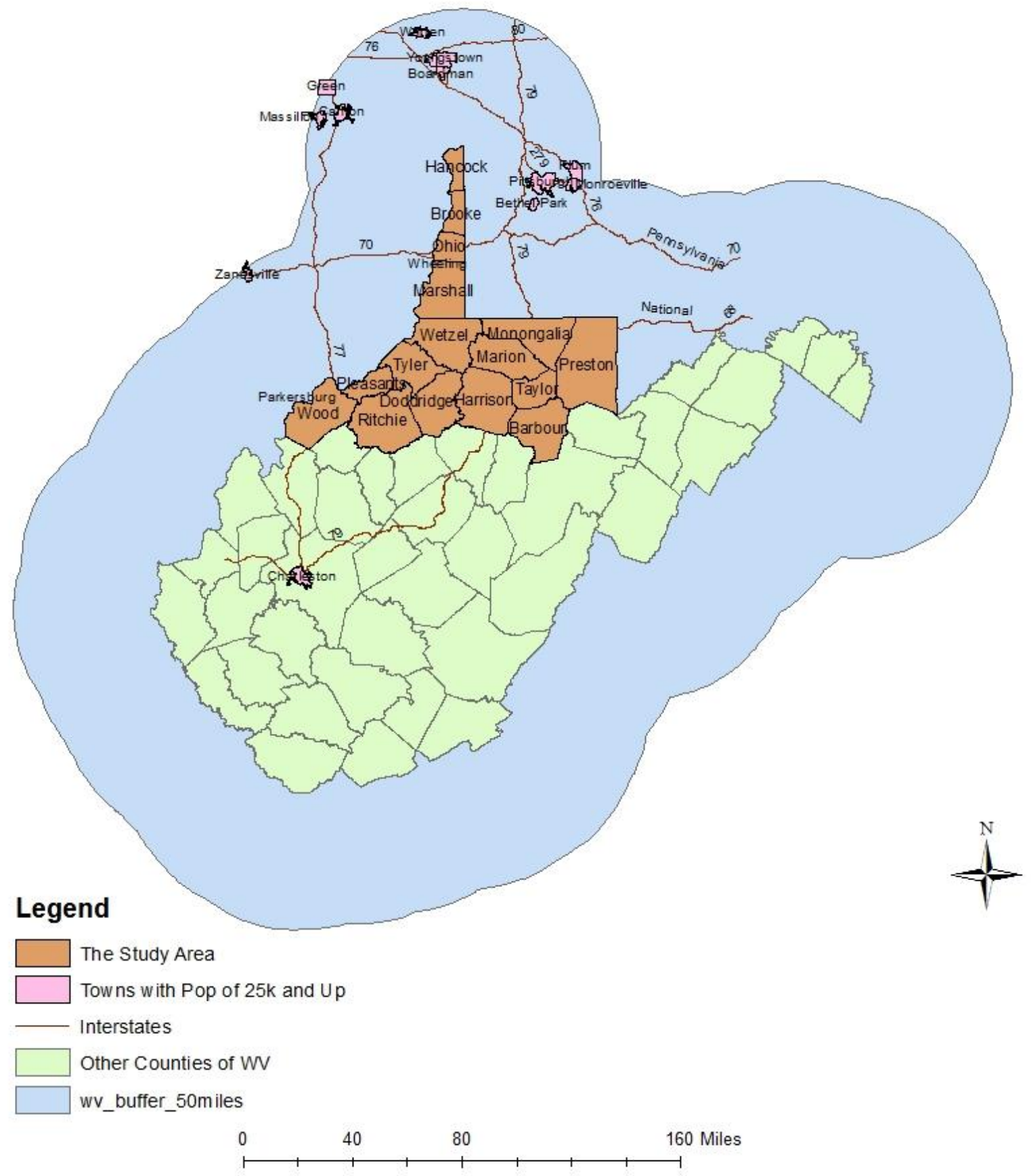

Figure 4... Major Cities and Interstates in and around the Study Area 


\subsection{LITERATURE REVIEW}

In the United States, a wide range of entities claim mineral rights: private people and firms, federal and state governments, and in federal trust for tribally possessed minerals. The provenance of mineral proprietorship for these diverse groups varies and is often specifically identified with the history of property claims in a specific area. Before 1908, the US government passed on rights to all minerals through homestead claims, with almost no acreage ineligible for claim. After that time, and particularly after 1916, mineral rights were never passed on to private proprietors and, instead, reserved by the government. States and tribes got minerals from government land grants. As a comparison, in most different nations their governments hold responsibility for subsurface minerals. (Fitzgerald, 2015). This review of literature emphasizes on mineral rights, shale gas development, coal, wind energy, and the factors that impact agricultural land values.

\subsection{Mineral Rights}

Property right is a right to own a piece of the nation's wealth. Property rights establishments underlie the performance and income dispersion in all economies. By characterizing the parameters for the utilization of rare resources and assigning the related rewards and expenses, the most viable system of property rights sets up motivating forces and time horizons for investment, production, and trade. Since property rights characterize the behavioral standards for the assignment and utilization of resources, it is conceivable to foresee how differences in property rights influence economic activity (Libecap, 1986). Owning mineral rights means to own an important source of energy in the US. However, the importance of mineral rights will never be understood until energy development, the means of developing it, and the competing sides of energy activities are clearly defined. 
Drilling in shale formation rich in oil and gas has brought about the U.S. to end up noticeably the worldwide pioneer in hydrocarbon production, yet the development has accompanied environmental and public infrastructure costs. However, resistance to taxing or regulating industries that produce negative externalities usually originates from convictions that such policies decrease investment and economic activity in general (Black, McCoy, and Weber, 2016).

The production of energy from fracking procedures will change energy costs. In any case, economic growth from energy related of the extraction of natural resources will probably extend to rural communities. Economic theory indicates that the shock created by the labor demand could create useful spillovers as well as negative outcomes. The positive spillovers are gotten through the multiplier procedure for jobs, wage, and so on. While the 'resource curse' suggests that a few businesses and residents could be hurt after some time through the extraction industry bidding up factor prices and swarming out economic activity (Komarek, 2015).

The current 'shale gas revolution' in the United States has made tremendous vulnerabilities for global gas markets that are probably going to hinder investment in gas - both conventional and unconventional - and in numerous renewables too. If the revolution proceeds in the US and reaches out to the rest of the world, energy consumers can foresee a future commanded by cheap gas. However, if it fails and the present buildup about shale gas demonstrates a fantasy, the world will confront genuine gas shortages in the medium term (Stevens, 2010).

The natural gas industry provides jobs for people living inside West Virginia as well as it hones corporate social duty by continuing to enhance and develop local communities in which they work. The natural gas industry participates in the success of nearby schools, service 
department, clubs, and altruistic associations all through the state of West Virginia (Higginbotham et al. 2010).

The access, recently gained, to the abundant natural gas could pull in gas concentrated manufacturing enterprises that would extend capacity in the Middle Atlantic and Northeast areas.

So also, abundant supplies of natural gas would empower electricity producers to cost effectively diminish greenhouse gas emissions since natural gas has impressively less carbon content than oil and coal. New industrial innovations prodded by the accessibility of rich natural gas and electricity would create extra jobs, production, and tax revenues. However, environmentalists and many concerned citizens are worried about their drinking water getting contaminated by the natural gas. (Considine, 2010).

Soeder and Kappel (2009) indicated that some important questions have been asked about drilling and its effect on water supply and wastewater disposal. Therefore, many state agencies have been careful about granting licenses, and few states have set bans on drilling until these issues are settles. In the meantime, gas companies, drillers, and landowners are anxious to push ahead and develop the resource. While the innovation of drilling directional boreholes, and the utilization of advanced hydraulic fracturing procedures to extract gas resources from tight rock have advanced over the previous couple of decades, the information about how this extraction may influence water resources has not kept pace. 


\subsection{Shale gas}

The 'shale gas revolution' alludes to a wonder that developed in terms of domestic gas supply in the United States. Shale gas is a part of what is depicted as 'unconventional gas'. The United States Geological Survey portrays conventional gas as gas sourced from discrete fields or pools confined in structural stratigraphical traps by the limit of gas and water. Unconventional gas is sourced from large areas existing freely of the water column. To make the description clear, a conventional gas well is drilled and the gas flows in commercial amounts. For unconventional gas, drilling is insufficient to produce commercial flow. Some other simulated jolt and unique recuperation procedures are required. The revolution happened because of two key innovations. These are horizontal drilling and hydraulic fracturing, where water, sand and chemicals are infused into the horizontal borehole of the well at high pressure to crack the shale rocks and discharge the gas (Stevens, 2012).

Marcellus Shale is one of the biggest petroleum gas holds in United States. The development and generation of this gas may radiate considerable quantities of oxides of nitrogen and unpredictable organic mixes. These discharges may have important effect in light of the fact that Marcellus development is happening near areas that have been assigned nonattainment for the ozone standard. Control technologies exist to greatly diminish these effects. PM2.5 emission are estimated to be unimportant in a local setting, however small amount of carbon emissions from diesel fueled machines might be critical (Roy, Adams, and Robinson, 2013). In addition, the extra natural gas generated from the Marcellus would drive the economy forward while diminishing ozone depleting substance emissions. In this way, the Marcellus could end up being Pennsylvania's secret weapon if policies that promote development are sought that would unleash the entrepreneurial soul of producers to develop this key national fortune (Considine et al. 2009). 
The wage spillover impacts in the Marcellus area seem, by all accounts, to be insignificant, which means there's little motivation at the county level to acquire present or potential future costs that might be related with gas activity. Therefore, localities may utilize policies that would enable natural gas extraction to move ahead, profiting landowners, while setting up some budgetary protections for the broader community (Paredes, Komarek, and Loveridge, 2015).

Between 2007 and 2013 the shale gas revolution was credited for an increase in welfare for natural gas users and producers of $\$ 48$ billion consistently every year, aside from more data are required on the degree and valuation of the environmental impacts of shale gas generation (Hausman and Kellogg, 2015). In addition, the monetary advantages of hydraulic fracturing are greatly known, however the ecological dangers remain a state of conflict. Dangers identified with probable groundwater contamination, seismic tremors, and other potential damages have brought up major issues about the hydraulic fracturing procedures, and in addition regulatory oversight of the oil and gas industry (Fershee, 2012).

\subsection{Coal}

Coal has been an important energy source in the United States for the $20^{\text {th }}$ century. From the late 1800s through 2008, U.S. coal production expanded alongside the nation's increasing interest for electricity. Nevertheless, U.S. coal production reached its peak in 2008 and is currently in decline. In 2015, coal production in the United States totaled 890 million short tons, 24 percent under its high of 1.172 billion short tons in 2008. Recent declines have been particularly sharp. In addition, the total U.S. weekly coal production fell by 39 percent between April 2015 and April.

The decrease was especially intense in Appalachia, where weekly coal production fell by 43 percent in that same year. Various factors are headed in these patterns: moderate growth in U.S. 
electricity demand; competition from natural gas at its lowest costs; declining fares; and environmental and clean energy policies from the state and federal governments. A few factors might be temporary, for example, reduced coal demand from power plants associated with moderately warm winter. Others, such as, low natural gas costs, will probably reflect long haul structural changes in the industry (Morris, 2016).

The clean air act contains a number of provisions restricting outflows of substances into the air. Air quality regulations, nevertheless, put far more prominent restrictions on combustion of coal than on coal generation. Emissions of air poisons from the mining procedure essentially include fugitive dust from surface and underground mines, discharges from uncontrolled flames at mines or inside mine reject piles, and particulate outflows from coal cleaning facilities. Control of fugitive dust includes covering transportation vehicles and wetting uncovered dust collections. The more noteworthy impact of clean air regulations on coal generation has been to decrease the demand for coal by making it less cost competitive with other different kinds of fuels. These outcomes from the gigantic cost of agreeing to the prerequisites for control technology to reduce emission from the combustion procedure (Powers, 1980).

Coal miners are losing their jobs in great numbers. Longstanding firms are filing for chapter 11 (bankruptcy), and retiree benefits are under risk. Some communities are facing difficult financial conditions, and numerous inhabitants in the coalfields have important healthcare needs that are not met. Moreover, even while coal enhanced countless lives by fueling affordable and dependable electricity, decades of coal production have battered landscapes and damaged waterways, and reclamation liabilities may not be funded enough. The government's policies to curb carbon dioxide emission, in the event that they are implemented as planned, will diminish coal utilization further, compounding all of these challenges that the industry faces (Morris, 2016). 
The coal business has assumed a noteworthy part in the way of life and history of the state of West Virginia, setting up an identity as the spine of the economy in the region. Nevertheless, as the mining procedure has turned out to be more mechanized, work has declined and risks have gotten higher, yet advocating for the industry proceeds (Blaacker, Woods, and Oliver, 2012).

\subsection{Wind Farms}

It is very well known that public perception about new concepts make a huge difference about how successful the new concept would be. Renewable energy in general had to go through same experiences. Six particular strands of research were distinguished, outlined and critiqued: public support for moving from conventional sources of energy to wind energy; parts of turbines related with negative perceptions; the effect of physical closeness to turbines; acceptance of wind farm in the future; the words, not in my back yard, as a clarification for negative perception; and, at last, the effect of local association on perception. Research across these strands was portrayed by opinion polls studies of general convictions and contextual analyses of impression of particular development. In both cases, research was divided and has failed to sufficiently clarify, as opposed to simply depict, perceptual procedures (Devine-Wright, 2005).

Renewable energy systems are good energy choices, in any case, the principle barrier is to reduce their cost to a competitive level. In practice, the higher renewable energy systems value should be repaid by government subsidies in order to help it to penetrate the market, or alternatively, conventional energy sources should be punished for not satisfying societal objectives, for instance through internalizing their external expenses. Renewable energy capacity development is often still connected to generous public support, yet advocated, e.g. to combat climate change but at the same time being a budgetary expenditure contending with other vital societal needs. In this way, seeing the impacts from energy policies past their energy impacts more 
towards industrial effects might be imperative to legitimize continued and even growing backing to meet the energy and climate challenges in the future (Lund, 2009).

During a period of growing worries over the increasing prices and long-term ecological effects of the utilization of non-renewable energy sources and nuclear energy, wind energy has turned into an undeniably vital element of the electrical power industry, generally on the grounds that it has been considered as being without emission and is bolstered by government endowments and tax credits. However, huge quantities of bats are dying at utility-scale wind energy generating facilities, particularly along forested ridgetops in the eastern United States. These fatalities raise worries about combined effects of suggested wind energy development on bats (Kunz et al. 2007).

Sources of energy based on oil, coal, and natural gas have turned out to be strong drivers of economic development, yet at same time harming to the earth and to human wellbeing. Keeping in mind, the social, economical and ecological impacts of sustainable power source system have been assessed. The uses of sustainable power source system, rather than, customary energy system, to control the social, economical and environmental issues have been analyzed. The outcomes demonstrate that the patterns of aggregate emission reduction in different years, which is exponentially expanding after the installation of sustainable power source system in remote areas (Akella, Saini, and Sharma, 2009).

A noteworthy preferred standpoint of wind energy with respect to nuclear, geothermal, fossil, and solar systems is that wind-based generation of power does not require cooling water. On the charge side wind generators can meddle with habitats, produce noise, aesthetic degradation, and impedance with bird flight. Large number of wind turbines can decrease wind-speeds and put pressure on ecosystems. Lakes that are downwind from the windmills may end up plainly hotter due to decreased dissipation from their surface. Soil moisture may likewise increase. Nevertheless, 
these effects may not be of great impacts aside from in certain sensitive regions and wind may turn out to be a standout amongst the most naturally benign sources of energy for power generation. In addition, when wind farms are located in agricultural land dispersed over the whole field, and hooked to a grid system, there will be small things about them that would be offensive. Hence, scattered wind energy systems do appear to be more environmentally benign than whatever other option source of energy (Abbasi and Abbasi, 2000).

Wind-generated electricity can be potentially an important drought-proof means of income for these farmland owners. Virtually, the greater part of the local vegetation has been removed from these zones, in this way making them not as much as appealing as destinations for migrating birds or as any sort of habitat for Galliformes (heavy-bodies ground feeding birds) (Kuvlesky et al., 2007). Also, numerous nations consider that wind, solar, and other inexhaustible energy innovations are the way to a clean energy future and put efforts to be the world's pioneer in creating, assembling, and utilizing these technologies. In addition, Interest in sustainable power source advancements requires a long-term planning viewpoint. Renewable energy can rival nonrenewable energy sources, however, it only can happen when prices are amortized over the operational lifetime of the venture (Dincer, 1999).

\subsection{Agricultural Land Values}

Estimating agricultural land improvements is important for individual agriculturists and policy makers. For example, a hedonic land value model was used to determine the value of erosion control and drainage utilizing data from North Carolina. The results indicated that land values are significantly affected by both potential erosivity and drainage requirements (Palmquist and Danielson, 1989). 
The market for land in West Virginia is heterogeneous with a blend of farming, forestry, industrial, and other land uses and impacts. Farm revenue and closeness to urban areas have been significant factors influencing the value of agricultural lands in the state. Additionally, the presence of huge public sector is significant because of the nearness of national forests, areas for wilderness, and state parks. Just around one-fifth of the state's area is in farms, while more than three-fourths is forested. Coal, oil, and natural gas production are very important industries that influence land use in the state. The state of West Virginia is principally rural and has no huge urban areas. However, it is surrounded by various vast metropolitan areas. For this reason, land values in every county have experienced numerous urban impacts (Shi, Phipps, and Colyer, 1997).

Hedonic model estimates uncovered that agricultural land was not resistant to the private housing bust; the segment of farmland value inferable from nearness to urban regions was practically sliced down the middle not long after the bust in 2009-2010. In any case, agricultural land prices remained generally stable in the 2000s, likely because of increased interest for agrarian products. The outcomes are robust to various suppositions about the structure of the unobserved spatial relationship (Zhang and Nickerson, 2008).

Farmland values can be fundamentally influenced by subsurface mineral rights, leasing activities, and oil and gas activities. Disturbance of the surface and other potential natural contemplations are vital factors in investment choices concerning the operation and long term venture potential of farmlands. There are potential clashes between mineral rights as the "dominant" estate, and the surface proprietor's point of view. However, there are possible approaches to lessen the negative impacts of oil and gas activities, both on particular properties and adjoining properties. Oil and gas activities are a noteworthy disturbance of the surface and have critical value implications for the surface estate proprietors (Baen, 1996). 
Numerous landowners and appraisers are not completely aware of the full effect of oil and gas exploration and production activities to a property's available and future market value. The initial step is to become more mindful of the oil and gas well development methods and procedures. The second step is to help landowners and oil companies to better arrange proposed facilities, and the third step is to appraise the present value ramifications of proposed wells from the standpoint of decreased revenue for the farmland; diminishment in the potential highest and best utilize; expanded presentation to ecological contamination; and consideration of wellbeing, welfare marks of disgrace, and other marketability components influencing the property (Baen, 1996).

From 1997 to 2013 in the areas where drilling activities were taking place, housing values in shale postal districts increased more than the value in non-shale postal districts amid peak development and less thereafter. Zillow Home Value index appreciated for typical house, the positive is greater than the negative up to 2013. Therefore, for a few (or most) occupants, it was conceivable that drilling caused disamenities. In addition, inside shale postal codes an additional well for every square kilometer associated with a $1.6 \%$ point decrease in appreciation over the study time frame (Weber, Burnett, and Xiarchos, 2014).

Few activities related with shale gas development are generally more permanent (pipelines, roads and related infrastructure, cushion zone, any chemicals staying in the groundwater or soil, gas leakage into drinking water) while others are generally more impermanent (nearby truck activity, potential odors, quakes). The more there are permanent features of unconventional shale gas development, probably, the more property values are going to be influenced and that the generally impermanent features will probably influence residents' utilization and satisfaction of the affected land (Lipscomb, Wang, and Kilpatrick, 2012). 
Shale gas development influences self-reported agricultural real estate values. Some farmers incorporate their oil and gas rights in the market estimation of their property. Furthermore, increase of the value of the land happens amid the leasing period, not when most drilling happens. The little or no extra increase in the drilling time frame may mirror a few contending forces. On one hand, investment of royalty payment in improvements to land or structures, greater local public revenues and overall greater interest for land ought to bring about appreciation amid the peak drilling stage. On the other hand, different factors could bring about depreciation: well productivity can decrease exponentially not long after being drilled and drilling can create ecological disamenities and influence the land's suitability for the utilizations that give it value (Weber and Hitaj, 2015).

There is no straight forward way to know what really influences agricultural land values. Nevertheless, there are some important techniques developed to approximate the factors that influence bundles that are not homogenous. One of the most important techniques is known as hedonic pricing technique. According to Sherwin Rosen, "Hedonic prices are defined as the implicit prices of attributes and are revealed to economic agents from observed prices of differentiated products and the specific amounts of characteristics associated with them. They constitute the empirical magnitudes explained by the model. Econometrically, implicit prices are estimated by the first-step regression analysis (product price regressed on characteristics) in the construction of the hedonic price indexes." (Rosen, 1974).

Hedonic Price Model was used as a standard economic model to indicate the financial impacts of changes in environmental quality close to private housing areas. The instinct behind this technique is as per the following, high-luxury places are both alluring spots to live and rare in supply. The owners of properties with access to these alluring properties discover their home prices 
offered up by contending purchasers willing to pay more to live close to high environmental amenities. Similarly, so as to get households to agree to live close to a less alluring condition, for instance, oil and gas well, families must be remunerated by lower house prices (Bennett and Loomis, 2015).

Agricultural land values are only partially explained by farm returns. Various nonagricultural properties of farmland add to the market value. Development potential is a critical determinant of market value. This fact might be utilized to keep on supporting endeavors to protect farmlands for farming through easements in situations where the coveted effect of the easement is to make farmland more reasonable for farmers. Also, different attributes, for example, nearness to golf courses and school grounds, and additionally higher median family earnings, were found to raise market values (Borchers, Ifft, and Kuethe, 2014).

To measure the factors that influence agricultural land values in north-central West Virginia, Hedonic pricing method is adequate for the purpose. Because it helps estimate a bundle (package) with different characteristics by estimating each characteristic separately. The Hedonic pricing technique depends on the start that market prices are identified with the characteristics of a property. For example, of two generally indistinguishable houses in generally indistinguishable neighborhoods, we would expect the one in the better school district to have a higher value. So also, we would expect the one with the more wonderful surrounding land uses to have a higher value. A distinction in prices of similar properties, however contrasting in access to environmental amenity, mirrors the economic value of the amenity. Land that utilizes related qualities may incorporate closeness to a recreation center, golf course, forest, or farmland, view of greenery, temperature and good quality air, and so forth. At the point when all these and other housing 
characteristics vary at the same time, the significance of each can be derived utilizing a multiple regression of property values on the different characteristics (Banzhaf and Jawahar, 2005).

Also, Hedonic model estimates uncovered that agricultural land was not resistant to the private housing bust; the segment of farmland value inferable from nearness to urban regions was practically sliced down the middle not long after the bust in 2009-2010. In any case, agricultural land prices remained generally stable in the 2000s, likely because of increased interest for agrarian products. The outcomes are robust to various suppositions about the structure of the unobserved spatial relationship (Zhang and Nickerson, 2008).

Land prices reflect the current use of the land, as well as its potential uses also. In a competitive market, the price of land will be the same as the discounted sum of expected net returns gotten from allocating the land to its most gainful use. That utilization clearly may change after some time. In the event that, for instance, farm production is currently the most gainful use, yet development for some other things is anticipated that would yield considerably more prominent net returns later on, at that point the present land cost ought to mirror the profits to both uses in a simple additive form (Plantinga, Lubowski, and Stavins, 2002).

The impact of Shale gas development on farmlands in the Barnett Shale (Texas) and the northeastern region of the Marcellus Shale (Pennsylvania and New York) was different. Even though Shale gas development caused appreciation of farmlands in both areas, nevertheless, the impact was considerably greater in the Marcellus, which points to more broad possession for gas and oil rights by surface owners. Double ownership of mineral rights in Barnett area is found in Marcellus area. In both zones, most appreciation of farmlands occurred exactly when land was leased for drilling, not when drilling and production were at their peak. They found that the effects changed by agricultural land type, which may mirror a connection between agricultural land types 
and the presence of mineral rights, in here, the ownership of oil and gas rights (Weber and Hitaj, 2015). 


\subsection{THEORETICAL ANALYSIS}

\subsection{Approaches Used for Land Valuations}

In West Virginia agricultural lands are appraised differently according to the types of structures on the lands (if there is any), different types of land uses (undeveloped, homesite, crop, pasture, forest, and wasteland), and on mineral rights (if they are not severed). Therefore, it is hypothesized that mineral rights, cropland, and pastureland contribute positively to the values of farmlands. Some studies have looked into what influences the farmland values in different areas in the country and they found that nonagricultural factors do influence the values of agricultural lands in the United States of America (Borchers et al., 2014).

Several important factors impact the market value of farmland. The potential profit per acre of land from production of food, fuel, and fiber are the most crucial forces behind agricultural land values. Expanded product yields made conceivable by the numerous innovative advances presented in the previous century have added to this. In many years, increases in farmland values have kept pace with or surpassed the rate of inflation in the United States, making ownership of farmland a decent support against inflation. This factor pulls in nonfarm investors, and agriculturists, into the farmland market. Interest rates and the returns from different investment also impact the demand for farmland and its prices. In certain areas, urbanization has significantly influenced land values, making some farming areas to be sold to developers for different purposes. Two main methods are used to appraise the farmland values, income capitalization and market data. Income capitalization method requires the selection of the discount rate, estimate of expected annual net income, and the computation of the present value of annuity as in the following equation (4.1):

$$
V=a / r
$$


where $a$ is the average (expected) annual return (rent); $r$ is the discount rate (annual interest rate), and $\mathrm{V}$ the estimated land value. Whereas, market data approach compares the tract that is being appraised to recently sold tracts and adjusting for the differences in factors found in different tracts (Kay, Edwards, and Duffy, 2016).

The most acknowledged theory of land valuation is that the value of land in a given use is the present discounted sum of net incomes or economic rents which the land is relied upon to yield over time. Along these lines, the estimation of land relies upon the discount rate utilized and the time allotment considered. Generally, the relationship is given as the following for an infinite time period, it is an expansion of model (4.1):

$$
V=\sum_{i=1}^{n}\left[\frac{a_{i}}{(1+r)^{t}}\right]
$$

Where $a_{i}$ is the expected annual rent, $\mathrm{r}$ is the annual interest rate, and $n$ is the number of years (Elad et. al, 1994). The action that determines what people pay in price is the market equilibrium, when markets enter into the supply of the productive services versus the demand for public services. However, the most important reason why individuals want to purchase land is because of the value of the productive services that would stem from the ownership of the land over time are what determine the value of land.

\subsection{Theoretical Model of Agricultural land Values}

One way to explain the value of a land is to look at the factors that influence the productive services. One of the most practical ways to explain the value of a land is to look at the factors that influence the productive services by using the hedonic model approach. Therefore, the theoretical model used in this research was Rosen's hedonic pricing model that takes a comprehensive approach in studying the impacts of energy development on agricultural land 
values in north-central West Virginia. Hedonic pricing is an empirical technique that is used to evaluate the prices of commodities that have different characteristics as in the following Rosen's model (4.3):

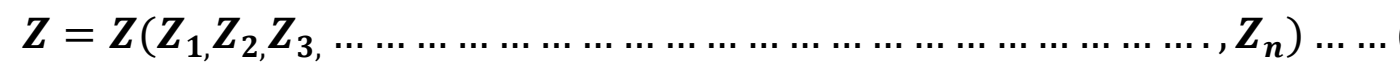

Where $\mathrm{Z}$ is the entire commodity. In this research, $\mathrm{Z}$ represents the parcels of farmland.

$Z_{1}, Z_{2}, Z_{3}, \ldots, Z_{n}$ represent the different on-site and off-site characteristics that describe the important economic components of a farmland parcel. $\boldsymbol{Z}_{\boldsymbol{i}}$ Could represent any characteristic. For example, $\boldsymbol{Z}_{\mathbf{1}}$ represents the structural characteristics, $\boldsymbol{Z}_{\mathbf{2}}$ represents the neighborhood characteristics, and $\boldsymbol{Z}_{\mathbf{3}}$ represents the environmental characteristics.

For the structural characteristics and the environmental characteristics, there are activities related to shale gas development that are more generally permanent (pipelines, roads and related infrastructure, cushion zone, any chemicals staying in the groundwater or soil, gas leakage into drinking water) while others are generally more impermanent (nearby truck activity, potential odors, quakes). The more permanent features of unconventional shale gas development, probably, the more property values are going to be influenced and that the generally impermanent features will probably influence residents' utilization and satisfaction of the affected land (Lipscomb, Wang, and Kilpatrick, 2012).

The overall value of a farmland is a combination of the individual values of each characteristic of the farmland. Therefore, the price of a farmland is reflected by the value of its individual parcel characteristics. In order to get the prices of farmlands the following functional form (hedonic model extended from Rosen's model) equation (4.4) is used as a general model:

$$
P(Z)=P\left(Z_{1}, Z_{2}, Z_{3}, \ldots \ldots \ldots \ldots \ldots \ldots \ldots \ldots \ldots \ldots \ldots \ldots \ldots \ldots \ldots \ldots \ldots, Z_{n}\right) \ldots \ldots(4
$$


$\boldsymbol{P}(\boldsymbol{Z})$ is the price of the parcel. It is a function of its characteristics $\left(\boldsymbol{Z}_{\boldsymbol{i}}{ }^{\prime}\right.$ 's), meaning the value of $\boldsymbol{Z}$ as measured by the price. Therefore, the marginal impact of $\boldsymbol{Z}_{\boldsymbol{i}}$ on the overall price of $\mathrm{Z}$ is the partial derivative of the total price as a function of $Z$ over the partial derivative of the $\boldsymbol{Z}_{\boldsymbol{i}}$ holding other characteristics of the parcel constant as:

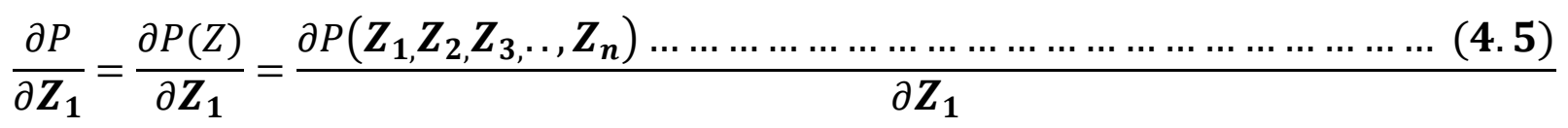

Other researchers have looked at numerous functional forms as in the following exponential functional form by Chicoine, (1981), which is an expansion (The refined Rosen' model) of equation (4.4) is:

$$
\operatorname{Price}=\beta_{0} Z_{1}^{\beta 1} \exp \left[\sum_{i=1}^{m} a i X i+\varepsilon\right]
$$

Other functional forms have been used in the literature including the linear functional form, Box-Cox transformation, the semi-log, log-log, the inverse semi-log, and the exponential. However, the non-liner is theoretically superior for hedonic models with externality impacts (Freeman, 2003).

To get the price of a commodity with heterogeneous characteristics, we use the equation (4.6) that was expanded from Rosen's model to explain agricultural land values. Given the availability of data at parcel level, it is possible to develop a hedonic model that captures the most important variables that influence the prices of farmland in north-central West Virginia, including the energy variables (mineral rights, active mining, oil and gas, and wind farms) among others.

Finally, by taking the natural log of both sides of the equation (4.6) the resultant becomes: 


$$
\ln \text { Price }=\beta_{0}+\beta 1 \ln Z_{1}+\sum_{i=1}^{m} \alpha \mathrm{iXi}+\varepsilon
$$

Price is the price of land per acre in dollars.

$Z_{1}$ is the size of the parcel in acres.

$m$ is the number of continuous variables.

$\boldsymbol{\varepsilon}$ is random error

$\boldsymbol{\beta}_{\mathbf{0}}$ is the intercept

$\mathrm{X}_{\mathrm{i}}$ is the continuous variables

$\alpha_{\mathrm{i}}$ is the coefficient of $\mathrm{X}_{\mathrm{i}}$. 


\subsection{METHODS}

\subsection{The hedonic price method}

Based on the energy activities around the study area, available parcel level data, and the study hypotheses, the study focuses on four energy development variables to evaluate the impacts of energy development on agricultural land values in north-central West Virginia.

The modeling of agricultural land prices in north-central West Virginia was conducted using hedonic pricing modeling technique. This technique is used when a commodity is not homogenous (more than one component make up the bundle). It is understood that each component has different weight on the overall price of the commodity. In this way, the technique could be applied to assess the prices of agricultural land in north-central West Virginia, since the agricultural lands are no different in this sense. By doing so, the model will show the impacts of energy variables on the overall price of the agricultural lands in north-central West Virginia. Even though the energy variables are not among the production variables of farmlands, they do influence the overall price of farmlands.

\subsection{The Empirical Model}

The empirical model (model 5.1) of our study is the same as model (4.7) that was driven from the theoretical model (4.6).

Lnprice $=\beta o+\beta 1 *$ lnacres $+\beta 2 * m r+\beta 3 *$ Activemine $+\beta 4 *$ DistWind $+\beta 5 *$ OilGaswell $+\cdots . .(5.1)$

LnPrice is natural log of price of land in dollars

Lnacres is natural log acres in acres

Activemine is distance to active mining site in miles

DistWind is distance to wind farm in miles.

OilGaswell is distance to Oil and Gas wells in miles. 
$\mathrm{mr}$ is the amount of minerals transferred with the parcel (it ranges between $0 \%$ and $100 \%$ ).

$\beta o$ is the intercept.

$\beta 1, \beta 2, \beta 3, \beta 4$, and $\beta 5$ are the coefficients of independents variables respectively

Regressing this hedonic model by using least-squares regression techniques would give us the coefficients of each variable included in the model. Each coefficient reflects the effect that its variable has on per acre of the agricultural land values in north-central West Virginia by holding other variables constant.

Economic theory and physical characteristics of the agricultural land dictate that these other variables to evaluate the prices of agricultural lands include: Land type variables-used by assessors (Homesite, Crops, Pasture, Forest, and Other), Surrounding features (Towns, Schools, Roads, Streams, Slope... etc.), and County dummy variables.

Ordinary least squares (OLS) regression procedure is used to estimate the models. Then, statistical tests are conducted using the results from the regression to verify if the assumptions held. In addition, measures of fit are going to be estimated (the F-test).

In order to get an unbiased and consistent estimates of the hedonic model above, the following assumptions for the error terms must hold (Wooldridge, 2003).

1. The mean of the random error is equals to zero $\left(\mathrm{E}\left[\varepsilon_{\mathrm{i}}\right]=0\right.$ for all i meaning that there is no misspecification or bias in the data generating process model.

2. The random error terms are uncorrelated $E\left[\varepsilon_{i} \varepsilon_{j}\right]=0$ for all $i \neq j$

3. The random error terms must be homoscedastic (must have a constant variance) for all $i$.

4. The random error must follow a normal distribution $\left(\varepsilon_{i} \sim \mathrm{N}\left(0, \sigma^{2}\right)\right)$. 
The following seven different models are going to be estimated: Total Price, Total Price, $\log$ Total Price, $\log$ Total Price, Per Acre Price, $\log$ Per Acre Price, and log Per Acre Price. The following tests are performed in order to select the model that is best fit for our study:

1- Checking for the Potential Outliers, two tests are conducted:

-One of the most the most important diagnostic graphs is provided by lvr2plot, leverage versus residual squared plot, it is a graph of leverage against the (normalized) residuals squared." It tests two things, outliers and the most influential observations.

-Stem and leaf plot for ti, Studentized residuals, Studentized residuals are a type of standardized residual that can be used to identify outliers. The stem and leaf displays some potential outliers. By sorting the data on residuals using the code (our data ID), we get the 10 largest and 10 smallest residuals. However, the ones that have values between -2 and +2 are not considered as alarming signs for outliers, therefore, they are not selected as potential outliers.

2- Checking for multicollinearity by using Variance inflation factor (Vif) test. When vif is greater or equals to 10 , we conclude that there is a multicollinearity between the variables involved.

3- Specification error (model misspecification). Two tests are conducted: -linktest: it indicates that if a regression is properly specified, we should not be able to find any additional independent variables that are significant. It creates two new variables, the variable of prediction,_hat, and the variable of squared prediction,_hatsq (it can only perform a model specification link test for single equation models). After the regression is done, the model is refit using these two variables (_hat and_hatsq) as predictors.

_hat is the predicted value and it should be significant. However, _hatsq shouldn't be significant given that the model is correctly specified. 
-ovtest performs a regression specification error test (RESET) similar to linktest but it is for omitted variables. It creates new variables based on the predictors then it refits the model using those new variables to find out if any of the variables would be significant. The Ramsey RESET test using powers of the fitted values of dependent variable has as: Ho (null hypothesis) as model has no omitted variables. Therefore, if we do not reject the null hypothesis, it means that the model has no omitted variables.

4- Checking for Homoscedasticity of Residuals. Two tests are performed:

-Fitted Values of Residuals plot: if Residuals and fitted values plot show a pattern of the data points getting a little narrower towards the left end, it means the possibility of heteroscedasticity exist. For a homoscedasticity, we should not see a uniform pattern.

-hettest is the Breusch-Pagan test. It tests the null hypothesis that the variance of the residuals is Homoscedastic (Constant variance). Therefore, if we failed to reject the null hypothesis, it means that it is heteroskdastic.

When heteroskedasticity exists, the robust standard error is run to fix it and it becomes the one that is reported for the study.

\subsection{Criteria used to compare models:}

Two steps are going to be used:

- $\quad$ if a model is misspecified will be eliminated from the selection process.

- $\quad$ Adj $\mathrm{R}^{2}$, Akaike information Criterion (AIC), and

Schwarz Information Criterion (SIC) are going to be used to compare between those model that are correctly specified. Higher Adj $\mathrm{R}^{2}$ and smaller AIC and SIC indicate that the model is best fit for the data in addition to models specifications and Homoscedasticity. 


\subsection{Accounting for the Spatial Autocorrelation}

To address the spatial concerns that a parcel in one location could impact the value of another parcel, the spatial autocorrelation (Global Moran's I) tool is going to be used to test it. The Moran's I tool is an inferential statistic; the results of the analysis are interpreted within the context of the null hypothesis. In our case, the null hypothesis is the per acre price of parcels involved are randomly distributed throughout the sixteen counties of north-central West Virginia. If we cannot reject the null hypothesis, it means that there is no correlation between the parcels data.

\subsection{How the Aggregate Value is computed}

The empirical model results will be used to assess the aggregate impact of energy development on agricultural lands in Brooke County. Brooke County (the only available data for the aggregate study) has provided its data but with fewer parcels of farmland (176) compared to some counties, for example, Preston County that has about 1,100 parcels of farmland. For Brooke County, GIS data are available for the entire county, which allows us to efficiently obtain property assessments to calculate the impacts of energy development on parcels of farmland in the county. The energy development is represented by the energy variables (distance to Active mining sites, distance to Oil\&Gas wells, distance to Wind turbines, and the average percent mineral rights transferred) in the model.

By applying the results from our property value model to all parcels of farmland in Brooke County, we will be able to assess the aggregate impact of the energy development on agricultural lands in the County. In order to do so, first we introduce the exponential function to both sides of our model to get the per acre value. Second, we plug into the model the values of the maximum 
distances of our energy variables (as the base) to parcels, to get the maximum per acre value. Third, we plug into the model the actual distance of the parcel to the closest energy development site, to get the parcel's actual per acre value. Forth, we calculate the difference between the parcel's actual per acre value, at its actual (closest) distance to the energy development sites (figure 4), compared with a projected per acre value located at the furthest distance there is from any energy development site within our buffer zones (50 miles radius around West Virginia for active mining sites and Wind turbines and 10 miles radius around the parcel centroid for the Oil and Gas (figure 3)).

The parcels per acre values are projected to rise when the distances are maximum. The maximum distances are: $24.18,94.97$, and 6.74 for the Active mining site, distance to Wind turbines, and Oil and gas wells respectively. To convert per acre value to Dollar amount, we just multiply the per acre values by the size (the number of acres a parcel has). Finally, to get the aggregate impact of energy development in Brooke County, we sum up the impact of energy development on all 176 parcels of farmland in Brooke County. 
Table 5.1. The Independent Variables and their Definitions and Units

\begin{tabular}{|c|c|}
\hline Variable & Definition and Units \\
\hline Acres & Total Acres \\
\hline Mineral Rights & Mineral Rights (ranges between 0 and 1) \\
\hline Appraised & Appraised Building Value in Dollars \\
\hline Home site & Number of acres of Home site \\
\hline Crop & number of acres of Crops \\
\hline Pasture & number of acres of Pasture \\
\hline Forest & number of acres of forest \\
\hline Other & $\begin{array}{l}\text { Commercial property, Undeveloped, and Wasteland areas in } \\
\text { acres }\end{array}$ \\
\hline Barbour & Dummy for Barbour County \\
\hline Brooke & Dummy for Brooke County \\
\hline Doddridge & Dummy for Doddridge County \\
\hline Hancock & Dummy for Hancock County \\
\hline Harrison & Dummy for Harrison County \\
\hline Marion & Dummy for Marion County \\
\hline Marshall & Dummy for Marshall County \\
\hline Monongalia & Dummy for Monongalia County \\
\hline Ohio & Dummy for Ohio County \\
\hline Pleasants & Dummy for Pleasants County \\
\hline Preston & Dummy for Preston County \\
\hline Ritchie & Dummy for Ritchie County \\
\hline Taylor & Dummy for Taylor County \\
\hline Tyler & Dummy for Tyler County \\
\hline Wetzel & Dummy for Wetzel County \\
\hline Wood & Dummy for Wood County \\
\hline Slope & the slope of the parcel in degrees \\
\hline Distance to town under $5 \mathrm{k}$ & Distance to town under 5,000 people in miles \\
\hline Distance to town $5 \& 10 \mathrm{k}$ & Distance to town with 5,000 to 10,000 people in miles \\
\hline Distance town10 \& 25k & Distance to town with 10,000 to 25,000 people in miles \\
\hline $\begin{array}{l}\text { Distance to town } 25 \mathrm{k} \& \\
\text { greater }\end{array}$ & $\begin{array}{l}\text { Distance to town with } 25,000 \text { and more than } 25,000 \text { people in } \\
\text { miles }\end{array}$ \\
\hline Distance to K 12 & Distance to $\mathrm{K}$ to 12 schools in miles \\
\hline Distance to Interstate & Distance to Interstate in miles \\
\hline Distance to US route & Distance to US routes in miles \\
\hline Distance to Active Mine & Distance to active mining area in miles \\
\hline Distance to Wind Turbine & Distance to wind farms in miles \\
\hline Distance to Oil \& Gas wells & Distance to oil and gas wells in miles \\
\hline Distance to Streams & Distance to actual streams in miles \\
\hline Elevation & the elevation in meters \\
\hline Log Price & Natural log of per acre price of land \\
\hline Log Size & Natural log of per acre size of land \\
\hline Log Appraised per Acre & Natural log for Appraised Per Acre \\
\hline
\end{tabular}




\subsection{THE DATA}

\subsection{Separate sources of data}

Agricultural land sales data from January 1, 2013 through 2016 were collected from multiple sources. Online information about deed transfers from County Assessor Offices was used to gather information on possible sales of interest. In addition, detailed information on all land sales was obtained from the Property Tax Division of the State Tax Department Office located in Clarksburg, WV. This detailed information included a breakdown of acreages for each sale by type of land (crop, pasture, and forest) along with the appraised value of structures on the property. Each County Assessor Office was visited to confirm information gathered from these sources or to directly gather sales information from deed transfers when online information was not available. Some County Assessors provided the sales listing reports on land sales that their office provided to the State Tax Department. Finally, property right transfers were linked to any mineral rights that may have been transferred along with the land parcel from the assessed value information contained in "Land Books" located at each County Assessor Office.

Typically, only information for sales over 20 acres was gathered. A subset (316) of sales transactions from sixteen counties in the north-central WV was selected as part of a larger effort to document the impact of mineral rights on agricultural land values in 31 counties in West Virginia.

The statistics on coal were collected from West Virginia Office of Miners' Health, Safety and Training (West Virginia Office of Miners' Health, Safety and Training, 2015), the statistics on oil and gas were collected from West Virginia's Geological and Economic Survey (WVGES, 2017), the agricultural statistics were collected from West Virginia's agriculture statistics (West 
Virginia field office, 2016), and the statistics on wind farms were collected from West Virginia's Wind Projects (Operating and Permitted).

There is an important part of the data for coal, oil and gas, and wind that was picked up by the 50 miles buffer zone, which includes some of the neighboring states, Pennsylvania, Ohio, and Maryland. The sources and procedures of collected data using the GIS tool are detailed in the GIS part (see Appendix 10) of the study in the appendices' section. The following data were gathered with the help of the GIS tool. The effect of 2,924 permitted wind turbines have been picked up by our study in our buffer zone of 50 miles radius, which covers parts of Pennsylvania, Ohio, and Maryland. The majority of permitted wind turbines in our study are located in Pennsylvania and Ohio. However, there are only four permitted wind turbines found in Preston County within our study area owned by Mountaineer wind energy. There are 46,661 oil and gas wells within 10 miles radius, 6,319 active mining permits within 50 miles radius, 4,406 roads and Interstates within 50 miles radius, 4,636 mineral rights acres, and 47,640 streams within 10 miles buffer. In addition, there are sixteen (16) major cities with the size of 25,000 or more people within the distance of 50 miles radius. Also, some of the variables have very small values meaning that they are very dense, like the wind farms variable. The wind farms variable includes per annual and intermittent streams. Therefore, its coefficient is too large. The maximum distance a parcel is away from streams is about 0.6 mile because streams and streams like are ubiquitous in this part of the state of West Virginia. 
Table 6.1. Summary Statistics of Agricultural Land Parcel Data, 311 Observations

\begin{tabular}{|c|c|c|c|c|c|}
\hline Variable \& (Units) & Obs & Mean & Std. Dev. & Min & Max \\
\hline Acres (acres) & 311 & 72.21229 & 50.86811 & 20 & 374 \\
\hline Price (Dollars) & 311 & 177998.7 & 131955.7 & 7500 & 850000 \\
\hline Mineral Rights (transferred, \%) & 311 & 0.173666 & 0.374353 & 0 & 1 \\
\hline Appraised (Dollars) & 311 & 47554.93 & 58813.08 & 1 & 354500 \\
\hline Homesite (acres) & 311 & 0.85209 & 0.635499 & 0 & 6 \\
\hline Crops (acres) & 311 & 12.06445 & 15.74316 & 0 & 96 \\
\hline Pasture (acres) & 311 & 18.70976 & 22.35842 & 0 & 191 \\
\hline Forest (acres) & 311 & 37.53632 & 37.81174 & 0 & 232.63 \\
\hline Other (acres) & 311 & 1.954212 & 5.236672 & 0 & 43.45 \\
\hline Barbour (Dummy) & 311 & 0.090032 & 0.286689 & 0 & 1 \\
\hline Brooke (Dummy) & 311 & 0.045016 & 0.207674 & 0 & 1 \\
\hline Doddridge (Dummy) & 311 & 0.083601 & 0.277235 & 0 & 1 \\
\hline Hancock (Dummy) & 311 & 0.028939 & 0.167905 & 0 & 1 \\
\hline Harrison (Dummy) & 311 & 0.073955 & 0.262119 & 0 & 1 \\
\hline Marion (Dummy) & 311 & 0.067524 & 0.251332 & 0 & 1 \\
\hline Marshall (Dummy) & 311 & 0.07074 & 0.256803 & 0 & 1 \\
\hline Monongalia (Dummy) & 311 & 0.041801 & 0.200456 & 0 & 1 \\
\hline Ohio (Dummy) & 311 & 0.019293 & 0.137773 & 0 & 1 \\
\hline Pleasants (Dummy) & 311 & 0.019293 & 0.137773 & 0 & 1 \\
\hline Preston (Dummy) & 311 & 0.102894 & 0.30431 & 0 & 1 \\
\hline Ritchie (Dummy) & 311 & 0.090032 & 0.286689 & 0 & 1 \\
\hline Taylor (Dummy) & 311 & 0.028939 & 0.167905 & 0 & 1 \\
\hline Tyler (Dummy) & 311 & 0.07074 & 0.256803 & 0 & 1 \\
\hline Wetzel (Dummy) & 311 & 0.067524 & 0.251332 & 0 & 1 \\
\hline Wood (Dummy) & 311 & 0.099679 & 0.300054 & 0 & 1 \\
\hline Slope (Degrees) & 311 & 11.20862 & 5.746226 & 1.21712 & 30.2106 \\
\hline Distance to town $5 \& 10 \mathrm{k}(\mathrm{mi})$ & 311 & 12.52566 & 7.85828 & 0 & 35.3708 \\
\hline Distance to town10 \& 25k (mi) & 311 & 17.36138 & 9.270472 & 0 & 38.77392 \\
\hline Dist to town $25 \mathrm{k} \&$ greater (mi) & 311 & 22.57091 & 11.73964 & 0 & 46.98559 \\
\hline Distance to K $12(\mathrm{mi})$ & 311 & 3.814809 & 2.014505 & 0.15029 & 9.580981 \\
\hline Distance to Interstate (mi) & 311 & 14.61829 & 8.973663 & 0.052725 & 32.0346 \\
\hline Distance to US route (mi) & 311 & 5.743923 & 4.33181 & 0.026363 & 20.12385 \\
\hline Distance to Active Mine (mi) & 311 & 7.947322 & 6.83844 & 0 & 24.18159 \\
\hline Distance to Wind Turbine (mi) & 311 & 44.64642 & 24.30618 & 1.694603 & 94.966 \\
\hline Distance to Oil\&Gas wells (mi) & 311 & 0.771181 & 1.044621 & 0.018641 & 6.741316 \\
\hline Distance to Streams (mi) & 311 & 0.130773 & 0.097694 & 0 & 0.593304 \\
\hline Percent of Crop (\%) & 311 & 17.67559 & 19.90746 & 0 & 91.30888 \\
\hline Percent of Pasture (\%) & 311 & 28.27423 & 24.65122 & 0 & 97.59557 \\
\hline Log Appraised (Dollars) & 311 & 8.184765 & 4.365442 & 0 & 12.77846 \\
\hline Mineral Rights Acres (\%) & 311 & 14.16381 & 40.61075 & 0 & 374 \\
\hline Log Acres (acres) & 311 & 4.093026 & 0.590102 & 2.995732 & 5.924256 \\
\hline Log Price (Dollars) & 311 & 11.81754 & 0.780083 & 8.922658 & 13.65299 \\
\hline Price per Acre (Dollars per acre) & 311 & 3168.067 & 2930.546 & 130.3668 & 22245.49 \\
\hline
\end{tabular}




\subsection{RESULTS}

\subsection{Presentation of spatial autocorrelation between the 311 parcels involved}

To address the spatial concerns that a parcel in one location could impact the price of another parcel, the spatial autocorrelation (Global Moran's I) tool was used to find out. The results of the analysis are interpreted within the context of the null hypothesis. The null hypothesis is the per acre price of parcels involved are randomly distributed throughout the sixteen counties of north-central West Virginia; the alternative hypothesis is the per acre price of parcels involved are not randomly distributed. The results indicate that the P-value $=0.646$. Therefore, we could not reject the null hypothesis, which means that the per acre price is randomly distributed among the parcels involved in the sixteen counties of north-central of the state of West Virginia. The spatial processes promoting the observed pattern of per acre price for the 311 parcels in the study area is random chance. (See Moran's I output in appendix 3).

\subsection{Estimation Procedures}

The purpose of this research is to evaluate the impacts of energy development on agricultural land values in north-central West Virginia. Based on the methodology and the data description, seven different models are estimated and the results are analyzed and explained in here. Total Price, Total Price, ln Total Price, ln Total Price, Per Acre Price, ln Per Acre, and ln Per Acre Price. Table 7.1 summarizes the seven models, the energy variables' impacts, and model specifications test results. 
Table 7.1. The Seven models and the Energy Variables

\begin{tabular}{|c|c|c|c|c|c|c|c|}
\hline $\begin{array}{c}\text { Dependent } \\
\text { Variable } \\
\end{array}$ & $\begin{array}{c}\text { Price } \\
\text { M1 }\end{array}$ & $\begin{array}{c}\text { Price } \\
\text { M2 }\end{array}$ & $\begin{array}{c}\text { Ln } \\
\text { Price } \\
\text { M3 } \\
\end{array}$ & $\begin{array}{l}\text { Ln } \\
\text { Price } \\
\text { M4 }\end{array}$ & $\begin{array}{c}\text { Price } \\
\text { per } \\
\text { acre } \\
\text { M5 } \\
\end{array}$ & $\begin{array}{c}\text { Ln } \\
\text { price } \\
\text { per acre } \\
\text { M6 } \\
\end{array}$ & $\begin{array}{c}\text { Ln } \\
\text { Price } \\
\text { per acre } \\
\text { M7 } \\
\end{array}$ \\
\hline $\begin{array}{c}\text { MR/ } \\
\text { MR*ACRES }\end{array}$ & & & $(+)^{*}$ & $(+)^{*}$ & & $(+)^{*}$ & $(+)^{*}$ \\
\hline $\begin{array}{l}\text { ACTIVE } \\
\text { MINING }\end{array}$ & $(+)^{*}$ & $\begin{array}{c}(+)^{*} \\
*\end{array}$ & $(+)^{*}$ & $(+)^{* *}$ & $\begin{array}{c}(+)^{*} \\
*\end{array}$ & $(+) * *$ & $(+)^{* *}$ \\
\hline WIND & & & & & & & \\
\hline OIL \& GAS & & $(+)^{*}$ & & & & & \\
\hline $\begin{array}{l}\text { Correctly } \\
\text { Specified }\end{array}$ & $\mathrm{N}$ & $\mathrm{Y}$ & $\mathrm{N}$ & $\mathrm{Y}$ & $\mathrm{N}$ & $\mathrm{N}$ & Y \\
\hline $\begin{array}{l}\text { HETEROSK- } \\
\text { EDASTIC }\end{array}$ & $\mathrm{Y}$ & $\mathrm{Y}$ & $\mathrm{Y}$ & $\begin{array}{c}\mathrm{N} \\
\text { HOMOSCED- } \\
\text { ASTIC }\end{array}$ & $\mathrm{Y}$ & $\begin{array}{c}\mathrm{N} \\
\text { HOMOSCED } \\
\text {-ASTIC } \\
\end{array}$ & $\mathrm{Y}$ \\
\hline Adj $R^{2}$ & $51 \%$ & $51 \%$ & $42 \%$ & $29 \%$ & $51 \%$ & $47 \%$ & $40 \%$ \\
\hline
\end{tabular}

Values in parentheses denote Standard errors. Statistical significances denoted as: $10 \%(*), 5 \%(* *)$, and $1 \%(* * *)$.

Various independent variables were utilized from one model to another, see (Table 7.1).

These variations stem from economic theory and the physical and social aspects of the parcels of agricultural land involved.

After running the models, tests statistics and econometric diagnosis (above) were conducted, five common outliers (found in all seven models) were omitted because the means of the number of acres sold and the price are 72 acres with standard deviation of 50 acres and $\$ 178,000$ with standard deviation of $\$ 132,000$ respectively, whereas, most of the outliers deviate from that by having few acres and almost a triple of the mean of price. In addition, two variables (elevation and distance to town under 5,000 people) were dropped from consideration due to high correlation coefficients that they have with some variables included in the model. The correlation coefficient of the variables elevation and wind farms is -0.78 and the correlation coefficient of towns under 5,000 people and Distance to K12 is 0.74. Also, Percent Forest was 
dropped because it was only significant in model \#1, which was mis-specified, in one case, and hetroskedastic.

See Table 7.1 (summary of the seven models and energy variables) was produced after the necessary adjustments were made.

\subsection{Results and Analysis}

Total Sale Price (Model \#1, using mineral rights variable and the sixteen counties' dummy variables-Appendix 4) is regressed on all independent variables, including the sixteen counties dummy variables. The F-test indicates that the overall estimated coefficients are statistically different from zero (prob> $\mathrm{F}=0.000$ ). None of the county dummy variables, which were included in this model \#1 only, had statistically significant coefficients. These variables indicate no across county differences in total agricultural land sale prices. On the other hand, Appraised Building Value Building Value, distance from active mining site, Distance to Streams, and the three of land type uses (crop, pasture, and forest) are statistically different from zero at 1\%, 10\%, 10\%, 5\%, 1\%, and $1 \%$ respectively. In addition, the model explains $57 \%$ of the variation in total sale price of agricultural land in north-central West Virginia. However, model \#1 was not correctly specified and heteroskedastic.

Total Sale Price (Model \#2, using mineral rights acres interaction term variable and excluding the counties' dummy variables variable and the sixteen counties dummies-Appendix Appendix 5) is regressed on all independent variables, excluding the sixteen counties dummy variables and instead of acreages of land type uses, variables reflected percent crop and pasture lands within each sale. The F-test indicates that the overall estimated coefficients are statistically different from zero (prob $>\mathrm{F}=0.000$ ). The model explains $54 \%$ of the variations of total sale price of agricultural land in north-central West Virginia. It was correctly specified. However, this model 
is heteroskedastic, therefore, robust standard errors are reported. Appraised, Acres, distance to Interstate, distance to active mining site, distance to oil and gas wells, and distance to streams variables all were significant at $1 \%, 1 \%, 5 \%, 5 \%, 10 \%$, and $5 \%$ respectively.

Ln Total Sale Price (Model \#3, when all independent variables as level variables with mineral rights and acres as interaction term - Appendix 6) is regressed on all independent variables, excluding the sixteen counties dummy variables and instead of land type uses, percent crop and percent pasture were used. In addition, instead of mineral rights as a variable, mineral rights times the number of acres was used. The F-test indicates that the overall estimated coefficients are statistically different from zero (prob> $F=0.000$ ). The model explains $45 \%$ of the variations of total sale price of agricultural land in north-central West Virginia. Mineral Rights Acres, Distance to town between 10,000 and 25,000 people, Distance to town with greater than 25,000 people, Distance to Interstate, Distance to Active mining site, Distance to streams, Acres, and Appraised Building Value Build value all are statistically different from zero at 10\%, $10 \%, 10 \%, 5 \%, 10 \%, 5 \%, 1 \%$, and $1 \%$ respectively. However, the model is mis-specified and heteroskedastic.

Ln Total Price (Model \#4, when appraised building value and acres are logged and others are level variables- Appendix 7) is regressed on all independent variables, excluding the sixteen counties dummy variables and instead of land type uses, percent crop and percent pasture were used. In addition, instead of mineral rights, acres, Appraised Building Value variables, mineral rights times the number of acres, log acres, and log Appraised Building Value respectively were used. The F-test indicates that the overall estimated coefficients are statistically different from zero (prob> $F=0.000$ ). The model explains $33 \%$ of the variations of Price per Acre of agricultural land in north-central West Virginia. It is correctly specified and Homoscedastic. It 
addition, Log Appraised, Mineral Rights Acres, Log Acres, Distance to town with the population between 10,000 and 25,000 people, Active mining site, and Distance to Streams are statistically different from zero at $1 \%, 10 \%, 1 \%, 5 \%, 5 \%$, and $1 \%$ respectively.

Price per Acre (Model \#5, all independent variables are level variables- Appendix 8) is regressed on all independent variables, excluding the sixteen counties dummy variables and instead of land type uses, percent crop and percent pasture were used. In addition, instead of mineral rights, acres, Appraised Building Value variables, mineral rights times the number of acres, $\log$ acres, and log Appraised Building Value respectively were used. The F-test indicates that the overall estimated coefficients are statistically different from zero (prob $>F=0.000$ ). The model explains 54\% of the variations of Price per Acre of agricultural land in north-central West Virginia. Slope, Distance to town between 10,000 and 25,000 people, Active mining site, Distance to streams, Acres, and Appraised Building Value are statistically different from zero at 10\%, 5\%, $5 \%, 5 \%, 1 \%$, and $1 \%$ respectively. However, the model is misspecified and heteroskedastic.

Ln Price per Acre (Model \#6, all independent variables are level variables but used appraised per acre for the building value - Appendix 9) is regressed on all independent variables, excluding the sixteen counties dummy variables and instead of land type uses, percent crop and percent pasture were used. In addition, instead of Appraised Building Value variable, we have Appraised Building Value per acre. The F-test indicates that the overall estimated coefficients are statistically different from zero (prob> $\mathrm{F}=0.000$ ). The model explains $49 \%$ of the variations of Price per Acre of agricultural land in north-central West Virginia. Distance to town between 10,000 and 25,000 people, Active mining site, Distance to streams, Acres, Mineral Rights, and Appraised Building Value per Acre are statistically different from zero at 5\%,10\%, 5\%, 1\%, 10\%, and $1 \%$ respectively. However, the model is Homoscedastic but misspecified. 
Ln Price per Acre (Model \#7, all independent variables are level variables but used log appraised per acre for the building value-Table 7.4) is regressed on all independent variables, excluding the sixteen counties dummy variables and instead of acreage of land types, the variables percent crop and percent pasture were used. In addition, instead of Appraised Building Value and Acres variables, we have log Appraised per Acre and log Acres variables respectively. The F-test indicates that the overall estimated coefficients are statistically different from zero (prob> $\mathrm{F}=$ 0.000). The model explains $43 \%$ of the variations of Price per Acre of agricultural land in northcentral West Virginia. Log Acres, Distance to town between 10,000 and 25,000 people, Active mining site, Distance to streams, Mineral Rights Acres, and log Appraised Building Value per Acre are statistically different from zero at $1 \%, 1 \%, 5 \%, 1 \%, 10 \%$, and $1 \%$ respectively. In addition, the model is correctly specified but heteroskedastic; therefore, the robust standard error was run to fix the problem.

The choice of Ln Price per Acre (model \# 7-Table 7.4) was done on the basis following: the two energy variables (MR and Active mining) are significant in at least four out the seven models. Five of the seven models, M1, M2, M3, M5, and M6, were eliminated from the possibility of being selected either because they are not correctly specified or mineral rights are not significant (See Appendix 10- The Six models side by side-excluding M1 because the counties' dummy variables are not statistically significant).

Only two models were correctly specified (M4 and M7. They explain 33\% and 43\% respectively. According to Adj $\mathrm{R}^{2}$, Akaike information Criterion (AIC), and Schwarz Information Criterion (SIC), Model \#7 is the best fit for our data because the difference in the values of AIC and SIC for the two models is small and the Adj $\mathrm{R}^{2}$ is higher for model number seven. Therefore, it is the model used in our study (our final model). Table 7.3 displays the results of Adjusted $\mathrm{R}^{2}$, 
AIC, and SIC for models four and seven. In addition, the regression output (Table \# 7.4) shows the variables used and the results of Model \#7.

Table 7.2 The Adjusted $\mathbf{R}^{2}$, AIC, and SIC Results

\begin{tabular}{|c|c|c|c|}
\hline Model & Adjusted R & AIC & SIC \\
\hline 4 & 0.29 & 636.922 & 700.499 \\
\hline 7 & 0.4 & 637.658 & 701.235 \\
\hline
\end{tabular}

(See Appendix 12, for a detailed study of Model \#7). 
Table 7.3. Model \#7- Ln Price per Acre

\begin{tabular}{|c|c|}
\hline Dependent variable: Ln Price per Acre & $\begin{array}{l}\text { Estimated Coefficients } \\
\text { (Standard Error) }\end{array}$ \\
\hline Percent of Crop & $\begin{array}{l}-0.002 \\
(0.002)\end{array}$ \\
\hline Percent of Pasture & $\begin{array}{l}-0.000 \\
(0.002)\end{array}$ \\
\hline Ln Appraised Building Value Per Acre & $\begin{array}{c}0.080 \\
(0.009)^{* * * *}\end{array}$ \\
\hline Mineral Rights & $\begin{array}{c}0.165 \\
(0.090)^{*}\end{array}$ \\
\hline Ln Acres & $\begin{array}{c}-0.519 \\
(0.069)^{* * *}\end{array}$ \\
\hline Slope & $\begin{array}{l}-0.007 \\
(0.007)\end{array}$ \\
\hline Distance to town between $5 \& 10 \mathrm{k}$ & $\begin{array}{c}0.003 \\
(0.006)\end{array}$ \\
\hline Distance to town between $10 \& 25 k$ & $\begin{array}{c}-0.018 \\
(0.006) * * *\end{array}$ \\
\hline Distance to town of $25 \mathrm{k} \&$ greater & $\begin{array}{c}0.004 \\
(0.005) \\
\end{array}$ \\
\hline Distance to K 12 & $\begin{array}{l}-0.022 \\
(0.022) \\
\end{array}$ \\
\hline Distance to Interstate & $\begin{array}{l}-0.009 \\
(0.008) \\
\end{array}$ \\
\hline Distance to US route & $\begin{array}{l}-0.009 \\
(0.012) \\
\end{array}$ \\
\hline Distance to Active Mine & $\begin{array}{c}0.022 \\
(0.010)^{* * *}\end{array}$ \\
\hline Distance to Wind Turbine & $\begin{array}{l}-0.002 \\
(0.003)\end{array}$ \\
\hline Distance to Oil \& Gas wells & $\begin{array}{c}0.032 \\
(0.041) \\
\end{array}$ \\
\hline Distance to Streams & $\begin{array}{c}1.325 \\
(0.456)^{* * *}\end{array}$ \\
\hline Constant & $\begin{array}{c}9.762 \\
(0.330)^{* * *}\end{array}$ \\
\hline F-statistic & 14.38 \\
\hline Adj $R^{2}$ & 0.40 \\
\hline $\mathbf{N}$ & 311 \\
\hline
\end{tabular}

Values in parentheses denote Standard errors. Statistical significances denoted as: $10 \%(*), 5 \%(* *)$, and $1 \%(* * *)$. 
As mentioned above the F-test indicates that the overall estimated coefficients are statistically different from zero (prob> $F=0.000$ ) meaning that the F-test for the model suggests that the fitted model is robust and therefore we reject the null hypothesis that all the regression coefficients are collectively zero. Moreover, from our data of 311 observations, the model explains $40 \%$ in the variations of total sale price of agricultural land in north-central West Virginia.

For the energy variables, mineral rights transferred with agricultural land property have a positive coefficient in the model (as was expected). The more acres of mineral rights a parcel transfer contains, the higher its price should be compared to the one that has similar characteristics but less minerals. Moreover, Mineral Rights variable is statistically different from zero (at 10\%). Thus, throughout the 16 counties of North-central West Virginia, when mineral rights are included in the sale, they do contribute to higher agricultural land values. From the coefficient estimate, a $1 / 10$ increase in mineral rights increases the value of the agricultural land by $1.65 \%$ keeping other variables constant. When average dataset values are used for all other variables, per acre price increases by $19 \%$ when $100 \%$ of the acreage of a parcel includes mineral rights compared to no mineral rights transferred with a parcel sale.

Distance to Active mining site contributes positively to total sale price (it has the expected sign). The further a parcel is from active mining site (mining area), the more value it should have compared to the one that has similar characteristics but in a closer distance to active mining site. It is significant at 5\%. Thus, throughout the 16 counties of North-central West Virginia, the further the parcel of agricultural land is located from an active mining site the higher the agricultural land value. If the distance of a parcel of agricultural land from active mining site increases by one mile, the value of the parcel increases by $2.20 \%$ keeping other variables constant. When average dataset 
values are used for all other variables, per acre price increases by $43 \%$ when active mining is moved to the maximum distance in the dataset (24.18 miles).

Distance to oil and gas wells and distance to wind farms variables have positive and negative coefficients, respectively. While the positive sign is expected and the negative sign is not, neither coefficient is statistically different from zero. Thus, throughout the 16 counties of North-central West Virginia, distance to oil and gas wells and wind farms do not influence agricultural land prices. For the oil and gas wells (not significant variable), it could be due to the influence of Natural Gas Horizontal Well Control Act ((HB401) that was passed in 2011, which has provisions that are considered as stringent on the energy producing companies. Examples include oil and gas companies must plug all wells in accordance with rules set by the West Virginia Department of Environment Protection (DEP). Companies must dispose of cuttings and all associated drilling mud in an approved solid waste facility or managed on-site in a way approved by the secretary of DEP and with the consent of the surface owner and grade, terrace and plant, seed or sod the area damaged that is not required in production of the horizontal well. Another example is setback distances from the center of the well pad, 625 feet and 1,500 feet for occupied homes and large poultry or cattle $(2,500 \mathrm{sq}$. ft. or larger) respectively.

These factors could be the ones that helped with reducing externalities and could be a possible explanation to why oil \& gas externalities are not significant in impacting the values of agricultural lands north-central West Virginia.

For the non-energy variables, the coefficient for log appraised building value and log acres variables have their expected signs, positive and negative respectively. Each coefficient is significant at the $1 \%$ level. In addition, their coefficients represent elasticities, meaning that a $1 \%$ 
increase in appraised building value causes the price per acre to increase by $0.08 \%$ and if total acres increases by $1 \%$, the price per acre decreases by $0.51 \%$, holding other variables constant.

Distance to town with population between 10,000 and 25,000 has a negative sign and it is significant at $5 \%$. This is to say that the further a parcel of agricultural land is located from a city with a population between 10,000 and 25,000 the less attractive it is to buyers. It has the expected sign. This result corresponds to what (Shi, Phipps, and Colyer, 1997) found when they used a gravity model to estimate agricultural land values in West Virginia. They concluded that the agricultural land values decrease as farmland move further away from urban areas.

Distance to stream has a positive coefficient (the expected sign) and it is significant at $1 \%$. The further a parcel is from a stream, the more valuable it is compared to one with similar characteristics but in a closer distance to a stream. Probably, a parcel closer to a stream is highly likely to face flooding issues, which means that parcels that are located on areas of higher risks of flooding are less conducive to agricultural activities. Therefore, streams may cause a negative impact on agricultural land prices. If distance of a parcel from a stream increases by 1/10 of a mile, its price increases by $13.25 \%$ holding all other variables constant.

Percent crops and percent pasture have negative coefficients (not the expected sign) and they are statistically insignificant. This result means that throughout the 16 counties of northcentral West Virginia, the type of agricultural land (crops or pasture) does not explain variation in agricultural land prices.

\subsection{Aggregate Impact of Energy Development on Property Values}

To compute the aggregate impact of energy development, we apply the estimated coefficients results from the property value model \#7 to all affected parcels of farmland in Brooke County. Figure 5 shows the location of 176 farmland parcels along with energy development sites 
relative to Brooke County (many of which are located in surrounding states of Ohio and Pennsylvania). The externality impact due to active mining (the only energy development variable with a statistically significant coefficient) is estimated based upon a parcel distance from the closest mining site subtracted from the reduced externality impact located at five miles (double the county average distance to a mining site).

Using Model \#7 coefficient results, farmland values in Brooke County would increase if the closest active mine site was five miles from each parcel. On average, the per acre price is increased by $5 \%$ when reducing the externality impact from active coal mining by moving the closest active mine site to five miles away relative to the current locations of mining operations. The total farmland value lost for the entire county was computed to $\$ 2.4$ million over the 176 parcels, an average of about $\$ 13,900$ per parcel. It means that if someone owns a parcel of farmland in Brooke County, his or her parcel value has on average an estimated loss of its real value measured in the thousands of dollars when the parcel is close to an active coal mining site.

While this study focused only on Brooke County, it is possible to see similar losses for property owners located near mining sites throughout the sixteen counties of north-central West Virginia. This analysis indicates property value losses from proximity to mining sites; however, these losses could be converted to property value gains if there was no mining sites or after these mining sites have been completed and remediated. There is a positive willingness to pay, as indicated by loss of property values, to be located away from active mining sites. 


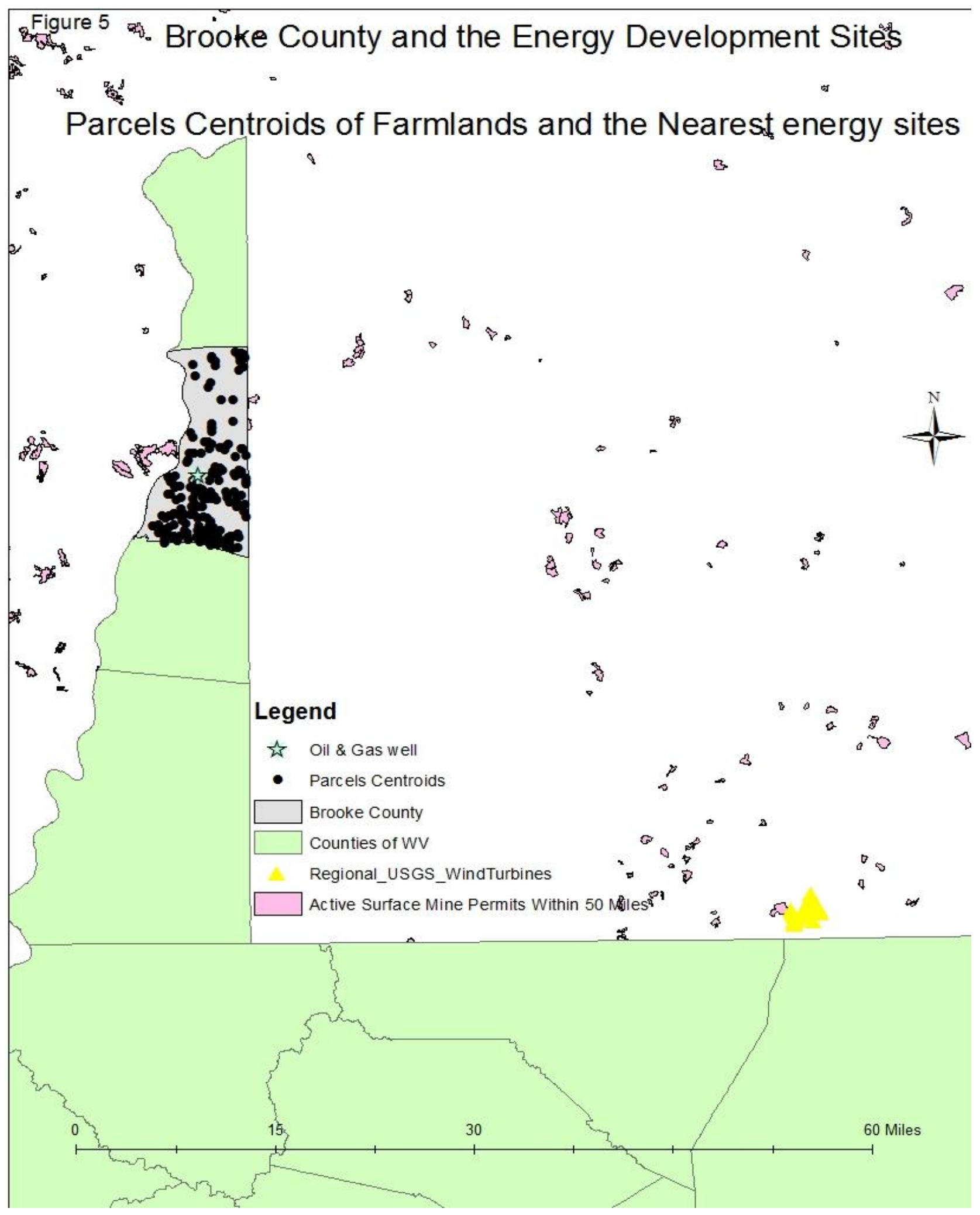

Figure 5. Brooke County and the Energy Development Sites. 


\subsection{CONCLUSION AND POLICY RECOMMENDATIONS}

8.1 Summary

This research performs a thorough study of the available literature on energy development and its impacts on agricultural lands. A hedonic property model is estimated to demonstrate the impact of energy development in the form of coal mining, mineral rights, oil and gas wells sites, and wind turbines on agricultural lands values in 16 counties of north-central West Virginia. Along with energy development variables, this hedonic model includes variables reflecting parcel land use types, slope, and size; building value; and distances to roads, schools, towns, and streams.

Two energy development variables have significant impacts on agricultural land values: active coal mines and mineral rights. The active coal mining variable has a negative, statistically significant impact on agricultural land values in north-central West Virginia. Coal mines decrease agricultural land prices by $2.18 \%$ if the distance between an active mining site and the parcel's centroid decreases by 1 mile, holding all other variables constant. This reduction of the agricultural land values due to proximity to mining sites represents a source of externality on agricultural land values as active coal mining is a source of disamenity to agricultural land owners.

On the other hand, when the mineral rights are included in the property sales, the land value increases. The higher the proportion of mineral rights are there in agricultural lands, the more the agricultural lands are worth. The mineral rights variable coefficient is statistically different from zero (at $10 \%$ ). Thus, throughout the 16 counties of north-central West Virginia, when mineral rights are included in the sale, they do contribute to higher agricultural land values. From the coefficient estimate, a 1/10 increase in mineral rights (amount of mineral rights transferred) increases the value of the agricultural land by $1.65 \%$ keeping other variables constant. 
However, leasing of mineral rights leads to energy companies extracting the minerals. In the case of coal, extracting companies disturb the nearby agricultural lands in order to gain access to their minerals, creating externalities on other people lands. Also, the extraction sites are considered (at least from the environmental aspect) to be high sources of disamenities. Therefore, mineral rights influence agricultural land values, positively (when minerals are not severed) for some land owners and negatively (when minerals are severed) for others.

Distance to oil and gas wells and distance to wind farms variables have positive and negative coefficients, respectively. Neither coefficient is statistically different from zero. Thus, throughout the 16 counties of North-central West Virginia, distance to oil and gas wells and wind farms do not influence agricultural land prices. For the oil \& gas well variable, the provisions of the Natural Gas Horizontal Well Control Act (HB401) passed in 2011 may serve as a mitigating factor in limiting the impact of oil \& gas well externalities on farmland in this part of West Virginia. For the wind turbines, this region of the state does not have many wind farms as a source of energy.

For the non-energy variables, the coefficients for log appraised building value and log acres variables have their expected signs, positive and negative, respectively. Each coefficient is statistically significant at the $1 \%$ level. In addition, their coefficients represent elasticities, meaning that a $1 \%$ increase in appraised building value causes the per acre price to increase by $0.08 \%$; having a building (structure) on a farmland increases its value. Also, for the number of acres, if total acres increases by $1 \%$, the per acre price decreases by $0.6 \%$, holding other variables constant, which means fewer buyers tend to compete for larger parcels versus bigger number that compete for smaller sizes of parcels. 
Distance to town with population between 10,000 and 25,000 has a negative sign and it is statistically significant at a 5\% level. This result means that as a parcel of agricultural land is located farther from a city with a population between 10,000 and 25,000 , its price per acre decreases by $1.8 \%$ as distance increases by one mile, holding other variables constant. This result is similar to what (Shi, Phipps, and Colyer, 1997) found when they used a gravity model to estimate agricultural land values in West Virginia. They concluded that the agricultural land values decrease as farmland move further away from urban areas.

Distance to stream has a positive coefficient (the expected sign) and it is significant at $1 \%$ so that the further a parcel is from a stream, the more valuable it is compared to one with similar characteristics but in a closer distance to a stream. Our explanation for this result is that parcels located closer streams are highly likely to face flooding issues. These parcels are located in areas of higher risks of flooding and are thus less conducive to agricultural and development activities. Therefore, streams have negative impacts on agricultural land prices. If a distance of a parcel from a stream increases by $1 / 10$ of a mile its price increases by $13.2 \%$ holding other variables constant. It is important to note that the average parcel distance to a stream in the dataset is 0.13 miles and the maximum distance is 0.59 miles. Since all parcels are close to streams, this variable has a high coefficient estimate.

Getting GIS data to estimate the aggregate impacts from energy development in all sixteen counties was not possible. Most counties in West Virginia do not have the GIS data available or were unwilling to share it. However, data were available in one county, Brooke County. However, the data available contains fewer parcels (176) of farmland compared to most of the other 16 counties. For example, Preston County has about 1,100 parcels of farmland. With GIS data 
available for the entire county, we could obtain property value estimates to calculate the impacts of energy development on parcels of farmland in the county.

For the aggregate impact of the energy development on agricultural lands in Brooke County, we estimate a property value loss of $\$ 2.4$ million for the owners of 176 parcels of farmland located from current active coal mines compared to being five miles from the nearest active mining site. This estimate means that when someone owns a parcel of farmland in Brooke County, his or her parcel has lost thousands of dollars of sale price value due to active coal mining sites.

While this study focused only on Brooke County, it is possible to see similar losses for property owners located near mining sites throughout the sixteen counties of north-central West Virginia. This analysis indicates property value losses from proximity to mining sites; however, these losses could be converted to property value gains if there was no mining sites or after these mining sites have been completed and remediated. There is a positive willingness to pay, as indicated by loss of property values, to have the mining site be move away from their locations.

\subsection{Comparing our study results to other studies}

Comparing our study to other studies that have examined factors that influence agricultural land values, our model included different independent variables in addition to some independent varibels which have been used in other studies' models. For example, the study conducted by (Huang, et al) on factors influencing Illinois farmland values. In their study, they found similar results when it comes to the decline of farmland value as the parcel size increases as well as the distance to large cities. Another study conducted by (Goodwin and Ortalo-Magné), which focused mainly on agricultural policies, found that agricultural land values are influenced by the support through agricultural policies, like subsidies. 
In addition, the study conducted by (Baen, 1996) found oil and gas activities cause damage to surface land, therefore, the surface land loses its property value. Also, (Weber and Hitaj, 2015) mentioned in the conclusion of his study the two mechanisms of mineral rights when he concluded that drilling can create ecological disamenities and influence the land's suitability for the utilizations that give it value and that Shale gas development influences self-reported agricultural real estate values. Some farmers incorporate their oil and gas rights in the market estimation of their property. Furthermore, increase of the value of the land happens amid the leasing period, not when most drilling happens. Moreover, as to urban impacts, (Shi, Phipps, and Colyer, 1997) found that land values in every county in West Virginia have experienced numerous urban impacts because of being surrounded by various vast metropolitan areas. However, one major difference is that our study included some energy development variables to show their influence on agricultural land values in West Virginia.

\subsection{Limitations and Policy Recommendations}

The model only explains $40 \%$ of the variations of per acre price of agricultural land in north-central West Virginia. Probably, if we had data in a period longer than three years, the model could have produced different results. In producing aggregate impact results, the lack of access to a detailed GIS information at the county level for counties with larger numbers of farmland parcels, like Preston County, would produce estimates of farmland value impacts in more agricultural important areas of north-central West Virginia. Getting GIS data to do the aggregate impacts on all sixteen counties was not possible (most counties don't have the GIS data available or they don't want to share it). However, it was possible for one county (Brooke County) that has the data available but with fewer parcels (176) of farmland compared to most counties, for example, Preston County that has about 1,100 parcels of farmland. 
Related to policy recommendations, agricultural land values in north-central West Virginia are influenced by inclusion of mineral rights and externalities creates by energy development, specifically coal mining. Since mineral rights have a positive influence on land values, one policy recommendation is related to conservation easement values for farmland in West Virginia. If conservation easement values are generated from agricultural land sale prices, then knowledge about whether mineral rights are included in a sale or not is important information to gather in order to ensure that easement values are not set too high. Unfortunately in most West Virginia counties, information about inclusion of mineral rights in sales is often kept separate from transfer information of surface rights. This makes acquiring mineral right transfer for each agricultural land data time consuming and costly, possibly leading to over-valuation of conservation easement values.

Another recommendation related to the negative influence of active coal mining sites on agricultural land values is that the issuance of surface coal mining permits by the West Virginia Department of Environment Protection. This process should account for the property value impacts from coal mining on surrounding lands. Based upon our results from the north-central part of the state, current laws regulating mining and reclamation of coal mines do not adequately prevent negative external impacts from occurring on surrounding agricultural lands. 


\section{REFERENCES}

Abbasi, S.A., and N. Abbasi. 2000. "The likely Adverse Environmental Impacts of Renewable Energy Sources.” Applied Energy 65:121-144.

Akella, A.K., R.P. Saini, and M.P. Sharma. 2009. "Social, Economical and Environmental Impacts of Renewable Energy Systems" Journal of Renewable Energy, ELSEVIER, 34, pp. 390-396

Baen, J.S. 1996. "The Impact of Mineral Rights and Oil and Gas Activities on Agricultural Land Values.” Appraisal Journal 64 (1): 67-75.

Banzhaf, H. S., and P. Jawahar. 2005. "Public benefits of Undeveloped Lands on Urban Outskirts: Non-market Valuation Studies and Their Role in Land Use Plans." Washington, DC: Resources for the Future. June 2005. 47 pp.

Bennett, A., J. Loomis. 2015. “Are Housing Prices Pulled Down or Pushed Up by Fracked Oil and Gas Wells? A Hedonic Price Analysis of Housing Values in Weld County, Colorado." Society \& Natural Resources 28 (11): 1168-1186.

Blaacker, D., J. Woods, and C. Oliver. 2012. "How Big is Big Coal? Public Perceptions of the Coal Industry's Economic Impact in West Virginia." Organization and Environment 25 (4): 385-401.

Black, K. J., S. McCoy, and J.G. Weber. 2016. "When Externalities are Taxed: The Effects and Incidence of Pennsylvania's Impact Fee on Shale Gas Wells.” Working Paper, USAEE Working Paper No. 16-272. Available at SSRN: https://ssrn.com/abstract=2829409

Borchers, A., J. Ifft, and T. Kuethe. 2014. "Linking the Price of Agricultural Land to Use Values and Amenities." American Journal of Agricultural Economics 96 (5):1307-1320.

Chicoine, D.L. 1981. "Farmland Values at the Urban Fringe: An Analysis of Sale Prices." Land Economics, 57(3):353-362.

Collins, A.R., and K. Nkansah. 2015. "Divided Rights, Expanded Conflict: Split Estate Impacts on Surface Owner Perceptions of Shale Gas Drilling." Land Economics 91 (4): 688-703.

Considine, T. 2010. "The Economic Impacts of the Marcellus Shale: Implications for New York, Pennsylvania, and West Virginia." Report to The American Petroleum Institute, published by Natural Resource Economics, Inc. Laramie, Wyoming.

Considine, T., R. Watson, R., R. Entler, and J. Sparks. 2009. "An Emerging Giant: Prospects and Economic Impacts for Developing Marcellus Shale.” Dep. Energy and Mineral Engineering, Penn State University.

Cornes, R., and T. Sandler. 1986 "The Theory of Externalities, Public Goods, and Club Goods." Cambridge: Cambridge Univ. Press.

Devine-Wright, P., 2005. "Beyond NIMBYism: Towards an Integrated Framework for Understanding Public Perceptions of Wind Energy." Wind Energy 8, pp. 125-139.

Dincer, I. 1999. “Environmental Impacts of Energy.” Energy Policy 27 (14), 845-854. 
Elad, R. L., I. D. Clifton, and J. E. Epperson. 1994. "Hedonic Estimation Applied to the Farmland Market in Georgia." Journal of Agricultural and Applied Economics 26 (2): 351- 66.

ESRI 2011. ArcGIS Desktop: Release 10. Redlands, CA: Environmental Systems Research Institute.

Fershee, J.P., 2012. Oil and Gas Evolution: Learning From the Hydraulic Fracturing Experiences in North Dakota and West Virginia. The. Tex. Wesleyan L. Rev. 19, p. 23.

Fitzgerald, T. 2015. "Importance of Mineral Rights and Royalty Interests for Rural Residents and Landowners" Choices 29(4):1-7.

Freeman, A.M. 2003. The Measurement of Environment and Resource Values: Theory and Methods. 2nd. ed. Washington, D.C.: Resources for the Future.

Goodwin, B.K., and F. Ortalo-Magné. 1992. "The Capitalization of Wheat Subsidies into Agricultural Land Values." Canadian Journal of Agricultural Economics 40 (1): 37-54.

Hausman, C., and R. Kellogg. 2015. 'Welfare and Distributional Implications of Shale Gas' Brookings Papers on Economic Activity.

Higginbotham, A., A. Pellillo, T. Gurley-Calvez, and T.S. Witt. 2010. The Economic Impact of the Natural Gas Industry and the Marcellus Shale Development in West Virginia in 2009. Bureau of Business and Economic Research, College of Business and Economics, West Virginia University.

Huang, H.X., G. Miller., B. J. Sherrick., and M. I. Gomez. 2006. "Factors influencing Illinois farmland values" American Journal of Agriculture Economics 88 (2): 458-470.

Kay, D.R., W.M., Edwards, P.A., Duffy. 2016. Farm management. 8th.. ed. New York, NY McGraw-Hill Education.

Komarek, T. 2015. Labor Market Dynamics and the Unconventional Natural Gas Boom: Evidence from the Marcellus Region. Working Paper. Retrieved from:

http://www.researchgate.net/publication/275354176_Labor_Market_Dynamics_a nd_Th e_Unconventional_Natural_Gas_Boom_Evidence_from_the_Marcellus_Region

Kunz, T. H., E. B. Arnett, W. P. Erickson, A. R. Hoar, G. D. Johnson, R. P. Larkin, M. D. Strickland, R. W. Thresher, and M. D. Tuttle. 2007. "Ecological Impacts of Wind Energy Development on Bats: Questions, Research Needs, and Hypotheses." Frontiers in Ecology and the Environment 5:315- 324.

Kuvlesky, W.P., L.A. Brennan, M.L. Morrison, K.K. Boydston, B.M. Ballard, and F.C. Bryant. 2007. "Wind Energy Development and Wildlife Conservation: Challenges and Opportunities." J. Wildl. Manage. 71, pp. 2487-2498.

Libecap, G.D. 1986. "Property Rights in Economic History: Implications for Re- search." Explorations in Economic History 23 (July): 227-252.

Lipscomb, C., Y. Wang, and S. Kilpatrick. 2012. "Unconventional Gas Development and Real Estate Valuation Issues.” The Review of Regional Studies 42, pp. 161-175.

Lund, P.D. 2009. "Effects of Energy Policies on Industry Expansion in Renewable Energy." Renewable Energy 34, pp. 53-64. 
Morris, A.C. 2016. "Build A Better Future for Coal Workers and Their Communities." Brookings: Climate and Energy Economics Discussion Paper.

Palmquist, R. B., and L.E. Danielson. 1989. "A hedonic study of the effects of erosion control and drainage on farmland values." American Journal of Agricultural Economics 71 (1): $55-62$.

Paredes, D., T. Komarek, and S. Loveridge. 2015. "Income and Employment Effects of Shale Gas Extraction Windfalls: Evidence from the Marcellus Region." Energy Economics 47: $112-120$.

Plantinga, A.J., R.N. Lubowski, and R.N. Stavins. 2002. "The Effects of Potential Land Development on Agricultural Land Prices." Journal of Urban Economics 52(2):561-8

Powers, W.L. 1980. "Mines and Minerals-Mineral Reservation-Surface Ownership Includes at Surface Substances and Those Near Surface Substances Whose Removal Involves Destruction of Surface by Any Reasonable Method Known at Time Extraction Is Planned." St. Mary's Law Journal 12: 580. Print.

Rosen, S. 1974. "Hedonic Prices and Implicit Markets: Product Differentiation in Pure Competition." Journal of Political Economy 82 (January/February): 34-55

Roy, A.A., P.J.Adams, and A.L. Robinson. 2013. "Air Pollutant Emissions from the Development, Production, and Processing of Marcellus Shale Natural Gas." Journal of the Air and Waste Management Association 64(1):19-37.

Schumacher, E.F. 1977. Shumacher on Energy: Speeches and Writings of E.F. Schumacher. G. Kirk, ed. London: Jonathan Cape.

Shi, Y. J., T. T. Phipps, and D. Colyer. 1997. "Agricultural Land Values under Urbanizing Influences." Land Economics 73 (1): 90- 100.

Soeder, D.J., and W.M.Kappel. 2009. Water Resources and Natural Gas Production from the Marcellus Shale. USGS. Fact Sheet2009-3032.(US Geological Survey, West Trenton, NJ). Available at http://pubs.usgs.gov/fs/2009/3032/pdf/FS2009-3032.pdf.

Stevens, P. 2012. The 'Shale Gas Revolution': Developments and Changes. London, UK: Chatham House

Stevens, P. 2010. The 'Shale Gas Revolution': Hype and Reality, Chatham House Report, September.

Varun, R. Prakash, and I.K. Bhat. 2009. "Energy, Economics and Environmental Impacts of Renewable Energy Systems." Renewable and Sustainable Energy Reviews 13 (9): $2716-2721$.

Weber, J. G., J. Burnett, and I. M. Xiarchos. 2014. Shale Gas Development and Housing Values Over a Decade: Evidence from the Barnett shale, Working Paper.

Weber, J.G., and C. Hitaj. 2015. "What Can We Learn about Shale Gas Development from Land Values? Opportunities, Challenges, and Evidence from Texas and Pennsylvania." Agricultural and Resource Economics Review 44(2): 40-58.

"WEST VIRGINIA CODE." WV Code 16, www.wvlegislature.gov/wvcode/chapterentire.cfm?chap=22\&art=6A§ion=16\#01. 
West Virginia field office. 2016 "2016 Agricultural Statistics." West Virginia Dept. Agriculture. Bull. N0 47, Sep.

West Virginia field office. 2016 "2016 Agricultural Statistics." West Virginia Dept. Agriculture. Bull. N0 47, Sep

West Virginia Office of Miners' Health, Safety and Training. 2015 "2015 Statistical Report and Directory of Mines" West Virginia Dept. Commerce.

West Virginia's Wind Projects (Operating and Permitted). Available: http://www.wvcommerce.org/App_Media/assets/doc/energy/WindMap_WEB.pdf [accessed july17, 2017]

Wooldridge, J. 2003. Introductory Econometrics: A Modern Approach. Mason, OH: Thomson/Southwestern.

WVGES. 2017. "Summary Data and Statistics." West Virginia Geologic and Economic Survey. Available: http://www.wvgs. wvnet.edu/www/datastat/dataclco.htm [accessed July 17, 2017]

Zhang, W., and C.J. Nickerson. 2008. "Housing Market Bust and Farmland Values: Identifying the Changing Influence of Proximity to Urban Centers." 2013 Annual Meeting, August 46, 2013 Washington DC. No. 149870. Agricultural and Applied Economics Association. 


\section{APPENDICIES}

\section{Appendix 1. Detailed Description of Agricultural Land Production in West Virginia}

(From West Virginia Annual Bulletin N0.47.)

\section{Appendix 1.1. Total acres of farms}

\begin{tabular}{|l|c|}
\hline Year & 2015 \\
\hline Number of Farms & 20,900 \\
\hline Total acres & 3.60 million \\
\hline Average acres per farm & 172 \\
\hline
\end{tabular}

In 2015, the state of West Virginia had 20,900 farms that totaled 3.6 million acres. There were 804,006 acres, 1,595,463 acres, 570,000 acres, 50,000 acres, and 27,000 acres of Cropland, Pastureland, Other Hay, Corn for Grain, and Planted Soybeans respectively in 2016. For the northern West Virginia, 242,575 acres, 435,038 acres, 186,800 acres, 5,300 acres, 500 acres of

Cropland, Pastureland, Other Hay, Corn for Grain, and Planted Soybeans respectively of the total farmland acres in 2016. Therefore, the northern West Virginia represented 30\%, 27\%, 33\%, $11 \%$, and $2 \%$ of the total acres of Cropland, Pastureland, Other Hay, Corn for Grain, and Planted Soybeans respectively in 2016.

From the total production, the state produced 969,000 tons of Other Hay, 5,180,000 bushels of Corn for Grain, 1,248,000 bushels of Soybeans, 390,000 heads of All Cattle, 9,000 heads of Milk Cows, and 36,000 heads of Sheep and Lambs. From the total state's production, the northern West Virginia accounted for 286,100 tons of Other Hay, 378,000 bushels of Corn for Grain, 19,600 bushels of Soybeans, 92,900 heads of All Cattle, 2,900 heads of Milk Cows, and 7,700 heads of Sheep and Lambs. Therefore, the northern West Virginia represented 30\%, 7\%, 2\%, $24 \%, 32 \%$, and $21 \%$ of the total production of Other Hay, Corn for Grain, Soybeans, All Cattle, Milk Cows, and Sheep and Lambs respectively in 2016. 


\section{Appendix 1.2. Cropland and Pastureland}

\begin{tabular}{|l|c|c|}
\hline County & $\begin{array}{c}\text { Total Cropland2/ } \\
\text { (Rented \& Non-rented) }\end{array}$ & $\begin{array}{c}\text { Total Permanent Pasture2/ } \\
\text { (Rented \& Non-rented) }\end{array}$ \\
\hline & Acres & Acres \\
\hline Barbour & 19,206 & 40,381 \\
\hline Brooke & 4,344 & 4,735 \\
\hline Doddridge & 9,964 & 29,101 \\
\hline Hancock & 3,064 & 2,227 \\
\hline Harrison & 25,745 & 59,127 \\
\hline Marion & 12,702 & 23,300 \\
\hline Marshall & 22,769 & 31,912 \\
\hline Monongalia & 14,947 & 25,804 \\
\hline Ohio & 11,859 & 10,582 \\
\hline Pleasants & 4,138 & 9,234 \\
\hline Preston & 44,902 & 59,949 \\
\hline Ritchie & 17,571 & 40,421 \\
\hline Taylor & 10,403 & 24,207 \\
\hline Tyler & 11,506 & 21,078 \\
\hline Wetzel & 7,632 & 15,750 \\
\hline Wood & 21,823 & 37,230 \\
\hline Total & $\mathbf{2 4 2 , 5 7 5}$ & $\mathbf{4 3 5 , 0 3 8}$ \\
\hline
\end{tabular}

\begin{tabular}{|l|c|c|}
\hline State & $\begin{array}{c}\text { Total Cropland2/ } \\
\text { (Rented \& Non- } \\
\text { rented) }\end{array}$ & $\begin{array}{c}\text { Total Permanent Pasture2/ } \\
\text { (Rented \& Non-rented) }\end{array}$ \\
\hline Total & $\mathbf{8 0 4 , 0 0 6}$ & $\mathbf{1 , 5 9 5 , 4 6 3}$ \\
\hline
\end{tabular}

$30 \%$ of the total cropland is within the study area.

$27 \%$ of the total pastureland in within the study area. 
Appendix 1.3. Other Hay

\begin{tabular}{|c|c|c|}
\hline & $\begin{array}{c}\text { Harvested } \\
2015\end{array}$ & Production \\
\hline County & Acres & Tons \\
\hline Barbour & 19,200 & 27,000 \\
\hline Brooke & 3,100 & 5,000 \\
\hline Doddridge & 6,300 & 9,900 \\
\hline Hancock & 1,500 & 2,000 \\
\hline Harrison & 18,700 & 28,200 \\
\hline Marion & 12,800 & 19,300 \\
\hline Marshall & 18,400 & 27,000 \\
\hline Monongalia & 13,100 & 18,700 \\
\hline Ohio & 7,900 & 10,900 \\
\hline Pleasants & 3,000 & 4,900 \\
\hline Preston & 26,000 & 44,800 \\
\hline Ritchie & 14,800 & 19,900 \\
\hline Taylor & 9,900 & 18,300 \\
\hline Tyler & 7,900 & 12,900 \\
\hline Wetzel & 6,300 & 7,900 \\
\hline Wood & 17,900 & 29,400 \\
\hline NORTHWEST & $\mathbf{1 8 6 , 8 0 0}$ & $\mathbf{2 8 6 , 1 0 0}$ \\
\hline & &
\end{tabular}

\begin{tabular}{|l|c|l|}
\hline STATE & Acres & Tons \\
\hline Total & $\mathbf{5 7 0 , 0 0 0}$ & 969,000 \\
\hline
\end{tabular}

$33 \%$ of the total other hay was harvested from the study area.

$30 \%$ of the total other hay production came from the study area. 
Appendix 1.4. Corn for Grain

\begin{tabular}{|c|c|c|c|c|c|c|}
\hline \multirow{2}{*}{ County } & \multicolumn{6}{|c|}{2015} \\
\hline & $\begin{array}{c}\text { All } \\
\text { Planted }\end{array}$ & \multicolumn{3}{|c|}{ Harvested } & \multirow{2}{*}{$\begin{array}{c}\text { Yield } \\
\text { per } \\
\text { Acre }\end{array}$} & Production \\
\hline & & & Acre & & & Bushels \\
\hline \multicolumn{2}{|l|}{ Barbour } & - & & - & - & - \\
\hline \multicolumn{2}{|l|}{ Brooke } & - & & - & - & - \\
\hline \multicolumn{2}{|c|}{ Doddridge } & - & & - & - & - \\
\hline \multicolumn{2}{|c|}{ Hancock } & - & & - & - & - \\
\hline \multicolumn{2}{|l|}{ Harrison } & - & & - & - & - \\
\hline \multicolumn{2}{|l|}{ Marion } & - & & - & - & - \\
\hline \multicolumn{2}{|c|}{ Marshall } & - & & - & - & - \\
\hline \multicolumn{2}{|c|}{ Monongalia } & - & & - & - & - \\
\hline \multicolumn{2}{|c|}{ Ohio } & - & & - & - & - \\
\hline \multicolumn{2}{|l|}{ Pleasants } & - & & - & - & - \\
\hline \multicolumn{2}{|l|}{ Ritchie } & - & & - & - & - \\
\hline \multicolumn{2}{|l|}{ Taylor } & - & & - & - & - \\
\hline \multicolumn{2}{|l|}{ Tyler } & - & & - & - & - \\
\hline \multicolumn{2}{|l|}{ Preston } & 2,700 & 1,810 & 117.1 & 212,000 & \\
\hline \multicolumn{2}{|l|}{ Wetzel } & - & & - & - & - \\
\hline \multicolumn{2}{|l|}{ Wood } & 600 & 500 & 153.8 & 76,900 & \\
\hline \multicolumn{2}{|c|}{ Other 1/ } & 2,000 & 790 & 112.8 & 89,100 & \\
\hline \multicolumn{2}{|c|}{ NORTHWEST } & 5,300 & 3,100 & 383.7 & $\mathbf{3 7 8 , 0 0 0}$ & \\
\hline
\end{tabular}

\begin{tabular}{|l|l|l|l|ll|}
\hline State & & $\mathbf{5 0 , 0 0 0}$ & $\mathbf{3 5 , 0 0 0}$ & $\mathbf{1 4 8 . 0}$ & $\mathbf{5 , 1 8 0 , 0 0 0}$ \\
\hline
\end{tabular}

$11 \%$ of Corn for Grain was planted in the study area.

$7 \%$ of Corn for Grain was harvested from the study area. 


\section{Appendix 1.5. Soybeans}

\begin{tabular}{|c|l|l|l|}
\hline County & $\begin{array}{l}\text { Planted } \\
\text { (acres) }\end{array}$ & $\begin{array}{l}\text { Harvested } \\
\text { (acres) }\end{array}$ & $\begin{array}{l}\text { Production } \\
\text { (Bushels) }\end{array}$ \\
\hline Barbour & & & \\
\hline Brooke & & & \\
\hline Doddridge & & & \\
\hline Hancock & & & \\
\hline Harrison & & & \\
\hline Marion & & & \\
\hline Marshall & & & \\
\hline Monongalia & & & \\
\hline Ohio & & & \\
\hline Pleasants & & & \\
\hline Preston & & & \\
\hline Ritchie & & & \\
\hline Taylor & & & \\
\hline Tyler & & & \\
\hline Wetzel & & & \\
\hline Wood & & & 19,600 \\
\hline Other & 500 & 460 & \\
\hline Northwest & 500 & 460 & \\
\hline
\end{tabular}

\begin{tabular}{|l|l|l|l|}
\hline State & 27,000 & 26,000 & $1,248,000$ \\
\hline
\end{tabular}

$2 \%$ of the total acres planted for soybean was produced from the study area.

$2 \%$ of the total production of soybean was produced from the study area. 
Appendix 1.6. All Cattle and milk cows 2016

\begin{tabular}{|l|c|c|}
\hline County & $\begin{array}{c}\text { All } \\
\text { Cattle }\end{array}$ & Milk Cows \\
\hline Barbour & 9,500 & 200 \\
\hline Brooke & 1,900 & 100 \\
\hline Doddridge & 3,200 & - \\
\hline Hancock & 600 & - \\
\hline Harrison & 11,000 & - \\
\hline Marion & 3,600 & - \\
\hline Marshall & 5,700 & 200 \\
\hline Monongalia & 5,600 & - \\
\hline Ohio & 3,700 & 300 \\
\hline Pleasants & 1,300 & - \\
\hline Preston & 21,000 & 900 \\
\hline Ritchie & 8,800 & - \\
\hline Taylor & 5,600 & - \\
\hline Tyler & 3,500 & - \\
\hline Wetzel & 1,100 & - \\
\hline Wood & 6,700 & 100 \\
\hline Other & 100 & 1,100 \\
\hline Total & 92,900 & $\mathbf{2 , 9 0 0}$ \\
\hline
\end{tabular}

\begin{tabular}{|l|l|l|}
\hline State & $\begin{array}{l}\text { All } \\
\text { Cattle }\end{array}$ & Milk Cows \\
\hline Total & 390,000 & 9,000 \\
\hline
\end{tabular}

$24 \%$ of all cattle was produced from the study area.

$32 \%$ of milk cows was produced from the study area. 


\section{Appendix 2. GIS PART}

\section{The following details explain how the GIS data was gathered.}

Oil and gas wells, surface mining, surface water

February 28, 2017

\section{Oil and gas wells}

1. PA: Data source is "Oil and Gas Locations - Conventional Unconventional" dataset obtained from PASDA website. Original source is PA Department of Environmental Protection. Link: http://www.pasda.psu.edu/uci/DataSummary.aspx?dataset=1088

a. Extracted wells from statewide dataset into 10 mile buffer. 10 mile buffer was used because wells are very widespread and 50 mile buffer was not necessary. Based on the WELL_STATU attribute, the following types of well points were removed:
a. Abandoned
b. DEP abandoned list
c. DEP orphan list
d. DEP Plugged
e. Operator reported not drilled
f. Plugged OG well
g. Proposed but never materialized
h. Regulatory inactive status
i. (Pretty much only kept those listed as Active)

b. This left a total of 3923 wells in the 10 mile buffer zone in PA. Also removed the following based on WELL_TYPE, leaving total of 3714 wells in the 10 mile buffer.
a. Dry hole
b. Injection
c. Observation
d. Storage well
e. Undetermined
f. Waste disposal

c. Selected horizontal (unconventional) wells and attributed those separately. N=1247 are unconventional.

2. OH: Data source is Ohio Department of Natural Resources, Division of Oil and Gas. Link: https://gis.ohiodnr.gov/MapViewer/?config=oilgaswells

a. There were a total of 145,120 wells in the 27 counties within 50 miles originally. Based on the MAPSYMBOL attribute, the following types of well point locations were removed/excluded:

- Brine for dust control 
- Dry hole (any)

- Expired permit

- Injection

- Lost hole

- Observation

- Permitted location

- Plugged (any)

- Solution mining

- Stratigraphy test

- Unknown

- Water supply

b. Query used to select wells: "MAPSYMBOL_" = 'Coalbed methane' OR "MAPSYMBOL_" = 'Gas' OR "MAPSYMBOL_" = 'Gas and oil show' OR "MAPSYMBOL_" = 'Gas show' OR "MAPSYMBOL_" = 'Gas with oil show' OR "MAPSYMBOL_" = 'Oil' OR "MAPSYMBOL_" = 'Oil and gas' OR "MAPSYMBOL_" = 'Oil and gas converted to water' OR "MAPSYMBOL_" = 'Oil show' OR "MAPSYMBOL_" = 'Oil with gas show'

c. Were Removed: all wells that had a date for PLUG_DATE (plugged).

d. wells that were horizontal (unconventional or fracked) and flagged those) were selected. Used Well Number and "SLANT" field to determine horizontal wells.

e. Wells used were limited to just those within 10 miles (rather than 50 miles). This left a total of 9051 wells in the study area in Ohio. Of these, there are 8930 conventional oil and gas wells in $\mathrm{OH}$ within 10 miles of the selected counties, and 121 horizontal wells in the same area.

3. WV: Downloaded WV Department of Environmental Protection oil and gas well locations from here: https://tagis.dep.wv.gov/home/Downloads

a. Limited oil and gas wells to 10 mile buffer

b. Removed all wells with following WellUse designation:

i. Brine disposal

ii. Fluid injection

iii. Observation

iv. Solution mining

v. Storage

c. Removed all wells with Permit type $=$ Plugging

d. Removed all wells with WellStatus $=$
a. Plugged
b. Abandoned
c. Never drilled
d. Never issued
e. Permit application
f. Permit issued
g. Abandoned/plugged
h. Future use 
e. This leaves a total of $n=33888$ wells in the 10 mile buffer area in WV. Labeled horizontal wells.

4. Maryland:
a. Initially used data provided on ArcGIS Online map viewer from FrackTracker. Link: https://www.arcgis.com/home/item.html?id=437d27c219604f61a8e2573f20a0b89e

b. Original data from Maryland Department of the Environment. UPDATE: this layer was found to include natural gas STORAGE wells. No good.

c. Found this resource instead: http://mde.maryland.gov/programs/Land/mining/Mapping/Documents/www.mde.state.m d.us/assets/document/mining/NaturalGasWellLocationMap.pdf

d. Entered XY coordinates for natural gas wells in southern Garrett County from above PDF map. Converted to shapefile.

e. Horizontal/vertical well status is unknown for MD wells.

\section{FOR ALL STATES:}

Merged oil and gas wells in to single shapefile of oil and gas wells (presumed active) within 10 miles of the study area. Attributes include NRAC_NTE which indicates if well is horizontal (fracked) or not, and API or permit number.

Final dataset is named Final_OilGasWells_Within10Miles.shp

\section{Surface Coal Mining}

(Active)

1. Pennsylvania

a. Downloaded bituminous mine permits from PASDA (via PA DEP) link: http://www.pasda.psu.edu/uci/DataSummary.aspx?dataset=367

b. Limited above dataset to surface mine permits, in 50 mile buffer surrounding study area counties. All permits are surface (including mining, refuse, reclaiming). Dataset appears to be just recent permits (no out of date info).

2. Ohio

a. No current online downloadable data. Used dataset last updated in 2013, obtained from Ohio DNR. Includes active surface mines at that time.

3. Maryland

a. No current online downloadable data. Used dataset last updated in 2013, includes outlines of active (since 2000) surface mines, obtained from MD DNR.

4. West Virginia

a. Obtained current coal mine permit dataset from WVDEP TAGIS download page.

b. Removed permits for underground mines

c. Removed permits with MSTATUS indicating:

i. Phase 1 or 2 release

ii. Reclaimed

iii. Revoked

iv. Approved inactive

5. All states: 
Combined active surface permit datasets into single dataset. Final dataset is named Final_ActiveSurfaceMinePermits_Within50Miles.shp

\section{Surface water}

1. National Hydrography Dataset high resolution data was downloaded for WV (includes surrounding states drainage). LINK: https://nhd.usgs.gov/data.html

2. Clipped the following datasets to 10 mile buffer (water features are very evenly distributed, buffer distance does not matter, especially along Ohio border)

NHD 1:24000 scale flowlines (streams)

NHD 1:24,000 scale waterbodies (ponds)

NHD 1:24,000 scale areal features (wide rivers, reservoirs)

3. Converted each to raster format with $30 \mathrm{~m}$ cell size

4. Merged above into single "water" feature grid with values of 1,2,3. Values of 1 indicate streams, values of 2 indicate waterbodies, values of 3 indicate areal features (usually wide rivers). Final grid is named / rasters/surfwater 
March 28, 2017

\section{Distance to towns (by town population)}

Used 50 mile buffer

Data source used: ESRI Data \& Maps (2012) US Populated Place Areas dataset, which includes incorporated places and Census designated places from US Census Bureau. Population data are from 2010.

Towns were grouped according to population categories below. There were $n=39$ towns with population $<100$ that were excluded altogether.

\begin{tabular}{|l|l|l|}
\hline Shapefile name & Population (2010) & Number within 50 mi radius \\
\hline AreaTowns_below5k & Population $>100$ and $<=5000$ & 810 \\
\hline AreaTowns_5kto10k & Population $>5000$ and $<=10,000$ & 74 \\
\hline AreaTowns_10to25k & Population $>10,000$ and $<=25,000$ & 45 \\
\hline AreaTowns_25Up & Population $>25,000$ & 16 \\
\hline
\end{tabular}

\section{Distance to roads (by type)}

Used 50 mile buffer

Roads were mapped using ESRI Data \& Maps (2012) “Highways” dataset. From the metadata:”U.S. Highways represents the major and minor highways of the United States. These include interstates, U.S. highways, state highways, major roads, and minor roads. This dataset is from the Census 2000 TIGER/Line files. It contains all Class 1, 2, and 3 road segments plus any other roads segments necessary to provide network connectivity for the Class_Rte field."

Road types include:

Interstates: shapefile saved as Area_Interstates.shp

US Routes: Shapefile saved as Area_USRoutes.shp

State Routes: Shapefile saved as Area_StateRoutes.shp

\section{Distance to schools}

Used 10 mile buffer (schools are pretty widespread and do not need entire 50 mile buffer)

Data sources:

Maryland: Public K12 Schools, Private K12 schools, from Maryland iMAP website:

http://data.imap.maryland.gov/datasets?q=School

West Virginia: Edited K12 schools from WV Department of Education

$\underline{\text { http://wvgis.wvu.edu/data/dataset.php? } \mathrm{ID}=180}$. Colleges, universities and vocational schools from older WVDE dataset.

Ohio, Pennsylvania: schools from GNIS points (USGS), edited using updated school listings from www.publickschoollisting.com website to remove closed or consolidated schools.

FINAL school datasets:

- Area_colleges_VoTech_Within10Miles.shp 
- Area_K12Schools_Within10Miles.shp

\section{Elevation/elevation derived information within parcel buffer:}

Elevation was obtained from the National Elevation Dataset (NED) 30m dataset provided by the US Geological Survey. Average elevation within the parcel buffer was found using the ArcGIS Spatial Analyst extension.

Percent slope was derived from elevation using the ArcGIS Spatial Analyst's Slope function. Average percent slope within the parcel buffer was found using the ArcGIS Spatial Analyst extension. Degree option was used instead. 


\section{Appendix 3. Spatial Autocorrelation Report Per Acre Price (ArcMap 10.4.1)}

It was produced using "Spatial Autocorrelation function" under the Spatial Statistics Tools in ArcMap 10.4.1

Moran's Index: 0.252232

z-score: $0.556284 \square$

p-value: 0.578017

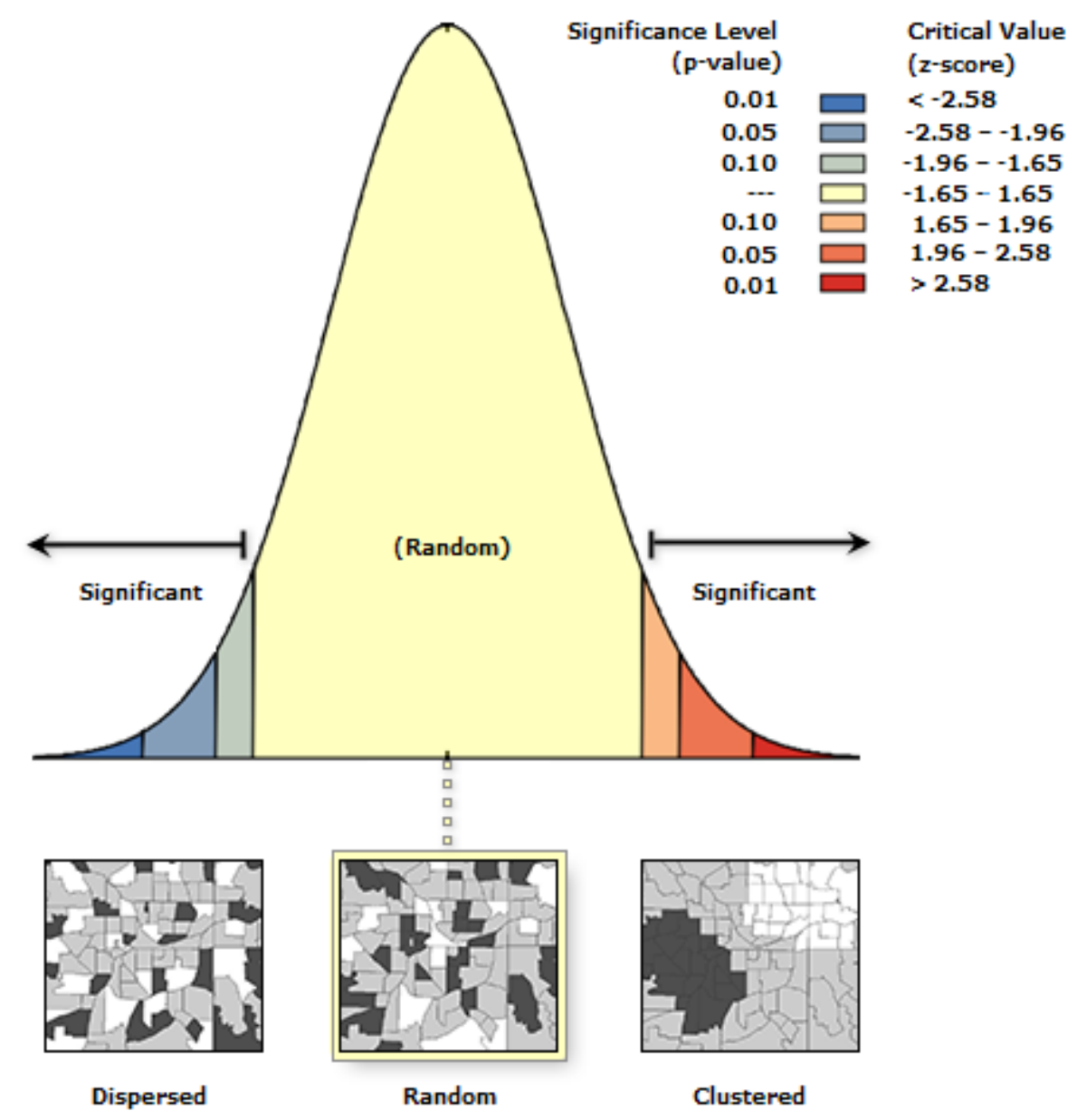

Given the $z$-score of 0.556284146226 , the pattern does not appear to be significantly different than random. 
Appendix 3.1 Global Moran's I Summary

\begin{tabular}{|r|l|}
\hline Moran's Index: & 0.252232 \\
\hline Expected Index: & -0.003268 \\
\hline Variance: & 0.210954 \\
\hline z-score: & 0.556284 \\
\hline p-value: & 0.578017 \\
\hline
\end{tabular}

\section{Appendix 3.2 Dataset Information}

\begin{tabular}{|r|l|}
\hline Input Feature Class: & Points_UTM \\
\hline Input Field: & PRICEPERAC \\
\hline Conceptualization: & INVERSE_DISTANCE \\
\hline Distance Method: & EUCLIDEAN \\
\hline Row Standardization: & False \\
\hline Distance Threshold: & 794080.4595 Meters \\
\hline Weights Matrix File: & None \\
\hline Selection Set: & False \\
\hline
\end{tabular}




\section{Appendix 4 Model \#1}

Regression output. Dependent Variable: Total Price

\begin{tabular}{|c|c|c|c|}
\hline Variable & $\begin{array}{c}\text { Coefficient } \\
\text { Estimates }\end{array}$ & Variable & Coefficient Estimates \\
\hline Mineral Rights & $\begin{array}{l}22671.86 \\
(15729.3)\end{array}$ & Ritchie & $\begin{array}{c}-6578.10 \\
(46172.28) \\
\end{array}$ \\
\hline $\begin{array}{l}\text { Appraised Building } \\
\text { Value }\end{array}$ & $\begin{array}{c}1.36 \\
(.099) * * *\end{array}$ & Taylor & $\begin{array}{l}42861.75 \\
(77639.07)\end{array}$ \\
\hline Home site & $\begin{array}{l}7831.17 \\
(9216.67)\end{array}$ & Tyler & $\begin{array}{l}-27779.49 \\
(55332.02)\end{array}$ \\
\hline Crops & $\begin{array}{c}817.09 \\
(371.46)^{* *}\end{array}$ & Wetzel & $\begin{array}{l}-12168.53 \\
(59004.26)\end{array}$ \\
\hline Pasture & $\begin{array}{c}1170.62 \\
(251.65) * * * \\
\end{array}$ & Wood & $\begin{array}{l}-28106.98 \\
(50154.54)\end{array}$ \\
\hline Forest & $\begin{array}{c}824.29 \\
(148.90) * * * \\
\end{array}$ & Slope & $\begin{array}{c}-873.06 \\
(1046.90) \\
\end{array}$ \\
\hline Other & $\begin{array}{c}754.95 \\
(1222.95) \\
\end{array}$ & $\begin{array}{l}\text { Distance to town under } \\
5 \mathrm{k}\end{array}$ & $\begin{array}{c}2773.62 \\
(3705.35) \\
\end{array}$ \\
\hline Barbour & $\begin{array}{l}40422.94 \\
(84016.29)\end{array}$ & $\begin{array}{l}\text { Distance to town } \\
\text { between } 5 \& 10 \mathrm{k}\end{array}$ & $\begin{array}{l}-538.39 \\
(1629.15)\end{array}$ \\
\hline Brooke & $\begin{array}{l}35698.38 \\
(55072.96) \\
\end{array}$ & $\begin{array}{c}\text { Distance to town } \\
\text { between } 10 \& 25 \mathrm{k}\end{array}$ & $\begin{array}{l}-1487.71 \\
(1863.62)\end{array}$ \\
\hline Doddridge & $\begin{array}{l}83758.53 \\
(53234.23)\end{array}$ & $\begin{array}{c}\text { Distance to town of } 25 \\
\mathrm{k} \text { and greater }\end{array}$ & $\begin{array}{l}-941.80 \\
(1484.79)\end{array}$ \\
\hline Hancock & $\begin{array}{c}-9392.34 \\
(64036.39)\end{array}$ & Distance to K 12 & $\begin{array}{l}-3340.18 \\
(4333.54)\end{array}$ \\
\hline Harrison & $\begin{array}{l}97519.31 \\
(65975.27)\end{array}$ & Distance to Interstate & $\begin{array}{l}329.70 \\
(1798.61) \\
\end{array}$ \\
\hline Marion & $\begin{array}{c}24274.18 \\
(63202.57)\end{array}$ & Distance to US route & $\begin{array}{l}-571.32 \\
(2154.87)\end{array}$ \\
\hline Marshall & $\begin{array}{l}-922.15 \\
(62247.5)\end{array}$ & $\begin{array}{c}\text { Distance to Active } \\
\text { Mine }\end{array}$ & $\begin{array}{c}3403.10 \\
(1916.13) *\end{array}$ \\
\hline Monongalia & $\begin{array}{c}8404.75 \\
(77026.82)\end{array}$ & $\begin{array}{l}\text { Distance to Wind } \\
\text { Turbine }\end{array}$ & $\begin{array}{c}158.06 \\
(1195.50)\end{array}$ \\
\hline Ohio & $\begin{array}{l}56966.16 \\
(65921.25) \\
\end{array}$ & $\begin{array}{c}\text { Distance to Oil \& Gas } \\
\text { wells }\end{array}$ & $\begin{array}{l}10553.67 \\
(7231.89) \\
\end{array}$ \\
\hline Pleasants & 0 & Distance to Streams & $\begin{array}{c}109171.4 \\
(59649.36) *\end{array}$ \\
\hline Preston & $\begin{array}{c}70242.39 \\
(80878.31) \\
\end{array}$ & Constant & $\begin{array}{l}22456.66 \\
(98435.2) \\
\end{array}$ \\
\hline \multicolumn{4}{|l|}{$\begin{array}{l}\text { F- statistic }= \\
7.89\end{array}$} \\
\hline Adj R R & $\mathbf{0 . 5 2}$ & & \\
\hline $\mathbf{N}$ & 311 & & \\
\hline
\end{tabular}

Values in parentheses denote Standard errors. Statistical significances denoted as: $10 \%(*), 5 \%(* *)$, and $1 \%(* * *)$. 
Appendix 5. Model \# 2 Regression output. Dependent Variable: Total Price

\begin{tabular}{|c|c|c|c|c|}
\hline Source & SS $\quad d f$ & MS & & $\begin{array}{c}\text { Number of obs }=311 \\
F(16,294)=21.36\end{array}$ \\
\hline Model & & & & \\
\hline $\begin{array}{l}2.9018 \mathrm{e}+12 \\
\text { Residual }\end{array}$ & $161.8136 \mathrm{e}+11$ & Prob $>$ F & $=0.0000$ & \\
\hline $2.4960 \mathrm{e}+12$ & $2948.4899 e+09$ & R-squared & $=0.54$ & Adj R-squared = 0.512 \\
\hline $\begin{array}{l}\text { Total } \\
5.3978 e+12\end{array}$ & $3101.7412 e+10$ & Root MSE & $=92141$ & \\
\hline
\end{tabular}

\begin{tabular}{|c|c|c|c|c|c|}
\hline price & Coef. & Std. Err. $\quad \mathrm{t}$ & \multicolumn{3}{|c|}{ P>t $\quad[95 \%$ Conf. Interval] } \\
\hline percentcrop & -208.084 & $292.765 \quad-0.71$ & 0.478 & -784.265 & 368.098 \\
\hline percentpast & -27.629 & $228.064 \quad-0.12$ & 0.904 & -476.474 & 421.216 \\
\hline appraised & 1.375 & $.0908 \quad 15.15$ & 0.000 & 1.196 & 1.55 \\
\hline mracres & 275.871 & $143.761 \quad 1.92$ & 0.056 & -7.061 & 558.804 \\
\hline acres & 864.08 & $118.099 \quad 7.32$ & 0.000 & 631.653 & 1096.506 \\
\hline slope & -1217.648 & $955.585-1.27$ & 0.204 & -3098.301 & 663.006 \\
\hline dis2town5n10k & 367.993 & $858.711 \quad 0.43$ & 0.669 & -1322.006 & 2057.992 \\
\hline dtwn10n25k & -1830.035 & $924.605-1.98$ & 0.049 & -3649.718 & -10.351 \\
\hline dtwn25k & 1202.32 & 814.058 & 0.141 & -399.8 & 2804.439 \\
\hline dist2k12 & -2027.129 & $3143.046-0.64$ & 0.519 & -8212.851 & 4158.592 \\
\hline d2interst & -2301.847 & 1149.603 & 0.046 & -4564.342 & -39.352 \\
\hline d2usroute & -1461.379 & 1566.416 & 0.352 & -4544.189 & 1621.431 \\
\hline activminep & 2984.302 & $1453.867 \quad 2.05$ & 0.041 & 122.997 & 5845.607 \\
\hline $\mathrm{d} 2$ windtirb & -529.17 & $399.934 \quad-1.32$ & 0.187 & -1316.267 & 257.928 \\
\hline oilgaswell & 11421.11 & $5800.179 \quad 1.97$ & 0.050 & 5.980 & 22836.24 \\
\hline dis2strem & 117025.4 & 57940.45 & 0.044 & 2994.756 & 231056 \\
\hline _cons & 90016.43 & 32573.56 & 0.006 & 25909.52 & 154123.3 \\
\hline
\end{tabular}




\section{Appendix 6. Model \#3 Regression output. Dependent Variable: log Price}

\begin{tabular}{|llcc|}
\hline Source SS & df MS & Numof obs $=311$ & \\
& & & \\
Model & 16 & Prob F $=0.0000$ & \\
85.7588617 & 5.35992885 & R-squared $=$ & \\
Residual & 294 & 0.4546 & \\
102.885496 & .349950668 & & Adj R-squared $=$ \\
& & & 0.4249 \\
& & & \\
\hline
\end{tabular}

\begin{tabular}{|c|c|c|c|c|}
\hline Inprice & Coef. & Std. Err. $\quad t$ & $\mathrm{P}>\mathrm{t}$ & [95\% Conf. Interval] \\
\hline percentcrop & -0.001 & $.0019-0.66$ & 0.509 & $\begin{array}{ll}-.005 \quad .002 \\
\end{array}$ \\
\hline percentpast & -0.0008 & $\begin{array}{ll}.001 & -0.53\end{array}$ & 0.598 & $\begin{array}{ll}-.004 \quad .002 \\
\end{array}$ \\
\hline appraised & $7.59 \mathrm{E}-06$ & $\begin{array}{c}5.83 \mathrm{e}-07 \\
13.02\end{array}$ & 0 & $6.44 \mathrm{e}-06 \quad 8.73 \mathrm{e}-06$ \\
\hline mracres & 0.001 & $\begin{array}{ll}.0009 & 1.54\end{array}$ & 0.124 & -.0003 \\
\hline acres & 0.004 & $.0008 \quad 5.44$ & 0 & $\begin{array}{ll}.003 & .007\end{array}$ \\
\hline slope & -0.005 & $\begin{array}{ll}.006 & -0.85\end{array}$ & 0.397 & $\begin{array}{ll}.017 & .009\end{array}$ \\
\hline dis2town $5 \mathrm{n} 10 \mathrm{k}$ & 0.003 & $.006 \quad 0.69$ & 0.489 & $\begin{array}{ll}-.007 & .015\end{array}$ \\
\hline dtwn10n25k & -0.01 & $\begin{array}{ll}.006 & -1.66\end{array}$ & 0.098 & $-.022 \quad .002$ \\
\hline dtwn25k & 0.008 & $.005 \quad 1.56$ & 0.121 & $\begin{array}{ll}-.002 \quad .018\end{array}$ \\
\hline dist $2 \mathrm{k} 12$ & -0.006 & $\begin{array}{ll}.020 & -0.28\end{array}$ & 0.779 & $\begin{array}{ll}-.045 \quad .034 \\
\end{array}$ \\
\hline d2interst & -0.015 & $\begin{array}{ll}.007 & -1.97\end{array}$ & 0.05 & $\begin{array}{ll}-.029 & .000\end{array}$ \\
\hline d2usroute & -0.012 & $.010-1.17$ & 0.245 & -.032 \\
\hline activminep & 0.016 & $\begin{array}{ll}.009 & 1.71\end{array}$ & 0.089 & $-.002 \quad .034$ \\
\hline $\mathrm{d} 2$ windtirb & -0.002 & $\begin{array}{ll}.003 & -0.86\end{array}$ & 0.39 & $\begin{array}{ll}-.007 & .003\end{array}$ \\
\hline oilgaswell & 0.047 & $.037 \quad 1.26$ & 0.208 & $-.026 \quad .120$ \\
\hline dis2strem & 1.02 & 2.74 & 0.006 & 1.752 \\
\hline _cons & 11.284 & $\begin{array}{ll}.209 & 53.96\end{array}$ & 0 & 10.87 \\
\hline
\end{tabular}




\section{Appendix 7. Model \# 4 Regression output. Dependent Variable: log Price}

\begin{tabular}{|lllll} 
Source & SS df & MS & Number of obs $=311$ \\
Model 62.1026401 & 163.88141501 & $\begin{array}{l}\text { Prob }>F=0.0000 \\
\text { R-squared }=0.33\end{array}$ \\
Residual 126.541718 294) $=9.02$ & \\
& 294.430414006 & $\begin{array}{l}\text { Adj R-squared }=0.292 \\
\text { Total 188.644358 }\end{array}$ & 310.608530187 & Root MSE $=.656$
\end{tabular}

\begin{tabular}{|c|c|c|c|c|c|}
\hline Inprice & Coef. & Std. Err. & $\mathrm{t}$ & $\mathrm{P}>\mathrm{t} \quad[95$ & $\%$ Conf. Interval \\
\hline percentcrop & -0.003 & .0021 & -1.28 & 0.203 & $\begin{array}{ll}-.007 .001 \\
\end{array}$ \\
\hline percentpast & -0.0007 & .0016 & -0.41 & 0.685 & $\begin{array}{l}-.004 .003 \\
\end{array}$ \\
\hline Inappraised & 0.080 & .009 & 9.17 & 0.000 & .063 .098 \\
\hline mracres & 0.002 & .001 & 1.81 & 0.072 & -.0001 .004 \\
\hline Inacres & 0.366 & .071 & 5.13 & 0.000 & .226 .506 \\
\hline slope & -0.007 & .007 & -1.01 & 0.311 & $\begin{array}{ll}-.020 \quad .006 \\
\end{array}$ \\
\hline dis2town5n10k & 0.003 & .006 & 0.46 & 0.642 & $\begin{array}{ll}-.009 & .015\end{array}$ \\
\hline dtwn10n25k & -0.017 & .007 & -2.49 & 0.013 & $-.03-.003$ \\
\hline dtwn25k & 0.005 & .006 & 0.83 & 0.410 & -.007.016 \\
\hline dist2k12 & -0.021 & .022 & -0.93 & 0.353 & $\begin{array}{ll}-.065 & .023 \\
\end{array}$ \\
\hline d2interst & -0.011 & .008 & -1.28 & 0.201 & -.027.006 \\
\hline d2usroute & -0.009 & .011 & -0.84 & 0.403 & $-.031 \quad .013$ \\
\hline activminep & 0.021 & .010 & 2.02 & 0.044 & .0005 .041 \\
\hline d2windtirb & -0.001 & .003 & -0.52 & 0.600 & $-.007 \quad .004$ \\
\hline oilgaswell & 0.027 & .041 & 0.65 & 0.515 & $\begin{array}{ll}-.054 & .08\end{array}$ \\
\hline dis2strem & 1.331 & .415 & 3.21 & 0.001 & $.514 \quad 2.148$ \\
\hline _cons & 9.913 & .358 & 27.68 & 0.000 & $9.208 \quad 10.617$ \\
\hline
\end{tabular}




\section{Appendix 8. Model \#5 Regression output. Dependent Variable: Price per acre}

\begin{tabular}{|c|c|c|c|c|}
\hline Source & SS df & MS & & $\begin{array}{c}\text { Number of obs }=311 \\
F(16,294)=21.33\end{array}$ \\
\hline Model $1.4304 \mathrm{e}+09$ & 1689398446.4 & Prob $>$ F & $=0.0000$ & \\
\hline Residual $1.2319 \mathrm{e}+09$ & 2944190256.39 & R-squared & $=0.5373$ & \\
\hline & & & & Adj R-squared $=0.5121$ \\
\hline Total $2.6623 e+09$ & 3108588098.46 & Root MSE & $=2047$ & \\
\hline
\end{tabular}

\begin{tabular}{|c|c|c|c|c|c|}
\hline priceperacre & Coef. & Std. Err. & $\mathrm{t}$ & \multicolumn{2}{|c|}{$\begin{array}{cc}\mathrm{P}>\mathrm{t} \quad[95 \% \text { Conf. } \\
\text { Interval }]\end{array}$} \\
\hline percentcrop & -1.934 & 6.494 & -0.30 & 0.766 & $\begin{array}{ll}-14.715 & 10.847 \\
\end{array}$ \\
\hline percentpast & 1.935 & 5.044 & 0.38 & 0.701 & $-7.992 \quad 11.863$ \\
\hline appraised & 0.030 & .00201 & 14.87 & 0.000 & $.0260 \quad .034$ \\
\hline $\mathbf{m r}$ & 484.186 & 322.278 & 1.50 & 0.134 & $-150.079 \quad 1118.45$ \\
\hline acres & -17.098 & 2.394 & -7.14 & 0.000 & $-21.810-12.387$ \\
\hline slope & -36.248 & 21.222 & -1.71 & 0.089 & $-78.015 \quad 5.5184$ \\
\hline dis2town $5 \mathrm{n} 10 \mathrm{k}$ & -16.048 & 19.113 & -0.84 & 0.402 & $\begin{array}{ll}-53.665 & 21.569\end{array}$ \\
\hline dtwn10n25k & -43.850 & 20.831 & -2.11 & 0.036 & $\begin{array}{ll}-84.847 & -2.853 \\
\end{array}$ \\
\hline dtwn $25 \mathrm{k}$ & 8.664 & 18.156 & 0.48 & 0.634 & $\begin{array}{ll}-27.069 & 44.397 \\
\end{array}$ \\
\hline dist2k12 & -51.002 & 69.734 & -0.73 & 0.465 & $-188.244 \quad 86.239$ \\
\hline d2interst & -27.550 & 25.642 & -1.07 & 0.284 & $-78.014 \quad 22.914$ \\
\hline d2usroute & -52.497 & 34.825 & -1.51 & 0.133 & $-121.034 \quad 16.041$ \\
\hline activminep & 80.593 & 32.491 & 2.48 & 0.014 & $16.648 \quad 144.539$ \\
\hline $\mathrm{d} 2$ windtirb & -7.1568 & 8.9142 & -0.80 & 0.423 & $\begin{array}{ll}-24.701 & 10.387 \\
\end{array}$ \\
\hline oilgaswell & 89.935 & 129.211 & 0.70 & 0.487 & $-164.360 \quad 344.23$ \\
\hline dis2strem & 2956.245 & 1287.452 & 2.30 & 0.022 & 422.4565490 .034 \\
\hline _cons & 4166.1 & 719.922 & 5.79 & 0.0 & 5582.953 \\
\hline
\end{tabular}


Appendix 9. Model \# 6 Regression output. Dependent Variable: log Price per acre

\begin{tabular}{|c|c|c|}
\hline SS $\quad d f$ & MS & Number of obs $=311$ \\
\hline & & $F(16,294)=17.85$ \\
\hline Model 109.814003 & 166.86337517 & Prob $>F=0.0000$ \\
\hline $\begin{array}{l}\text { Residual } \\
113.074213\end{array}$ & 294.384606165 & R-squared $=0.4927$ \\
\hline & & Adj R-squared $=0.4651$ \\
\hline Total 222.888215 & 310.718994243 & Root MSE \\
\hline
\end{tabular}

\begin{tabular}{|c|c|c|c|}
\hline Inpriceperacre & Coef. & Std. Err. & $\begin{array}{c}\text { P>t } \quad[95 \% \text { Conf. } \\
\text { Interval] }\end{array}$ \\
\hline percentcrop & -0.002 & $.002-0.94$ & $\begin{array}{lll}0.350 & -.006 & .002\end{array}$ \\
\hline percentpast & -0.001 & $.002 \quad-0.34$ & $\begin{array}{lll}0.736 & -.004 & .002 \\
\end{array}$ \\
\hline appraisedpera e & 0.0003 & .0000212 .44 & $\begin{array}{lll}0.000 & .0003 & .0004 \\
\end{array}$ \\
\hline $\mathrm{mr}$ & 0.184 & $.098 \quad 1.89$ & $\begin{array}{lll}0.060 & -.008 & .3762235\end{array}$ \\
\hline acres & -0.004 & $.0007 \quad-4.99$ & $\begin{array}{lll}0.000 & -.005 & -.002\end{array}$ \\
\hline slope & -0.01 & $.006-0.79$ & $\begin{array}{lll}0.432 & -.018 & .008\end{array}$ \\
\hline dis2town5n10k & 0.003 & $.006 \quad 0.44$ & $\begin{array}{lll}0.660 & -.009 & .014\end{array}$ \\
\hline dtwn10n25k & -0.013 & $.006-2.00$ & $\begin{array}{llll}0.047 & -.0254 & -.0002\end{array}$ \\
\hline dtwn25k & 0.009 & $.006 \quad 1.57$ & $\begin{array}{lll}0.118 & -.002 & .020\end{array}$ \\
\hline dist2k12 & -0.02 & $.021-0.74$ & $\begin{array}{lll}0.462 & -.057 & .026\end{array}$ \\
\hline d2interst & -0.013 & $.008-1.64$ & $\begin{array}{llll}0.101 & -.028 & .003 \\
\end{array}$ \\
\hline d2usroute & -0.012 & $.011-1.14$ & $\begin{array}{lll}0.254 & -.033 & .009\end{array}$ \\
\hline activminep & 0.019 & .010 & $0.059-.0007$ \\
\hline d2windtirb & -0.003 & $.003-0.97$ & $\begin{array}{lll}0.334 & -.008 & .003\end{array}$ \\
\hline oilgaswell & 0.044 & .0391 .12 & $0.263 \quad-.033 .121$ \\
\hline dis2strem & 0.82 & 2.10 & 0.036 \\
\hline _cons & 7.904 & $.219466 \quad 36.01$ & 7.4728 .336 \\
\hline
\end{tabular}




\section{Appendix 10. The Six models side by side (excluding M1)}

\begin{tabular}{|c|c|c|c|c|c|c|}
\hline Variables & $\begin{array}{l}\text { Price } \\
\text { (M2) }\end{array}$ & $\begin{array}{c}\text { Lnprice } \\
\text { (M3 ) }\end{array}$ & $\begin{array}{c}\text { Lnprice } \\
\text { (M4)) }\end{array}$ & $\begin{array}{c}\text { Priceperacre } \\
\text { (M5) }\end{array}$ & $\begin{array}{c}\text { Lnpriceperacre } \\
\text { (M6 ) }\end{array}$ & $\begin{array}{c}\text { Lnpriceperace } \\
\text { (M7) }\end{array}$ \\
\hline Percentcrop & $\begin{array}{c}-208.084 \\
(293)\end{array}$ & $\begin{array}{l}.0012 \\
(0.002)\end{array}$ & $\begin{array}{l}-0.003 \\
(0.002) \\
\end{array}$ & $\begin{array}{c}-1.93 \\
(6.5) \\
\end{array}$ & $\begin{array}{c}-0.002 \\
(0.002) \\
\end{array}$ & $\begin{array}{l}-0.002 \\
(0.002)\end{array}$ \\
\hline Percentpast & $\begin{array}{c}-27.629 \\
(228) \\
\end{array}$ & $\begin{array}{l}-.0007 \\
(0.001) \\
\end{array}$ & $\begin{array}{l}-0.0007 \\
(0.001) \\
\end{array}$ & $\begin{array}{l}1.935 \\
(5.59) \\
\end{array}$ & $\begin{array}{l}-0.0005 \\
(0.002) \\
\end{array}$ & $\begin{array}{l}-0.0004 \\
(0.002) \\
\end{array}$ \\
\hline Lnappraised & & & $\begin{array}{c}0.081 * * * \\
(0.009)\end{array}$ & & & \\
\hline MRAcres & $\begin{array}{l}275.872 \\
(143.71) \\
\end{array}$ & $\begin{array}{c}0.0014 \\
(0.0008)^{*} \\
\end{array}$ & $\begin{array}{l}0.002 * \\
(0.001) \\
\end{array}$ & & & \\
\hline Lnacres & & & $\begin{array}{c}0.366 * * * \\
(0.07)\end{array}$ & & & $\begin{array}{c}-0.514 \\
(0.076)^{* * *}\end{array}$ \\
\hline slope & $\begin{array}{c}-1217.650 \\
(955.58) \\
\end{array}$ & $\begin{array}{l}-0.005 \\
(0.006) \\
\end{array}$ & $\begin{array}{l}-0.007 \\
(0.07) \\
\end{array}$ & $\begin{array}{c}-36.248 \\
(20.304)^{*} \\
\end{array}$ & $\begin{array}{l}-0.005 \\
(0.006) \\
\end{array}$ & $\begin{array}{l}-0.007 \\
(0.01) \\
\end{array}$ \\
\hline Dis2town $5 \sim 10 \mathrm{k}$ & $\begin{array}{l}367.9928 \\
(858.71) \\
\end{array}$ & $\begin{array}{c}0.004 \\
(0.005) \\
\end{array}$ & $\begin{array}{c}0.003 \\
(0.006) \\
\end{array}$ & $\begin{array}{c}-16.048 \\
(17.89) \\
\end{array}$ & $\begin{array}{l}0.003 \\
(0.01) \\
\end{array}$ & $\begin{array}{l}0.003 \\
(0.01) \\
\end{array}$ \\
\hline Distwn10 25k & $\begin{array}{c}-1830.035 \\
(924.6) \\
\end{array}$ & $\begin{array}{c}-0.010 \\
(0.0053)^{*} \\
\end{array}$ & $\begin{array}{c}-0.017 * * \\
(0.007) \\
\end{array}$ & $\begin{array}{c}-43.850 \\
(18.254)^{* *} \\
\end{array}$ & $\begin{array}{c}-0.013 \\
(0.006)^{* *} \\
\end{array}$ & $\begin{array}{c}-0.0178 \\
(0.006) * * * \\
\end{array}$ \\
\hline Distwn $>25 \mathrm{k}$ & $\begin{array}{l}1202.32 \\
(814.05)\end{array}$ & $\begin{array}{c}0.008 \\
(0.005)^{*}\end{array}$ & $\begin{array}{r}0.005 \\
(0.005) \\
\end{array}$ & $\begin{array}{c}8.664 \\
(18.22)\end{array}$ & $\begin{array}{l}0.007 \\
(0.01)\end{array}$ & $\begin{array}{l}0.004 \\
(0.01)\end{array}$ \\
\hline Dist2k12 & $\begin{array}{l}-2027.129 \\
(3143.04) \\
\end{array}$ & $\begin{array}{l}-0.006 \\
(0.02) \\
\end{array}$ & $\begin{array}{l}-0.021 \\
(0.022) \\
\end{array}$ & $\begin{array}{r}-51.002 \\
(57.84) \\
\end{array}$ & $\begin{array}{r}-0.016 \\
(0.02) \\
\end{array}$ & $\begin{array}{r}-0.022 \\
(0.02) \\
\end{array}$ \\
\hline Dis2interst & $\begin{array}{l}-2301.847 \\
(1149.6)^{* *} \\
\end{array}$ & $\begin{array}{c}-0.015 \\
(0.007)^{* *} \\
\end{array}$ & $\begin{array}{r}-0.011 \\
(0.08) \\
\end{array}$ & $\begin{array}{l}-27.550 \\
(25.45) \\
\end{array}$ & $\begin{array}{l}-0.013 \\
(0.01) \\
\end{array}$ & $\begin{array}{l}-0.009 \\
(0.01) \\
\end{array}$ \\
\hline Dis2USroute & $\begin{array}{r}-1461.379 \\
(1566.41) \\
\end{array}$ & $\begin{array}{l}-0.012 \\
(0.01) \\
\end{array}$ & $\begin{array}{r}-0.009 \\
(0.01) \\
\end{array}$ & $\begin{array}{l}-52.500 \\
(33.16) \\
\end{array}$ & $\begin{array}{l}-0.012 \\
(0.01) \\
\end{array}$ & $\begin{array}{r}-0.009 \\
(0.01) \\
\end{array}$ \\
\hline Activemining & $\begin{array}{c}2984.302 \\
(1453.86) * *\end{array}$ & $\begin{array}{c}0.016 \\
(0.009)^{*}\end{array}$ & $\begin{array}{l}0.021 * * \\
(0.010)\end{array}$ & $\begin{array}{c}80.593 \\
(37.393)^{* *}\end{array}$ & $\begin{array}{c}.0187 \\
(0.01)^{*}\end{array}$ & $\begin{array}{c}0.022 \\
(0.010) * *\end{array}$ \\
\hline Dis2Windturb & $\begin{array}{l}-529.170 \\
(399.93)\end{array}$ & $\begin{array}{l}-0.002 \\
(0.002)\end{array}$ & $\begin{array}{l}-0.001 \\
(0.002)\end{array}$ & $\begin{array}{c}-7.157 \\
58 \\
(8.71) \\
\end{array}$ & $\begin{array}{c}-0.003 \\
0\end{array}$ & $\begin{array}{l}-0.002 \\
(0.003)\end{array}$ \\
\hline OilGaswell & $\begin{array}{c}11421.11 \\
(5800.179)^{*} \\
\end{array}$ & $\begin{array}{l}0.047 \\
(0.04) \\
\end{array}$ & $\begin{array}{l}0.027 \\
(0.04) \\
\end{array}$ & $\begin{array}{c}89.935 \\
(108.34) \\
\end{array}$ & $\begin{array}{c}.044 \\
(0.04) \\
\end{array}$ & $\begin{array}{l}0.032 \\
(0.04) \\
\end{array}$ \\
\hline Dis2Stream & $\begin{array}{c}117025.4 \\
(57940.45)^{* *} \\
\end{array}$ & $\begin{array}{c}1.020 \\
(0.41)^{* *} \\
\end{array}$ & $\begin{array}{c}1.331 * * * \\
(0.42) \\
\end{array}$ & $\begin{array}{c}2956.245 \\
(1387.52)^{* *}\end{array}$ & $\begin{array}{c}.820 \\
(0.39)^{* *} \\
\end{array}$ & $\begin{array}{c}1.325 \\
(0.47)^{* * *} \\
\end{array}$ \\
\hline Constant & $\begin{array}{c}90016.43 \\
(32573.56)^{* * *} \\
\end{array}$ & $\begin{array}{c}11.284 \\
(0.20) * * *\end{array}$ & $\begin{array}{c}9.913 * * * \\
(0.36) \\
\end{array}$ & $\begin{array}{c}4166.1 \\
(784.677)^{* * * *} \\
\end{array}$ & $\begin{array}{c}7.904 \\
(0.22)^{* * *} \\
\end{array}$ & $\begin{array}{c}9.762 \\
(0.330)^{* * * *} \\
\end{array}$ \\
\hline Acres & $\begin{array}{c}864.080 \\
(118.09)^{* * *} \\
\end{array}$ & $\begin{array}{c}0.004 \\
(0.000)^{* * *} \\
\end{array}$ & & $\begin{array}{c}-17.098 \\
(3.007)^{* * *} \\
\end{array}$ & $\begin{array}{c}-0.004 \\
(0.001)^{* * *} \\
\end{array}$ & \\
\hline MR & & & & $\begin{array}{l}484.186 \\
(374.99) \\
\end{array}$ & $\begin{array}{c}0.184 \\
(0.10)^{*} \\
\end{array}$ & $\begin{array}{c}0.165 \\
(0.09)^{*} \\
\end{array}$ \\
\hline Lnappraisedperacre & & & & & & $\begin{array}{c}0.080 \\
(0.009)^{* * *} \\
\end{array}$ \\
\hline Appraised & $\begin{array}{l}1.374898 \\
(0.09)^{* * * *} \\
\end{array}$ & $\begin{array}{c}7.59 \mathrm{e}-06 \\
(0.000) * * * \\
\end{array}$ & & $\begin{array}{c}0.0300 \\
(0.004)^{* * *} \\
\end{array}$ & & \\
\hline appraisedpera $\sim$ e & & & & & $\begin{array}{c}0.0003 \\
(0.00002)^{* * *} \\
\end{array}$ & \\
\hline F-Statistics & 14.64 & 15.32 & 17.14 & 7.63 & 17.85 & 14.38 \\
\hline $\begin{array}{c}\text { Adj } R^{2} \\
N\end{array}$ & $\begin{array}{l}0.51 \\
311\end{array}$ & $\begin{array}{l}0.42 \\
311\end{array}$ & $\begin{array}{l}0.29 \\
311\end{array}$ & $\begin{array}{l}0.51 \\
311\end{array}$ & $\begin{array}{c}0.47 \\
311\end{array}$ & $\begin{array}{l}0.40 \\
311\end{array}$ \\
\hline
\end{tabular}

Values in parentheses denote Standard errors. Statistical significances denoted as: $10 \%(*), 5 \%(* *)$, and $1 \%(* * *)$. 


\section{Appendix 11. The significant variables in Model \#4 and Model \#7}

\begin{tabular}{|c|c|c|}
\hline Variables & $\begin{array}{c}\text { Lnprice } \\
\text { (M4)) }\end{array}$ & $\begin{array}{c}\text { Lnpriceperace } \\
\text { (M7) } \\
\end{array}$ \\
\hline \multicolumn{3}{|l|}{ Percentcrop } \\
\hline \multicolumn{3}{|l|}{ Percentpast } \\
\hline Lnappraised & $\begin{array}{c}0.0807226^{* * * *} \\
(0.009)\end{array}$ & \\
\hline MRAcres & $\begin{array}{c}0.0017803^{*} \\
(0.001)\end{array}$ & \\
\hline Lnacres & $\begin{array}{c}0.366076^{* * * *} \\
(0.07)\end{array}$ & $(0.07)^{* * *}$ \\
\hline \multicolumn{3}{|l|}{ slope } \\
\hline \multicolumn{3}{|l|}{ Dis2town 5 10k } \\
\hline Distwn10 25k & $\begin{array}{c}-0.016525 * * \\
(0.007) \\
\end{array}$ & $(0.006)^{* * *}$ \\
\hline \multicolumn{3}{|l|}{ Distwn $>25 \mathrm{k}$} \\
\hline \multicolumn{3}{|l|}{ Dist2k12 } \\
\hline \multicolumn{3}{|l|}{ Dis2interst } \\
\hline \multicolumn{3}{|l|}{ Dis2USroute } \\
\hline Activemining & $\begin{array}{c}0.0208809^{* * *} \\
(0.010) \\
\end{array}$ & $(0.010)^{* *}$ \\
\hline \multicolumn{3}{|l|}{ Dis2Windturb } \\
\hline \multicolumn{3}{|l|}{ OilGaswell } \\
\hline Dis2Stream & $\begin{array}{c}1.331395^{* * * *} \\
(0.42)\end{array}$ & $(0.47)^{* * *}$ \\
\hline Constant & $\begin{array}{c}9.91261 * * * \\
(0.36)\end{array}$ & $(0.330)^{* * *}$ \\
\hline \multicolumn{3}{|l|}{ Acres } \\
\hline MR & & $(0.09)^{*}$ \\
\hline Lnappraisedperacre & & $(0.009)^{* * *}$ \\
\hline \multicolumn{3}{|l|}{ Appraised } \\
\hline \multicolumn{3}{|l|}{ appraisedpera $\sim \mathrm{e}$} \\
\hline $\mathrm{P}-\mathrm{V}$ & 0 & 0 \\
\hline R2/adj R2 & 0.33 & 0.43 \\
\hline $\mathrm{N}$ & 311 & 311 \\
\hline
\end{tabular}

Values in parentheses denote Standard errors. Statistical significances denoted as: $10 \%(*), 5 \%(* *)$, and $1 \%(* * *)$. 
Appendix 12. The Study of model \#7

Appendix 12.1. Regression output for Model \#7. . Dependent Variable: log Price per acre

\begin{tabular}{|llll|}
\hline Source SS df & MS & Number of obs $=311$ \\
Model 96.0466019 & & F( 16, 294) $=13.91$ \\
Residual 126.841613 & 16.00291262 & Prob $>$ F $=0.0000$ \\
& 294.431434059 & R-squared $=0.4309$ \\
Total 222.888215 & & Adj R-squared $=0.3999$ \\
\hline
\end{tabular}

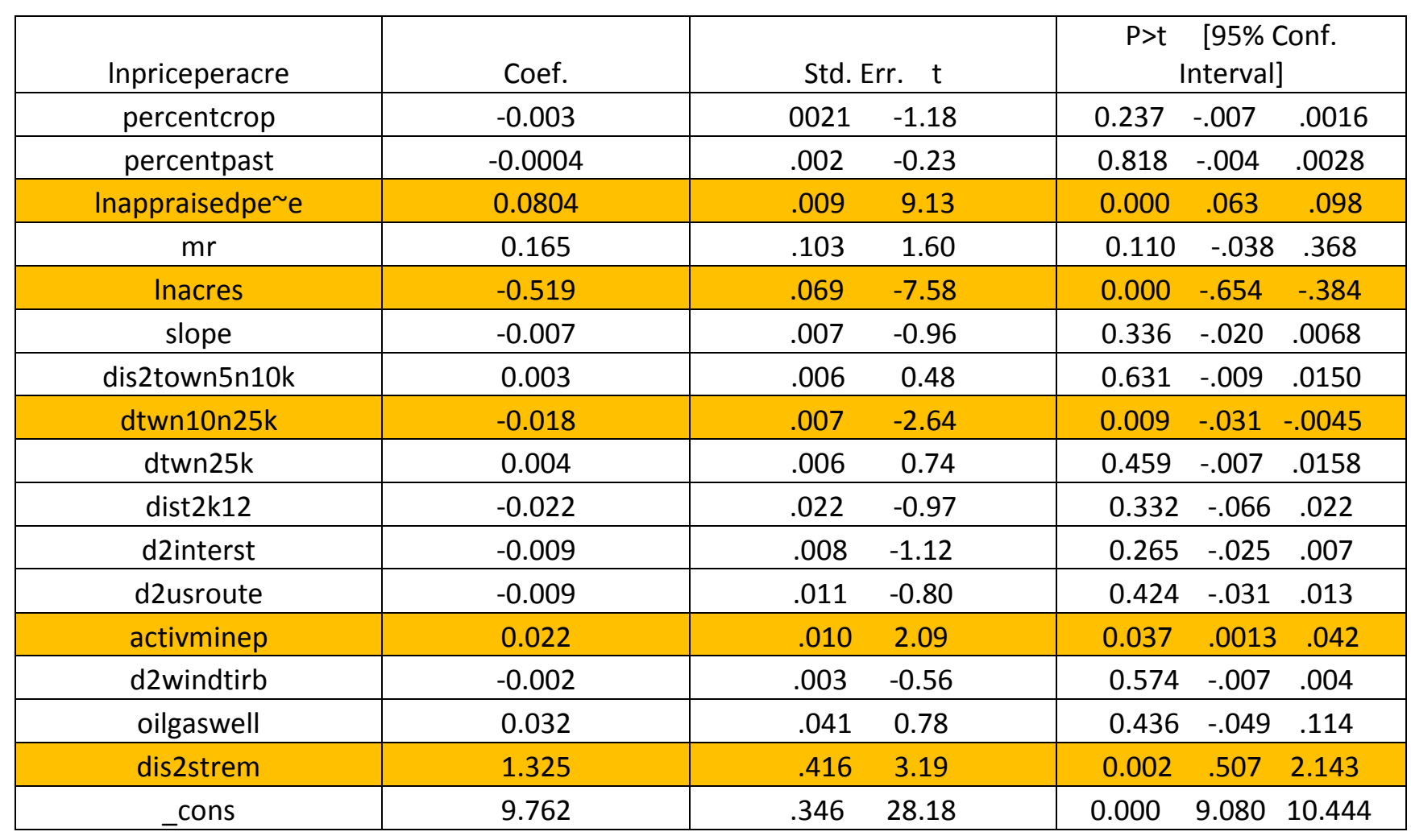




\section{Appendix 12.2.}

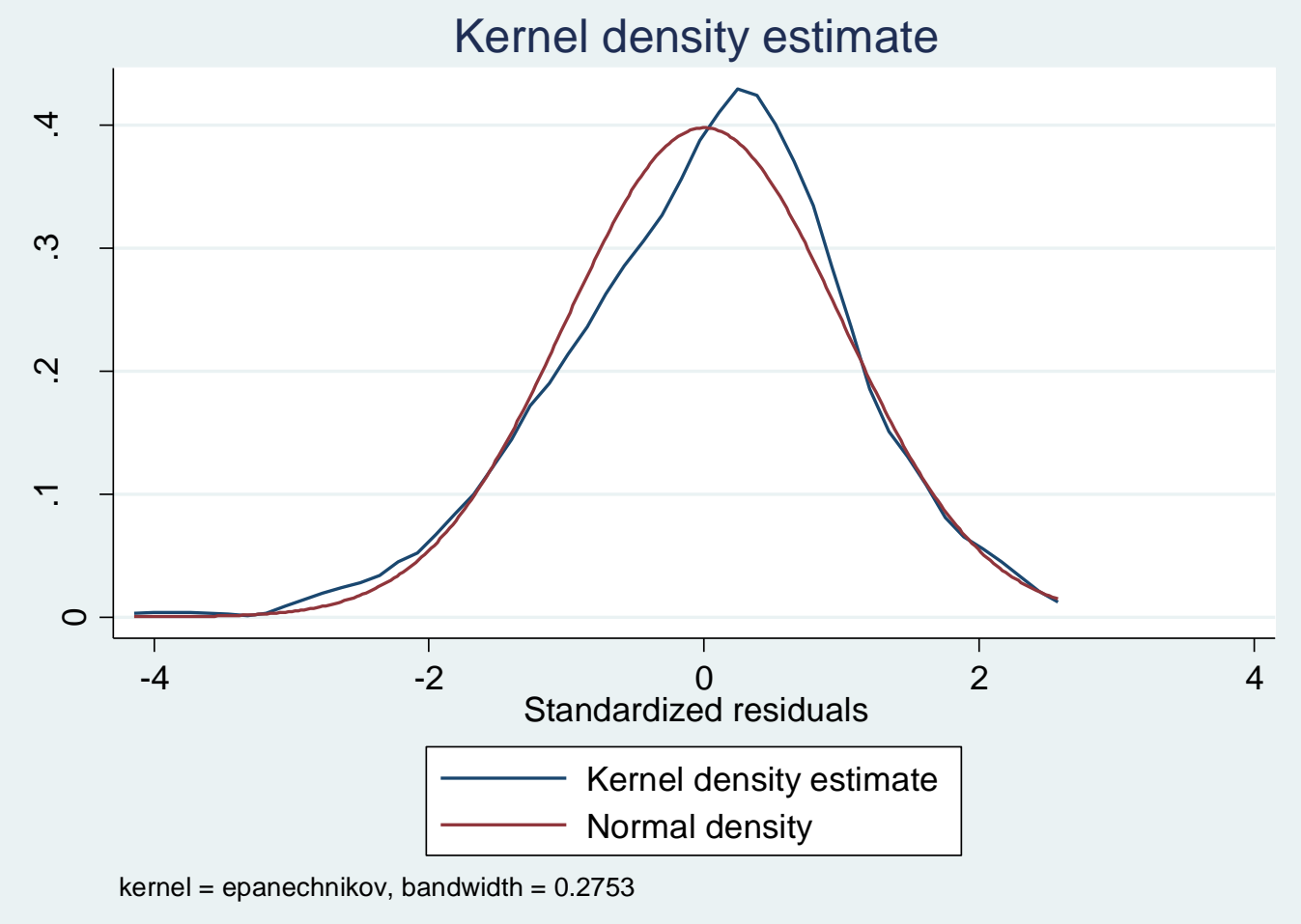




\section{Appendix 12.3. Potential Outliers}

For normalized residual squared

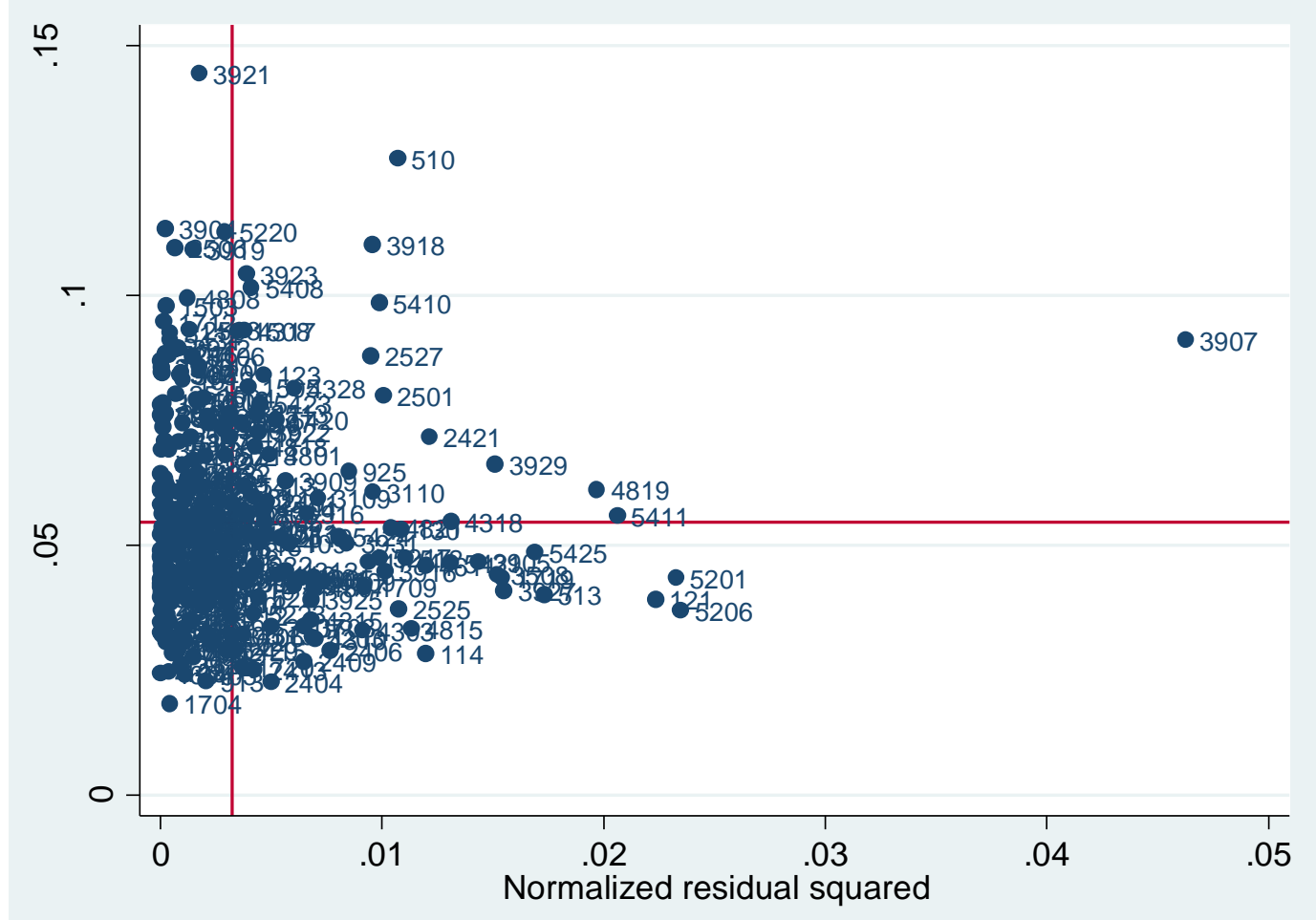




\section{Appendix 12.4.}

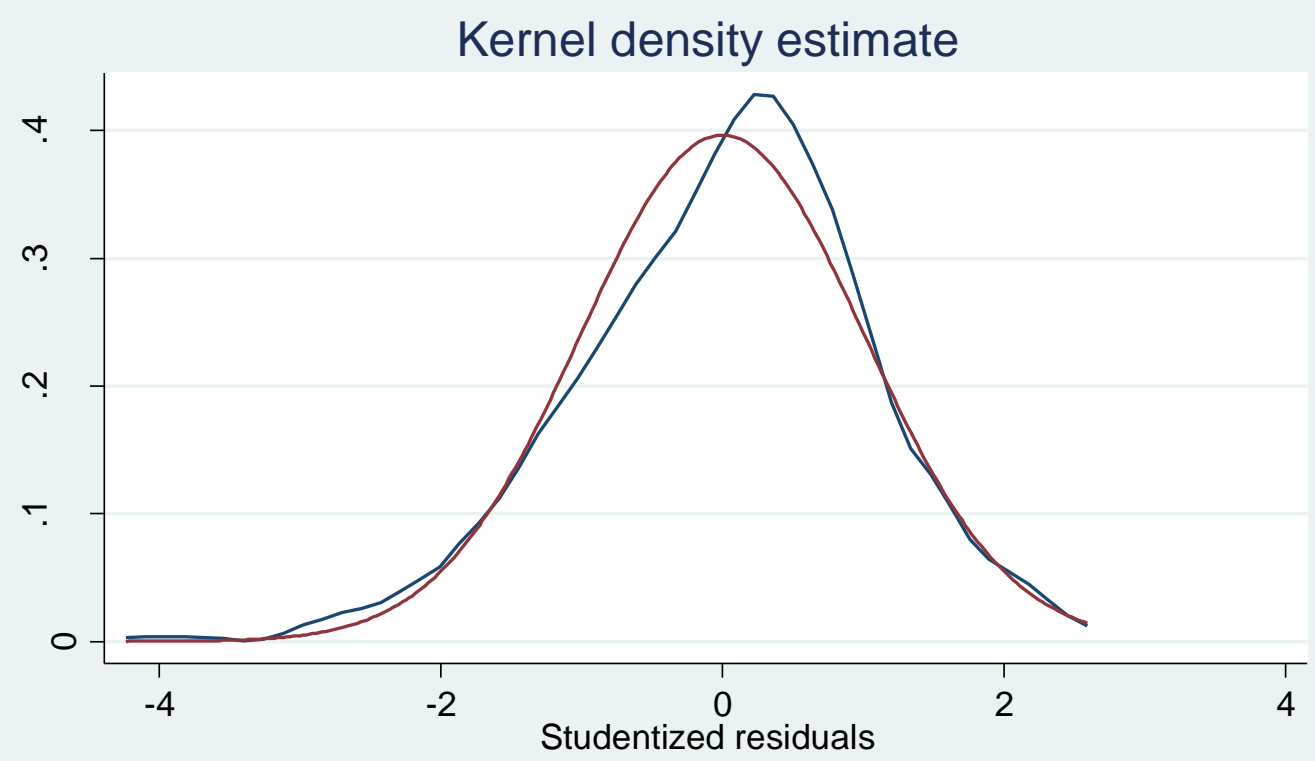

Kernel density estimate Normal density

kernel $=$ epanechnikov, bandwidth $=0.2750$ 


\section{Appendix 12.5}

Stem-and-leaf plot for ti (Studentized residuals)

ti rounded to nearest multiple of .01

plot in units of .01

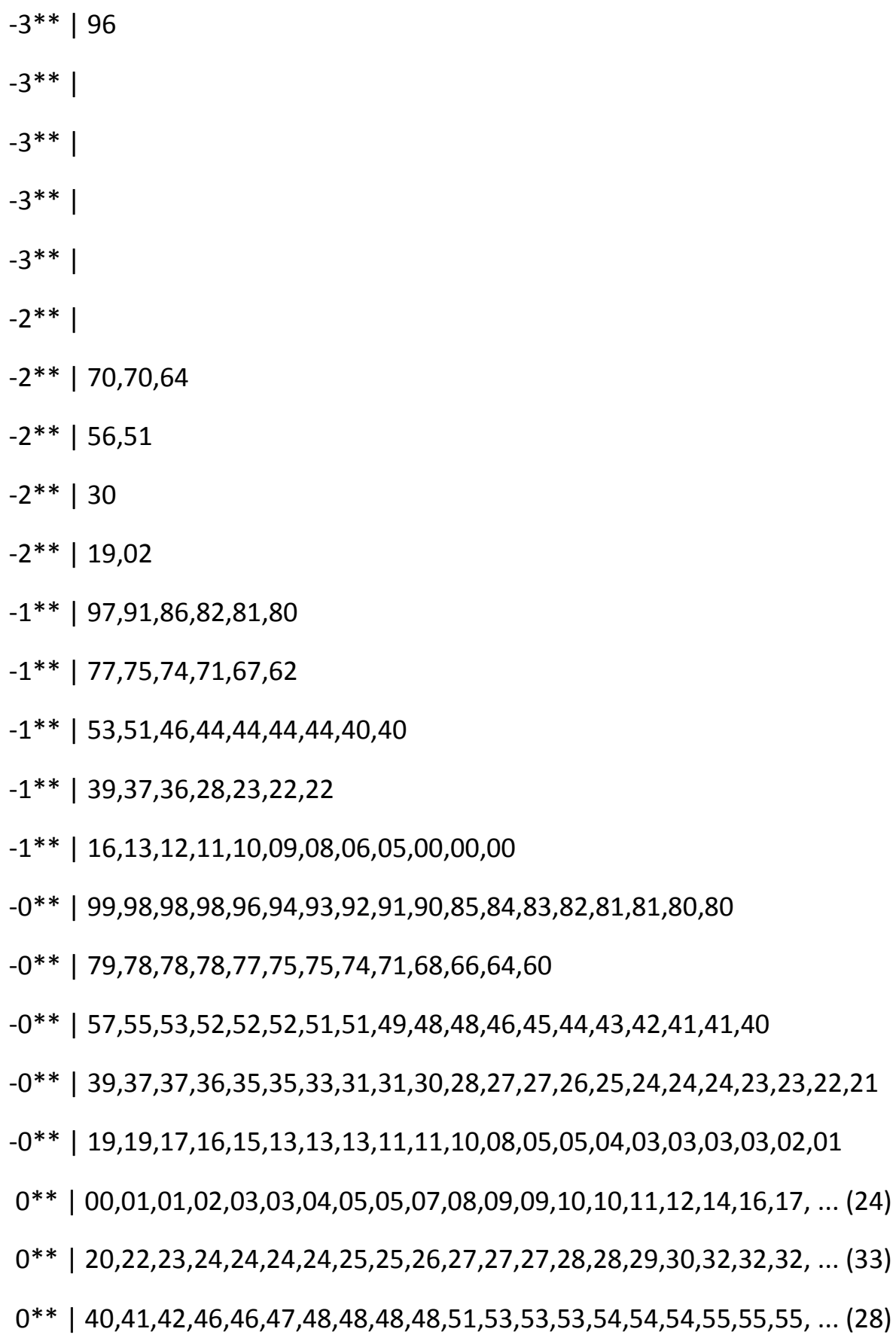




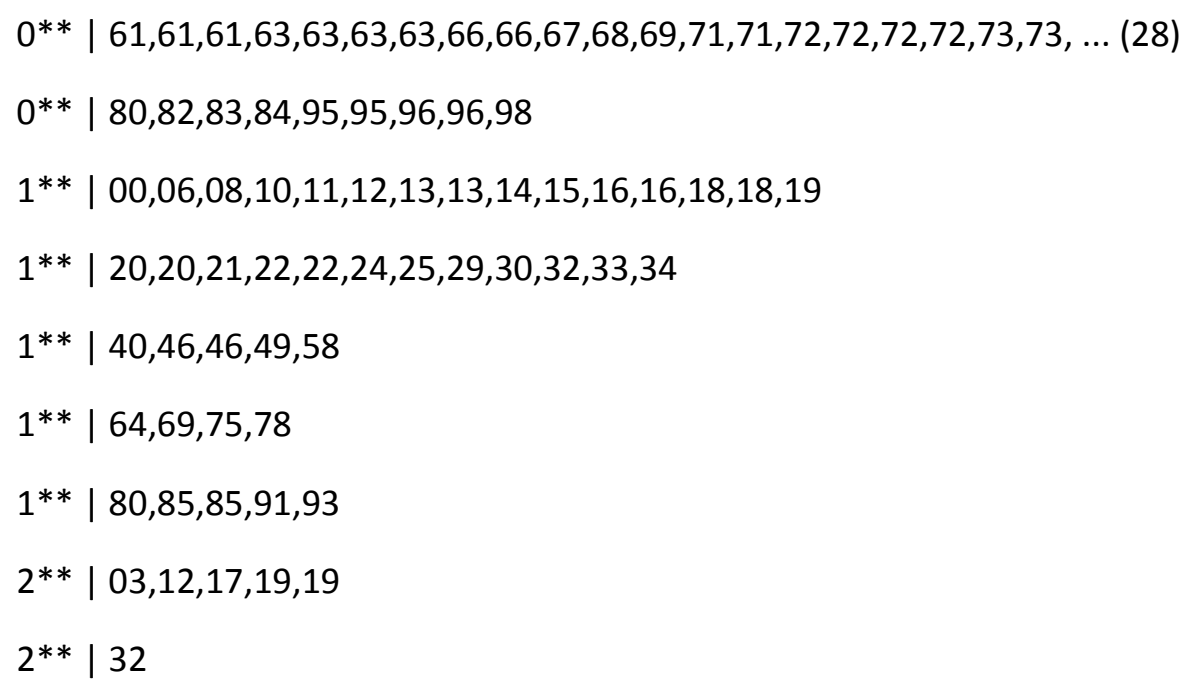

\begin{tabular}{|c|c|}
\hline Code & ti \\
\hline 3907 & -3.964 \\
\hline 5206 & -2.705 \\
\hline 5201 & -2.703 \\
\hline 121 & -2.641 \\
\hline 5411 & -2.557 \\
\hline 4819 & -2.506 \\
\hline 5425 & -2.301 \\
\hline 3927 & -2.193 \\
\hline 5421 & -2.018 \\
\hline 4318 & 2.029 \\
\hline 3905 & 2.116 \\
\hline 3508 & 2.175 \\
\hline 1719 & 2.190 \\
\hline 3929 & 2.194 \\
\hline 513 & 2.319 \\
\hline
\end{tabular}


Appendix 12.6. Vif: Checking for Multicollinearity

\begin{tabular}{|c|c|c|}
\hline Variable & VIF & $1 / \mathrm{VIF}$ \\
\hline d2interst & 3.95 & 0.253 \\
\hline activminep & 3.65 & 0.274 \\
\hline $\mathrm{d} 2$ windtirb & 3.48 & 0.2874 \\
\hline dtwn25k & 3.37 & 0.297 \\
\hline dtwn10n25k & 2.8 & 0.357 \\
\hline d2usroute & 1.68 & 0.595 \\
\hline dis2town 10k & 1.67 & 0.597 \\
\hline dist2k12 & 1.46 & 0.683 \\
\hline oilgaswell & 1.34 & 0.747 \\
\hline percentcrop & 1.24 & 0.808 \\
\hline dis2strem & 1.18 & 0.844 \\
\hline Inacres & 1.17 & 0.853 \\
\hline percentpast & 1.16 & 0.865 \\
\hline slope & 1.1 & 0.909 \\
\hline Inappraise ${ }^{\sim}$ & 1.09 & 0.916 \\
\hline $\mathrm{mr}$ & 1.07 & 0.934 \\
\hline Mean VIF & 1.96 & \\
\hline
\end{tabular}


Appendix 12.7. Specification error (model misspecification)

\begin{tabular}{|lccccc|}
\hline Source & SS & df & MS & Number of obs $=$ & 311 \\
& & & & $F(2,308)$ & 120.02 \\
Model & & 97.6224722 & 248.8112361 & Prob $>$ F & 0 \\
Residual & & 125.265743 & 308.406706958 & R-squared & 0.438 \\
& & & & Adj R-squared & 0.4343 \\
Total & & & & Root MSE & 0.63774 \\
\hline
\end{tabular}

\begin{tabular}{|c|c|c|c|c|}
\hline Inpriceperacre & Coefficents. & Std. Err. & P>t $\quad[95 \%$ Conf. & Interval] \\
\hline _hat & -1.550 & $1.230-1.19$ & $0.233-4.100$ & 1.002 \\
\hline hatsq & 0.166 & $\begin{array}{ll}.085 & 1.97 \\
\end{array}$ & .00006 & 0.332 \\
\hline _cons & 9.694 & 4.951 & $0.051-.0470$ & 19.436 \\
\hline
\end{tabular}

Ramsey RESET test using powers of the fitted values of Inpriceperacre

Ho: model has no omitted variables

$$
\begin{aligned}
& F(3,291)=1.52 \\
& \text { Prob }>F=0.2101
\end{aligned}
$$

\section{Correctly Specified.}


Appendix 12.8. Checking Homoscedasticity of Residuals

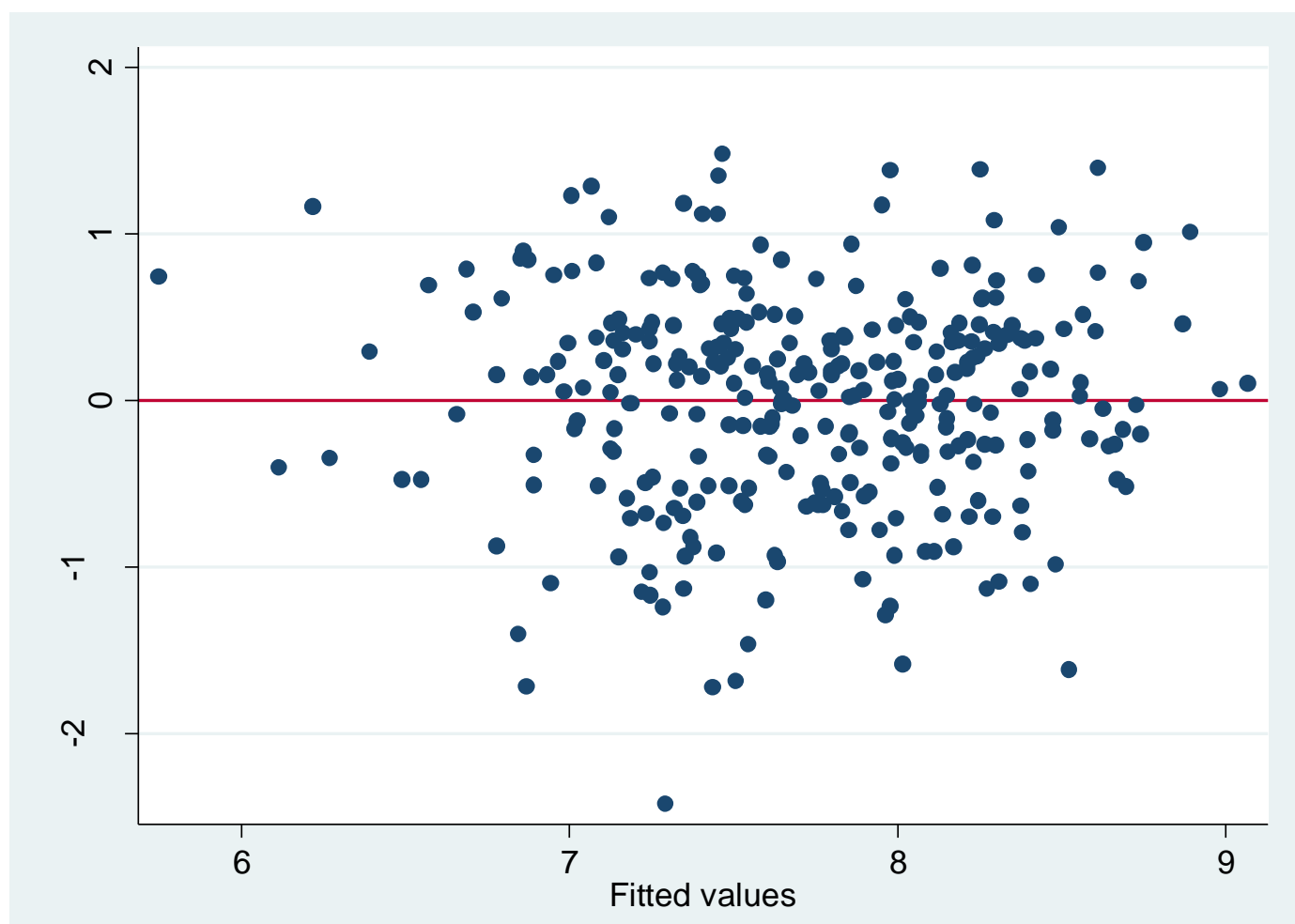

Breusch-Pagan / Cook-Weisberg test for heteroskedasticity

Ho: Constant variance

Variables: fitted values of Inpriceperacre

$$
\begin{aligned}
& \operatorname{chi2}(1)=4.19 \\
& \text { Prob }>\text { chi2 }=0.0406
\end{aligned}
$$

HetroSkedastic 
Appendix 12.9. The Robust regression output for mode \#7.

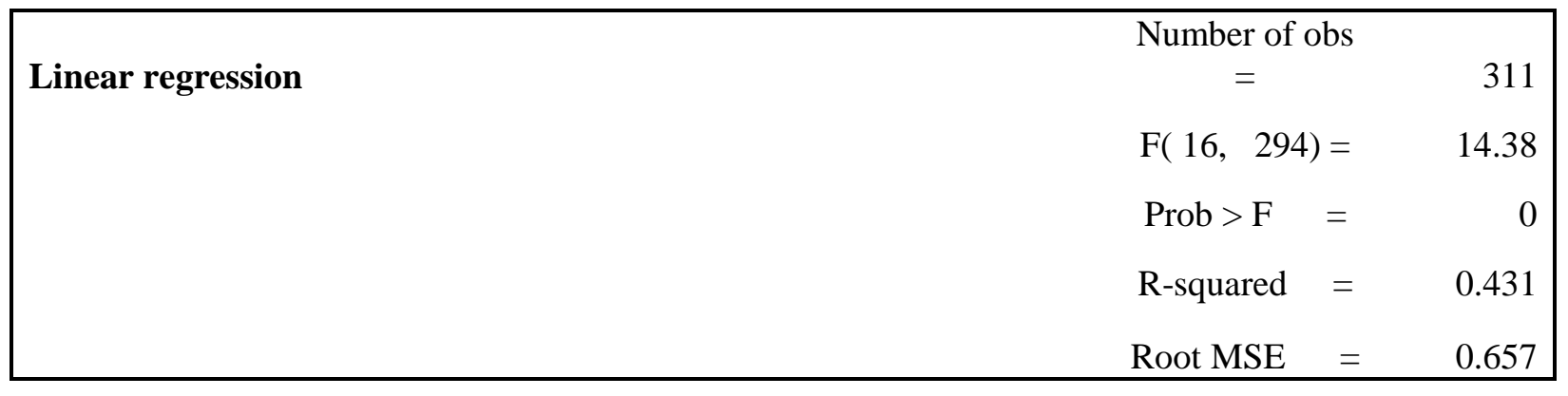

\begin{tabular}{|c|c|c|c|c|c|}
\hline & & Robust & & & \\
\hline lnpriceperacre & Coefficients. & Std. Err. & $\mathrm{t}$ & $\begin{array}{c}\mathrm{P}>\mathrm{t} \quad[95 \% \\
\text { Conf. }\end{array}$ & Interval] \\
\hline percentcrop & -0.002 & 0.002 & -1.04 & $\begin{array}{ll}0.298 & -.007 \\
\end{array}$ & 0.002 \\
\hline percentpast & -0.0004 & 0.002 & -0.24 & $\begin{array}{ll}0.810 & -.003 \\
\end{array}$ & 0.003 \\
\hline lnappraisedpe e & 0.080 & 0.009 & 8.91 & $0.000 \quad .063$ & 0.098 \\
\hline $\mathrm{mr}$ & 0.165 & 0.090 & 1.84 & $\begin{array}{ll}0.066 & -.011 \\
\end{array}$ & 0.341 \\
\hline lnacres & -0.519 & 0.070 & -7.53 & $0.000 \quad-.655$ & -0.383 \\
\hline slope & -0.007 & 0.007 & -1.01 & $\begin{array}{ll}0.314 & -.019 \\
\end{array}$ & 0.006 \\
\hline dis 2 town $5 \mathrm{n} 10 \mathrm{k}$ & 0.003 & 0.006 & 0.48 & $\begin{array}{ll}0.629 & -.009 \\
\end{array}$ & 0.015 \\
\hline dtwn10n25k & -0.018 & 0.006 & -2.81 & $0.005 \quad-.030$ & -0.005 \\
\hline dtwn $25 \mathrm{k}$ & 0.004 & 0.005 & 0.8 & $0.422 \quad-.006$ & 0.015 \\
\hline dist2k12 & -0.022 & 0.022 & -0.99 & $\begin{array}{ll}0.321 & -.065 \\
\end{array}$ & 0.021 \\
\hline d2interst & -0.009 & 0.008 & -1.16 & $\begin{array}{ll}0.247 & -.025 \\
\end{array}$ & 0.006 \\
\hline d2usroute & -0.009 & 0.012 & -0.73 & $\begin{array}{ll}0.466 & -.033 \\
\end{array}$ & 0.015 \\
\hline activminep & 0.022 & 0.0102 & 2.13 & 0.034 & 0.042 \\
\hline $\mathrm{d} 2$ windtirb & -0.002 & 0.003 & -0.6 & $\begin{array}{ll}0.551 & -.007 \\
\end{array}$ & 0.004 \\
\hline oilgaswell & 0.032 & 0.041 & 0.79 & $\begin{array}{ll}0.428 & -.0478 \\
\end{array}$ & 0.112 \\
\hline dis2strem & 1.325 & 0.456 & 2.9 & 0.004 & 2.223 \\
\hline ccons & 9.762 & 0.330 & 29.57 & 0.000 & 10.412 \\
\hline
\end{tabular}

